Universidade de São Paulo

Escola dE COMUNICAÇÕES E ARTES

Programa de Pós-Graduação em Música

José Pereira de Mattos Neto

\title{
A muitas vozes: \\ composição como encontro
}

São Paulo 

José Pereira de Mattos Neto

\section{A muitas vozes: composição como encontro}

Dissertação de Mestrado apresentada ao Programa de PósGraduação em Música da Escola de Comunicações e Artes da Universidade de São Paulo, como exigência parcial para a obtenção do título de Mestre em Música. Área de concentração: Processos de Criação Musical. Subárea: Sonologia

Orientador: Silvio Ferraz Mello Filho

São Paulo 
Autorizo a reprodução e divulgação total ou parcial deste trabalho, por qualquer meio convencional ou eletrônico, para fins de estudo e pesquisa, desde que citada a fonte.

Catalogação na Publicação

Serviço de Biblioteca e Documentação

Escola de Comunicações e Artes da Universidade de São Paulo

Dados inseridos pelo(a) autor(a)

Mattos Neto, José Pereira de

A muitas vozes: composição como encontro / José Pereira de Mattos Neto; orientador, Silvio Ferraz. -- São Paulo, 2020.

124 p.: il.

Dissertação (Mestrado) - Programa de Pós-Graduação em Música

- Escola de Comunicações e Artes / Universidade de São Paulo.

Bibliografia

Versão original

1. composição 2. voz 3. pesquisa artística I. Ferraz, Silvio II. Título.

CDD 21. ed. -780 
MATTOS NETO, José Pereira de. A muitas vozes: composição como encontro. 2020.

124p. Dissertação de Mestrado - Programa de Pós-Graduação em Música, Escola de Comunicações e Artes, Universidade de São Paulo, São Paulo, 2020.

Aprovado em:

\section{Banca examinadora}

Prof. Dr.: $\quad$ Silvio Ferraz Mello Filho

Instituição: Departamento de Música, Escola de Comunicações e Artes,

Universidade de São Paulo

Julgamento:

Profa. Dra.: Paula Maria Aristides de Oliveira Molinari

Instituição: Universidade Federal do Maranhão, campus São Bernardo

Julgamento:

Profa. Dra.: Ledice Fernandes de Oliveira

Instituição: Académie de Musique et Danse de la CCMP, AMD, França

Julgamento: 

a Isadora e a Sueli

pela poesia

pelo sonho

pela vida 



\section{Agradecimentos}

Agradeço a minha mãe, Sueli, pelo apoio e pela paciência tanto em 2019, com os preparativos da residência artística, como principalmente em 2020 , durante a quarentena da pandemia de Covid-19. Por me ajudar a não desistir.

Agradeço a Isadora Borges, companheira e amiga, pelo amor e carinho, pela poesia, por se lançar junto comigo na areia quente de uma duna, sem saber o que vai acontecer. Pelos encontros e pelos sonhos.

Agradeço a Silvio Ferraz, orientador e professor, por sempre abrir portas e janelas na composição e na música, sempre deixar o vento entrar na pesquisa, por sempre abrir um pouco de caos no teto da academia. Agradeço a Paula Molinari, pelo encontro com as muitas vozes da voz, com o lugar da criação e com a pesquisa artística. Pela generosidade imensa de sempre abrir novos entendimentos e escutas.

Agradeço a Jessica Gubert, pela amizade que atravessou cada fase dos nossos mestrados e pela entrega no encontro com esse mirante que continua soprando cada vez mais vasto. Agradeço a Giovanna Airoldi, pela amizade e pela tinta, por topar o que não sabíamos fazer, topar descobrir juntos no encontro de gestos. Agradeço a Alexandre D'Elboux Filho, Bruna Mayer e Paola Ribeiro (além de Isadora), pelo presente de fazer com eles a residência artística de 2019, pelo presente de conhecer suas outras vozes e outros olhares e práticas.

Agradeço a Paulo Rios, Pedro Yugo Sano Mani, Guilherme Ribeiro, Lucia Esteves, Bruna Budri e Tay Cruz pelas muitas conversas sobre composição, criação, arte, vida. Agradeço aos alunos e à professora Pamela Almeida do curso Licenciatura em Linguagens e Códigos/Música da UFMA (campus São Bernardo), pela generosidade na troca, no encontro e nas experiências.

Agradeço a Alice K. Yagyu e a todos os integrantes do Laboratório de Atuação (LAt!), pela poesia dos encontros, das cenas, das propostas, das práticas e das conversas. Agradeço a Wânia Storolli e (novamente) Paula Molinari, e a todos os alunos das disciplinas que cursei no IA-Unesp em 2019, pelo encontro com Cavarero, Artaud, com tantas vozes, com a arte sonora ambiental e com a performance.

Agradeço a Lívia Braga, psicóloga, pelo apoio fundamental nesse período de quarentena devido à pandemia de Covid-19.

Agradeço aos funcionários do Depto. de Música da ECA-USP, do IA-Unesp e do campus São Bernardo da UFMA, por tornarem essa pesquisa viável. E à FAPESP, por torná-la possível. 



\section{RESUMO}

MATTOS NETO, José Pereira de. A muitas vozes: composição como encontro. 2020. 124p. Dissertação de Mestrado - Programa de Pós-Graduação em Música, Escola de Comunicações e Artes, Universidade de São Paulo, São Paulo, 2020.

A composição musical muitas vezes é vista como atividade baseada principalmente na elaboração intelectual de formas de organizar sons e fluxos sonoros. A partir dessa visão, compõe-se para um instrumento ideal, ou mesmo para um instrumentista ideal, com o foco no resultado estético que surge no palco. A presente pesquisa investiga uma prática composicional baseada na unicidade relacional da voz, conceito desenvolvido por Adriana Cavarero, através da ideia de encontro, como elaborada por Gilles Deleuze e Claire Parnet, colocando em jogo práticas e conceitos advindos da música, das artes cênicas, visuais e da performance. A investigação se dá pela metodologia de Pesquisa Artística, como explicada por Marília Velardi e outros, através do relato e discussão de processos criativos desenvolvidos ao longo da pesquisa. Busca-se, assim, uma prática composicional que se funde no encontro de muitas vozes.

Palavras-chave: composição, voz, pesquisa artística. 


\section{Abstract}

MATTOS NETO, José Pereira de. A muitas vozes: composição como encontro. 2020. 124p. Dissertação de Mestrado - Programa de Pós-Graduação em Música, Escola de Comunicações e Artes, Universidade de São Paulo, São Paulo, 2020.

Musical composition often is seen as an activity mostly based in intellectual elaboration of ways to organize sounds and sonic streams. From this point of view, one composes for an ideal instrument, or even for an ideal player, focusing in aesthetic outcomes that arise at stage. This research seeks a compositional practice based on relational unicity, a concept developed by Adriana Cavarero, through the idea of meeting or encounter, as elaborated by Gilles Deleuze and Claire Parnet, combining practices and concepts from music, scenical and visual arts and performance. The investigation follows the Artistic Research methodology, as explained by Marilia Velardi and others, through narrative and discussion of creative processes developed throughout the research. This way, a compositional practice grounded in a meeting of many voices is researched.

Keywords: composition, voice, artistic research. 


\section{LISTA DE FIGURAS}

Figura 1: Primeiro experimento de desenho-escrita da respiração 25

Figura 2: Segundo experimento de desenho-escrita da respiração 27

Figura 3: Quatro tiras de papel de arroz 33

Figura 4: Escrita-desenho-pintura de Alexandre 34

Figura 5: Escrita-desenho-pintura de Isadora 35

Figura 6: Escrita-desenho-pintura de Maryah 35

Figura 7: Minha escrita-desenho-pintura 35

Figura 8: Quatro tiras prontas secam $\quad 37$

Figura 9: Três momentos de Respire no Recital de Conclusão de Curso 39

Figura 10: Primeira parte de Respire no sarau Vozes Inauditas 43

Figura 11: Comunicação do grupo da residência artística aos alunos da UFMA $\quad 51$

Figura 12: Bruna e Alexandre conduzem a primeira parte da oficina 53

Figura 13: Paola conduz a segunda parte da oficina 53

Figura 14: Isadora conduz a terceira parte da oficina $\quad 54$

Figura 15: Conduzo a quarta parte da oficina $\quad 54$

Figura 16: Performance coletiva Respire $\quad 54$

Figura 17: Primeiro manuscrito da peça Mirante 63

Figura 18: Excerto da bula da última partitura de Mirante 69

Figura 19: Primeira página do segundo manuscrito da peça Mirante $\quad 71$

Figura 20: Dois registros do encontro de 10 de maio 73

Figura 21: Trecho do encontro do dia 13 de maio $\quad 74$

Figura 22: Segunda página do segundo manuscrito da peça Mirante 75

Figura 23: Três momentos do exercício da caminhada $\quad 78$

Figura 24: Três momentos depois do exercício da travessia 79

Figura 25: Duas passagens da primeira parte de Mirante $\quad 79$

Figura 26: Primeira página da partitura usada na estreia de Mirante 83

Figura 27: Segunda página da partitura usada na estreia de Mirante $\quad 84$

Figura 28: Registro da estreia de Mirante no Espaço das Artes 86

Figura 29: Jessica grava Mirante em meio à mata da Chapada dos Guimarães $\quad 88$

Figura 30: Partitura gráfica colaborativa $\quad 94$

Figura 31: Duas leituras da partitura da figura $30 \quad 95$

Figura 32: Símbolos gráficos definidos ao longo do processo 96

Figura 33: Giovanna lê a transcrição do áudio de encontro anterior 97

Figura 34: Aquecimentos e primeiro espelho 99

Figura 35: Segundo e terceiro espelhos em quatro momentos 100

Figura 36: Mapa de gestos instrumentais próximos no violoncelo 102

Figura 37: Dois espelhos depois de mudanças nos materiais e símbolos $\quad 104$

Figura 38: Desenhos de fluxos possíveis para a performance 106 
Figura 39: Registro da estreia de Azul no Espaço das Artes 


\section{SUMÁRIO}

1 DE ONDE

2 RESPIRE, OU O BROTAR DAS VOZES NA CRIAÇÃO 23

2.1 Um pequeno experimento 23

2.2 Outras vozes, muitos desdobramentos 24

2.3 A voz da respiração 29

2.4 Do ventre à boca, a unicidade da voz-corpo 31

2.5 O instante e a apneia, abrir o tempo 36

2.6 Traçar no sopro do palco 39

2.7 Das vozes que brotam no vazio $\quad 45$

$\begin{array}{lll}2.8 & \text { O caminho do encontro } & 49\end{array}$

3 MiRANTE, OU UM HORIZONTE A VOZES MUITAS

3.1 Dos ventos que sopram

3.2 A sensação de um horizonte $\quad 60$

3.3 Muitos e vários cantos $\quad 65$

$\begin{array}{lll}3.4 & \text { Movendo o ar } & 68\end{array}$

$\begin{array}{lll}3.5 & \text { Escutar a mata } & 76\end{array}$

3.6 Chamar o mirante $\quad 82$

4 AZUL, OU CRIAR NO REFLEXO DOS GESTOS

4.1 O desenho e o arco 90

4.2 Gestos feitos de tinta 93

$\begin{array}{lll}4.3 & \text { O espelho } & 97\end{array}$

$\begin{array}{lll}4.4 & \text { O progresso emaranhado } & 104\end{array}$

$\begin{array}{lll}4.5 & \text { O espelho, aberto } & 108\end{array}$

4.6 O correr das linhas $\quad 110$

5 UM PEQUENO SOPRO $\quad 115$

$\begin{array}{ll}\text { REFERÊNCIAS } & 119\end{array}$ 


\title{
1 DE ONDE
}

\author{
Kronos foi preso \\ a garganta enforcada \\ e a mão no chicote
}

Este é um trabalho sobre composição musical. Sobre? Que composição?

Antes de tudo, defino agora: falo aqui da composição que tenho experimentado nos últimos anos. Não pretendo criar regras gerais ou abstrações universais; antes, procuro narrar, discutir, refletir, botar em jogo e em relação alguns processos criativos pelos quais passei nesses dois anos de pesquisa de Mestrado - na verdade, um pouco mais até, já que um desses processos vinha de antes de 2019 -, e o faço na esperança de que com isso ajude também a outras pessoas que vivem a criação artística.

Assim, rompo de início com um posicionamento científico mais tradicional, em que eu me excluiria, me isolaria do fenômeno pesquisado. O que quero é pesquisar arte fazendo arte, pesquisar composição compondo. Não me interessa tanto que o foco principal da pesquisa seja a análise das técnicas usadas por outras pessoas para compor; afinal, não quero compor de novo, recompor as peças analisadas. Além do mais, as técnicas composicionais "são sempre comuns. São sempre as técnicas de uma época." (FERRAZ, 2007, p. 3) Não que a análise musical não ajude a criar novas relações; mas de qualquer modo não quero esse enfoque para essa pesquisa. O que me interessa aqui é muito mais o método - ou melhor, métodos. ${ }^{1}$

Não falo do método que busca testar e aplicar conhecimento preexistente para gerar resultados repetíveis por qualquer pessoa - o que poderia ser entendido como método científico. Método, nas artes, não costuma passar por aí, pela repetição impessoal. É justamente seu potencial para uma variabilidade infinita que interessa a quem faz arte, para com isso desenvolver um conhecimento novo. (COESSENS; CRISPIN; DOUGLAS, 2009, p. 12, 53) Falo então dos métodos pelos quais um processo criativo pode ser conduzido. Aliás, métodos, aqui, não seria bem o termo; seria muito mais "processos acabados de experimentação (...) os programas não são manifestos, e menos ainda fantasias, mas meios de orientação para conduzir uma experimentação que ultrapassa nossas capacidades de prever". (DELEUZE; PARNET, 1998, p. 61, grifo dos autores)

Mas esse conhecimento novo que a arte engendra, como falar dele? Diferente de um conhecimento científico verbalizável, o que os processos artísticos desenvolvem é um conhecimento tácito, não verbalizável, já que ele está ligado constitutivamente às

\footnotetext{
${ }^{1}$ Ao longo da dissertação, as referências (bibliográficas, a outras seções, a figuras, a notas de rodapé ou links externos) estão marcadas com fundo cinza, para melhor identificação. Se a leitura acontecer no formato digital, todas essas referências são interativas, basta clicar sobre elas.
} 
criações artísticas; e essa ligação se dá não pelo discurso verbal, mas pelas experiências sensoriais. (CANDY; EDMONDS, 2018, p. 66; VELARDI, 2018, p. 45) E, como nos dizem Gil e Assis (2019, p. 3), falando da arte enquanto pesquisa, "a experiência sensorial como tal pode se constituir como um tipo de conhecimento construído em conjunto, pelo pesquisador e seus interlocutores."

A pesquisa, porém, precisa ser compartilhada e disseminada - e isso não me parece ser característica apenas da pesquisa científica tradicional. Como então disseminar, através da pesquisa, esse conhecimento tácito que a arte cria? Sendo ele baseado na experiência sensorial, uma pesquisa que o aborde poderia então se debruçar sobre a complexidade das experiências específicas, buscando as singularidades humanas envolvidas e uma revalorização da experiência artística em si; em vez de consenso e conformidade, objetivos caros à ciência, as contradições das experiências singulares. (COESSENS; CRISPIN; DOUGLAS, 2009, p. 7, 14-15, 53; VELARDI, 2018, p. 45)

Bem, falo aqui da pesquisa artística ${ }^{3}$, uma abordagem de pesquisa em que a criatividade artística e seus processos inerentes de tomada de decisão são colocados em foco; de fato, a "pesquisa artística pode ser definida como conhecimento do processo da criatividade, não dos seus resultados" ${ }^{4}$. (COESSENS; CRISPIN; DOUGLAS, 2009, p. 24) E, para isso, tal pesquisa abarca o fazer artístico. Ainda assim, não respondi totalmente à pergunta que fiz antes: como falar desse conhecimento?
Nessa perspectiva somos, essencialmente, metodologistas. E para que isso se instaure é preciso que declaremos como nós pensamos, como nos organizamos, como tropeçamos, o que descartamos, como estamos fazendo para investigar e narrar ou comunicar ou trazer à tona aquilo o que investigamos. Contar para as pessoas como estamos fazendo, falar das idas e voltas, performar os diálogos e que estabelecemos, as linhas que traçamos, as malhas que tecemos.
"Por esse caminho a pesquisa É Arte e seria, por assim dizer, uma pesquisa sobre método, sobre como pesquisar nas Artes. Na verdade, fazer pesquisa nessa perspectiva é contar histórias sobre como fizemos a nossa pesquisa. (VELARDI, 2018, p. 52, grifo da autora)

É isso o que busco fazer aqui: contar de alguns dos processos criativos de que participei, pelos quais fui alimentado, e falar também dos textos que li, das ideias que me atravessaram, das linhas múltiplas que se entremearam em cada um dos processos. Esse emaranhado de linhas muitas vezes não é capturável pelo discurso verbal argumentativo; assim, oscilei, na escrita, entre tal discurso e um fluxo mais livre de imagens — um texto mais poético, talvez.

Nesse correr mais livre das palavras, um tipo de poesia em particular se fez muito presente: o haicai (ou haikai, ou ainda haiku). Poema tradicional japonês,

\footnotetext{
2 "la experiencia sensorial como tal puede constituirse como un tipo de conocimiento construido en conjunto, por el investigador y sus interlocutores."

${ }^{3}$ Em inglês, artistic research, às vezes traduzida também como investigação artística.

4 "[A]rtistic research can be defined as knowledge of the process of creativity, not its outcomes."
} 
extremamente curto e conciso, o haicai como forma fixa independente surgiu por volta do século XVI — sendo Matsuo Bashō (1644-1694) e seus companheiros os responsáveis por refiná-lo na segunda metade do século XVII. Até hoje o haicai é praticado, tanto no Japão como ao redor do mundo. (BASHŌ, 2016, p. 5; КATO, 2012, p. 93, 104) Há principalmente duas características desse tipo de poesia que atravessaram a escrita dessa dissertação: sua forma (ou ritmo) e seu tempo.

Um haicai é composto por dezessete sílabas, distribuídas em uma sequência de 5-7-5 sílabas em três versos ${ }^{5}$. Os poemas que escrevi nessa dissertação seguem essa sequência, em sua maioria; porém, ao fazê-los, me atentei muito mais ao ritmo que ao número - descartando da contagem sílabas finais de palavras paroxítonas ou proparoxítonas, por exemplo. Além do mais, essa contagem diz respeito à língua japonesa, profundamente diferente da minha; de modo que o rigor, nesse caso, é mais um impulso criativo que um freio.

Por ser tão condensado, o haicai traz também uma sensação específica do tempo: a ênfase no presente, ou melhor, no aqui-agora. Em Bashō, especialmente, o haicai é a expressão da experiência instantânea. Essa experiência não é
emocional, é sensitiva, é um tipo de sintonia entre o alvo da percepção
(mundo exterior) e o íntimo; surge num instante e se extingue noutro.
(...) Nesses poemas, o tempo está parado. Sem passado, sem futuro, o
mundo todo se resume ao "agora = aqui". (KATO, 2012, p. 101, 104)

Para além de Bashō, o haicai pode também trazer lembranças; mas mesmo elas surgem a partir de uma experiência no presente, e que não se volta para o dia seguinte. Aqui-agora.(KATO, 2012, p. 99, 104) Assim, os poemas dessa dissertação foram escritos quase sempre a partir dessa experiência de parar o tempo - ou de senti-lo em seus instantes. Alguns falam dos processos em que se inserem; outros falam do próprio processo de escrita do texto. Não os explico, para que sejam potência de leitura e não entrave interpretativo ${ }^{6}$.

Não me atrevo a dizer que esses poemas são haicais. Isso exigiria um contato muito mais profundo com essa poesia e outros aspectos da cultura japonesa. De todo modo, alguns deles (e outros que escrevi mas não entraram na dissertação) foram feitos como troca de mensagens com Isadora Borges (citada no capítulo 2), que foi quem me apresentou esse tipo de poesia ${ }^{7}$.

Com essa mescla de abordagens na escrita, busco falar de processos criativos. Mas de quais? Além dos que aqui relato e discuto, passei por vários outros processos criativos

${ }^{5}$ A forma poética que deu origem ao haicai, o haikai-renga (ou haikai no renga) também influenciou minha escrita; nela, o poema contém uma segunda estrofe de dois versos em 7-7 sílabas (com a primeira, 5-7-5-7-7), totalizando 31 sílabas. (BASHŌ, 2016, p. 5)

6 Devo a Valéria Bonafé, que integrou a banca de qualificação desse mestrado, a coragem para colocar os poemas na dissertação sem explicá-los.

7 Vale dizer que o renga, forma poética que se tornaria depois o haikai-renga e por fim haikai, era um poema longo feito por várias pessoas, em que cada uma criava uma estrofe a partir da imediatamente anterior - de certa forma, uma troca de mensagens. (KATO, 2012, p. 91-94) 
entre 2019 e 2020, entre música, artes cênicas e performance; o que me leva a escolher os que aqui estão e não outros?

O encontro. Mais do que qualquer outro aspecto ou característica que pudesse apontar como presente nos processos dessa dissertação, é o encontro, ou existir por encontros, o que talvez ligue tais processos.

\begin{abstract}
Quando se trabalha, a solidão é, inevitavelmente, absoluta. (...) Só que é uma solidão extremamente povoada. Não povoada de sonhos, fantasias ou projetos, mas de encontros. (...) Encontram-se pessoas (e às vezes sem as conhecer nem jamais tê-las visto), mas também movimentos, ideias, acontecimentos, entidades. (...) É isso a dupla captura: (...) alguma coisa que está entre os dois, fora dos dois, e que corre em outra direção. (DELEUZE; PARNET, 1998, p. 14-15)
\end{abstract}

Todos esses processos correram por encontros, e não apenas porque era sempre eu e mais alguém(ns). Encontrar é pegar algo da pessoa, da ideia, do movimento para si, deixar-se manchar por essa cor, deixar-se deformar por esse peso, e manchar e deformar também, para que o processo seja esse entre, entre dois, entre muitos. Para isso, considero importante abrir a escuta, não apenas às palavras ditas ou às particularidades dos sons, mas às vozes que surgem no processo.

Por que voz? Porque ela tem uma potência chave nessa escuta: toda voz é única. Como explico melhor no capítulo 2, toda voz vem de uma garganta única, de um corpo único, e sabemos (sentimos) isso sem nem termos consciência - essa unicidade é ontológica na voz, é constitutiva, como nos fala Adriana Cavarero (2011).

Processos criativos que existem pelos encontros de muitas vozes. Abrir a escuta às vozes das pessoas que encontro não é, necessariamente, compor para voz. Nem sequer compor para alguém. Talvez seja compor com alguém, mas ainda não é isso. O que seria?

No capítulo 2, falo de Respire, um processo que passou por várias remontagens, reconfigurações, reinvenções, e inúmeros encontros, do final de 2017 até 2019. Nele, abordo mais profundamente a necessidade da voz nessa pesquisa, além de um primeiro encontro com as artes visuais e a performance. Já no capítulo 3, figura o processo de Mirante, peça que fiz com Jessica Gubert em 2019 e que segue em processo. Ali, falo também dos encontros com práticas e ideias das artes cênicas, e de suas potências e dificuldades dentro da prática musical. No capítulo 4 , falo do processo de Azul, performance colaborativa com Giovanna Airoldi, de 2019-2020. Além das artes cênicas, surge o encontro mais aprofundado com as artes visuais. E, por fim, na seção 5 , encerro o texto.

Mas essa ordem não é fixa. Há três possibilidades de leitura: a primeira, dada pela sequência do texto. A segunda, começar pelo capítulo 2, ler até o fim da seção 2.5, então saltar e ler os capítulos 3 e 4, depois voltar à seção 2.6 do capítulo 2, lê-lo até seu final, e por fim ler a seção 5 . Essa segunda possibilidade é apontada com referências no texto, nos pontos em que devem ocorrer saltos, de modo que não é preciso voltar para cá para segui-la. 
Outra possibilidade, mais formal e que não me agrada tanto, seria transpor o ritmo do haicai, 5-7-5, para a ordem dos três capítulos principais: ler primeiro o capítulo 3 (6 seções), depois o capítulo 2 (8 seções), depois o capítulo 4 (6 seções). E, claro, terminar com a seção 5 .

Essa dissertação foi integralmente escrita (com exceção de alguns dos seus poemas e alguns trechos desta seção) entre setembro e novembro de 2020, durante o período de quarentena imposto pela pandemia de Covid-19. Isso trouxe diversas dificuldades e entraves à pesquisa, em particular a impossibilidade de conversar livremente, olhos nos olhos, com outras/os pesquisadores-artistas. Em todo caso, foi também um meio de atravessar esse período sem deixar de criar.

Essa pesquisa de Mestrado, assim como a pesquisa de Iniciação Científica ${ }^{8}$ (2017-2018) que a precedeu, foram financiadas pela Fundação de Amparo à Pesquisa do Estado de São Paulo (FAPESP), o que foi essencial, fundamental para sua realização.

8 A pesquisa de Iniciação Científica teve, entre agosto e dezembro de 2016, financiamento do Conselho Nacional de Desenvolvimento Científico e Tecnológico (CNPq). 


\title{
2 RESPIRE, OU O BROTAR DAS VOZES NA CRIAÇÃO
}

\author{
fumaça cobre \\ montanhas e serras longe \\ aqui só o pó
}

Respirar. Coisa simples. Puxo o ar e solto, puxo e solto, lanço o ar ao ar que me cerca. Coisa simples. Mas eu respiro? Onde eu respiro? Coisa simples? Tantos não respiram, tantos não puderam e não podem mais respirar, porque os pulmões se enchem de água, porque as matas estão cheias de fogo, e a fumaça já atravessa os campos, as cidades e as nossas veias. Respirar, simples?

O ar entra, e o corpo já não é o mesmo. O peito se abre, as costelas se abrem, as vértebras abrem um pequeno espaço, e as mil palavras que se me brotam na mente abrem um pequeno espaço. É o ar que entra. Deixar ele entrar, não puxá-lo, mas deixá-lo entrar, tão fino e leve como pode ser, ou tão áspero e denso como ele também pode ser. Não há o que temer dos pulmões que o recebem, do ventre que o recebe. A garganta, esse pequeníssimo abismo entre a cabeça e o peito, por ela corre um vento que desce calmo.

Instante. O corpo pára.

E o ar sai, talvez pelo mesmo caminho, mas nunca da mesma forma, e nunca o mesmo ar, carregado dos calores e tremores de dentro. O abismo, o pequeno abismo da garganta deixa que sopre esse turbilhão de humores que quer sair; não quer, na verdade, ele apenas sai, e com ele os espaços todos se fecham em um vazio momentâneo.

(Escrevo no momento em que o Brasil registra quase 130.000 mortes pela Covid-19. Cento e trinta mil, e eu poderia tecer muitas palavras bonitas a partir da respiração para falar dessas cento e trinta mil mortes, mas cento e trinta mil, sozinhas, já são bem mais do que o suficiente para que entendamos que não é apenas respirar, é muito mais do que apenas respirar. Mas apenas respirar, para cento e trinta mil pessoas, para cento e trinta mil pares de pulmões, cada um diferente dos outros, apenas respirar não foi possível.)

Mas eu respiro? Quando o ar passa por mim, eu o sinto passar? E quando o sinto passar, o que acontece comigo?

\subsection{Um pequeno experimento}

Em dezembro de 2017, portanto há quase três anos, aconteceu uma coisa interessante enquanto escrevia alguns versos: minha respiração ficou truncada, tão interrompida 
que não era possível escrever. A mente corria por mil palavras ao mesmo tempo, mas o corpo quase que não respirava. Não que eu estivesse tendo algum problema respiratório; me parece que era muito mais a ansiedade que interrompia o fluxo do que eu escrevia.

E então me ocorreu uma pequena ideia: escrever a respiração - ou desenhá-la, melhor dizendo. Comecei a registrar no papel o fluxo do ar com uma linha que corria indefinidamente: se o ar entrava, a linha subia; se ele saía, o traço descia. Quando eu ficava em apneia (sem inspirar nem expirar), fosse com muito ou pouquíssimo ar nos pulmões - quando o ar não corria - a linha seguia reta, ou suspendia seu traço apenas percorrendo com o olhar uma linha do tempo no papel. A figura 1 mostra o resultado desse exercício. E aos poucos a respiração foi recuperando seu fluxo, um correr um pouco diferente de um riacho tranquilo e sereno: tão logo a mão registra no papel o movimento do ar, o ar também começa a registrar a mão.

E se um traço interessante aparece, por que não segui-lo? Curvar o ar, aumentar o peso do traço, tornar o ar tão fino como um fio de cabelo no papel, deslizar na ins- e expiração. Entrecortar, ampliar, esvaziar o sopro, seguir calmo na apneia flutuante dos pulmões cheios, ou vivo e desperto no vazio angustiante do corpo sem ar. Brincar de correr o ar e as mãos por caminhos não cotidianos.

$$
\begin{aligned}
& \text { escrever-fluxo } \\
& \text { a mão que curva e segue } \\
& \text { o ar que em mim passeia }
\end{aligned}
$$

E a brincadeira com a respiração não termina com a sua escrita-desenho; depois que o traço é feito, ele pode ser lido. Como? Se o traço sobe, o ar entra; se desce, sai; se se mantém reto ou há apenas vazio no papel, apneia. Naquela primeira vez, em dezembro de 2017, logo depois de desenhar-escrever por quatro páginas, comecei a lêlas, seguidamente, várias vezes, inclusive continuando os versos que havia começado antes do experimento, escrevendo sobre a linha. E o efeito da escrita-desenho foi sendo amplificado pela leitura; a respiração se tornando cada vez menos cotidiana.

A partir de um esvaziamento e de um corpo não-cotidiano, algo pode acontecer (BROOK, 2000; OIDA, 2007). Ao longo de 2018, o vazio e o não-cotidiano, trazidos pela respiração alterada pela sua escrita-desenho-leitura, possibilitou que eu encontrasse um meio de criar no tempo.

\subsection{Outras vozes, muitos desdobramentos}

Escrever ou desenhar a respiração. Ler esse traço com o ar. De lá para cá, esse pequeno exercício se multiplicou e atravessou alguns processos.

Por exemplo, no processo da peça Beira-mar (abril a junho de 2018), escrever e alongar o tempo da respiração de Raphael Caserta (tubista), para que uma sensação de 

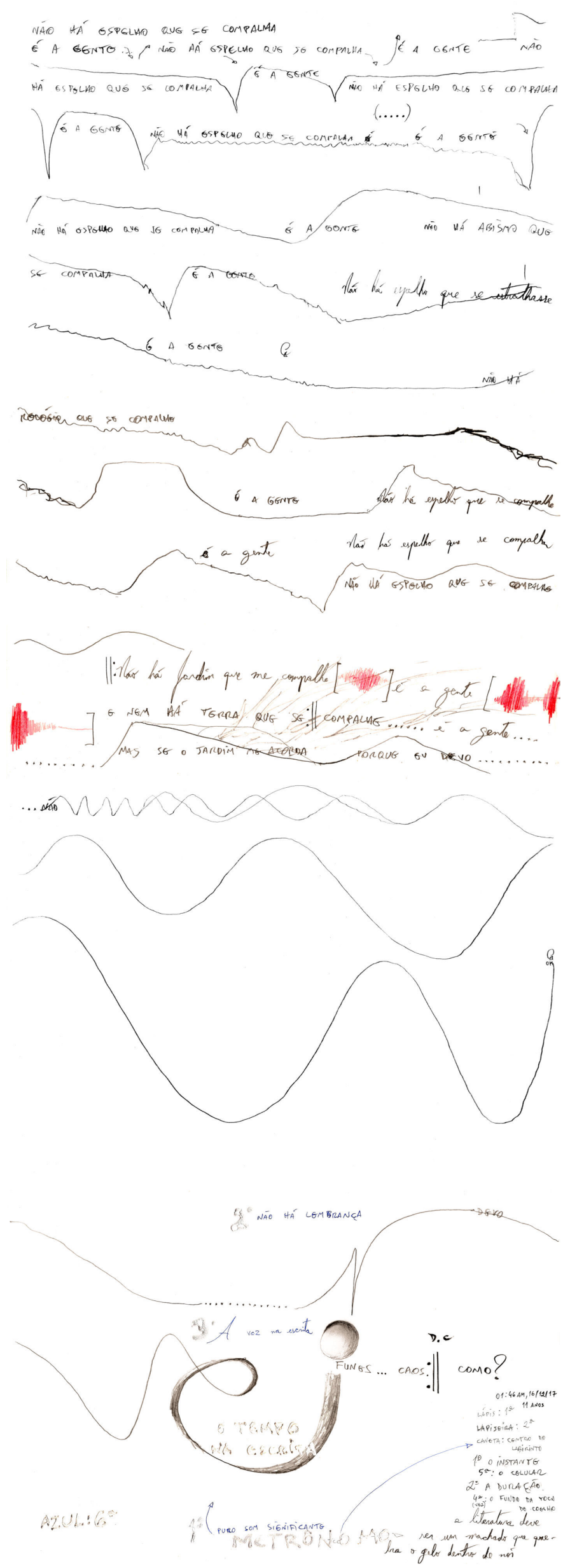

Figura 1: Primeiro experimento de desenho-escrita da respiração, dezembro de 2017. Todas as palavras foram escritas depois da linha de respiração já traçada (com exceção das duas primeiras linhas de texto). As páginas em paisagem estão aqui coladas em sequência. 
ampliação do tempo ocorresse nele, e dele irradiasse para Rafaela Lopes (harpista), cujos gestos - ora ninar seu instrumento ora bater em suas cordas - também se ampliariam.

Ou ainda a performance coletiva que foi o eixo do meu recital de conclusão de curso, cujo processo durou de março a novembro de 2018, quando então foi apresentada. Nele, um grupo de $\operatorname{artistas}^{9}$ (Alexandre D'Elboux Filho, Bruna Mayer, Isadora Borges, Lucia Esteves, Maryah Monteiro e Paola Ribeiro, além de João Monteiro no início) abraçaram a proposta de desenhar ou escrever a respiração, e juntos a derivamos nesse que foi o início do recital citado: Respire.

Foi das reflexões que vieram desses e de alguns outros processos que nasceu o projeto da pesquisa de Mestrado da qual essa dissertação faz parte. Já na pós-graduação, desenhar ou escrever a respiração tem sido, de certo modo, o operador comum a diversos outros processos, dentre eles os quatro que compõem essa dissertação.

Quando falo de operadores, refiro-me ao que move um processo ou um fluxo, o que faz com que ele ande ou corra. Poderia falar de estruturas, de planificações, mas prefiro os operadores. Não é que em cada um desses processos não tenha havido planejamentos; mas não foram de fato eles que fizeram com que as práticas continuassem vivas. São os operadores que movem a coisa - seja ela um processo de meses ou um fluxo de minutos. (FERRAZ, 2012; SIMONDON, 2015)

E insisto em não escolher por escrita nem desenho da respiração, mantenho as duas formas de relação com o ar que passa porque elas se alternam, se sobrepõem na prática do exercício. Talvez o melhor seria dizer traçar a respiração, mas com isso perderia as potências de escrever e de desenhar.

Como dizia, ao longo do processo do meu recital de conclusão de curso, Respire, compartilhei o exercício com o grupo já citado. Inicialmente, o grupo e eu focamos apenas na leitura dos exercícios que eu já tinha feito, que funcionavam como uma partitura de respiração - depois daquela primeira experiência em 2017, cheguei a refazê-la com bico de pena e nanquim, embora dessa vez tenha focado muito mais na aparência do que no fazer em fluxo. O resultado visual desse segundo exercício está na figura 2. Na leitura desses primeiros exercícios, surgiu um questionamento de Paola, de formação nas artes visuais:

Será que o traço, a linha, seria a única forma de registrar a respiração com as mãos? Se o que queremos é um registro, como então não perder a riqueza de detalhes e possibilidades da respiração? O traço dá conta disso?

E então percebemos que as regras do jogo precisavam de um pequeno ajuste. Se eu

\footnotetext{
9 Aqui, coloco nome e sobrenome dos integrantes. Ao retomá-los ao longo do capítulo, opto por usar apenas o primeiro nome, em vez do tradicional sobrenome. Assim, acontece uma dupla aproximação: entre esses integrantes e o texto, e entre o texto e a fala.
} 


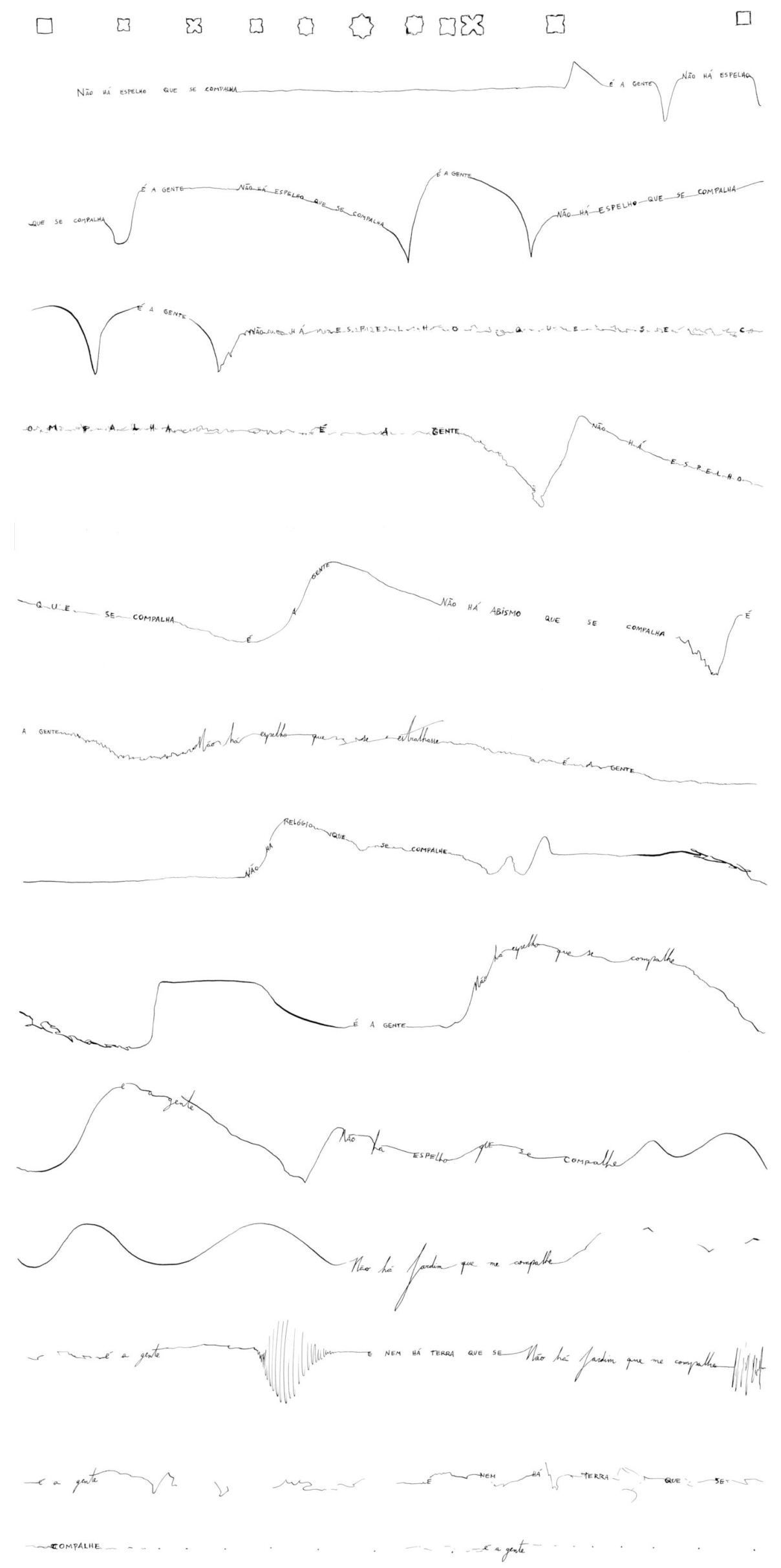

Figura 2: Segundo experimento de desenho-escrita da respiração, 2018. Nessa versão, tentei que o traço da respiração e as palavras se tornassem uma mesma coisa. As páginas em paisagem estão aqui coladas em sequência. 
posso seguir o traço, ou a mancha, quando estou em apneia, por que posso também não traçar nada, mantendo uma linha do tempo imaginária? O que diferencia um modo de apneia de outro? As regras ajustadas:

A mão só toca o papel e corre nele quando o ar também corre, seja inspirando ou expirando.

Claro, a mão tocar o papel pode ser qualquer coisa que o manche através da manipulação: um lápis de grafite, macio e confiável no traço; uma caneta bico-depena com nanquim, com suas variações mais fluidas e delicadas de peso; um pincel carregado de tinta; um carvão de desenho... E o papel também: pode ser o sulfite comum; ou o Opaline, bem liso e branco; ou o papel de arroz, levíssimo, que deixa a mancha se espalhar e é também levemente transparente; ou mesmo um grande tecido branco... Naquele momento do processo de Respire, experimentamos diversos materiais - com a ajuda de Paola - e decidimos por usar pincel de sumi-ê molhado de água, nanquim e papel de arroz. Com esses materiais, a mancha podia ser tão fina ou tão larga quanto a respiração: quanto mais o nanquim era diluído na água do pincel, mais a mancha se espalhava.

Mas, se agora a amplitude do respirar podia atravessar o papel, havia também um problema nesses materiais: como diferenciar a expiração da inspiração? Porque antes, com lápis ou bico-de-pena - usados, um no experimento inicial em 2017 e o outro já em 2018 - , com a linha, a direção do traço definia a direção do ar: se o traço sobe, o ar entra etc. Mas com a mudança de materiais, mudar o traço era menos atrativo que mudar a cor.

Ao inspirar, uma cor; ao expirar, outra. Fiz uma tira longa de papel de arroz, e nela escrevi-desenhei-pintei minha respiração num dado momento, usando nanquim vermelho para a ins- e preto para a expiração. Essa tira foi levada ao ensaio com o grupo, onde experimentamos lê-la com nossas respirações; mas como isso não é algo a que estamos acostumados, fizemos uma preparação, que consistia em sutilizar a visão e a respiração: a partir de um despertar inicial do corpo, pedi que começassem a respirar seguindo as linhas do espaço - já que a sala de Música do Espaço das Artes da ECA-USP, onde ensaiávamos, tinha algumas tubulações intencionalmente expostas, formando diversas linhas. No fim dessa preparação - que em si já fazia parte da prática -, espalhei a tira de papel de arroz, atravessando a sala na diagonal. Não indiquei nem sugeri nada além da própria colocação da tira. As pessoas passaram, então, a lê-la com suas respirações.

Mas como eu não tinha indicado o significado das cores, cada um as leu de forma diferente; notamos, depois da prática, que o que realmente indicava a ins- ou expiração era muito mais a própria forma e comprimento da mancha - o seu gesto. A mudança de cor era interessante à primeira vista mas, por ser um dado a mais na leitura, acabava dificultando a liberação da respiração. 
E, no fim das contas, o que mais nos chamou a atenção foi outra coisa. Fosse pelo fluxo preparatório conduzido antes da leitura, fosse pela necessidade de percorrer o espaço com a respiração (em vez de permanecer sentado na leitura) — ou, nitidamente, pela conjunção desses fatores - , a respiração não-cotidiana trouxe algo mais: a voz que brota, que floresce a partir do simples sopro.

\title{
2.3 A voz da respiração
}

\author{
deixar o vento entrar \\ passear pelo corpo \\ e a voz sair
}

Para falar, preciso respirar. Para vocalizar, é preciso soprar. Para que minha voz aconteça, é preciso que o ar passe pelo meu corpo. Como diz Cavarero (2011, p. 83, 86), o falar - como uma das existências possíveis da nossa voz - está profundamente radicado nos órgãos da respiração (e da alimentação, também):

\footnotetext{
a palavra alude às vísceras, ao corpo profundo onde fervem os humores das paixões. (...) Ainda que o homem seja geralmente definido como um animal falante, para atingir esse objetivo deve utilizar dois sistemas [o digestório e o respiratório] destinados a outras necessidades vitais. Deve, por assim dizer, desviá-los de sua função natural.
}

Quando falo, estou respirando; e a palavra - como "linguagem vocalizada, realizada fonicamente na emissão da voz" (ZUMTHOR, 2010, p. 11) — acontece quando acontece voz. Mas quando respiro, necessariamente minha voz acontece? Ou antes: o que posso considerar como voz?

Há muitas respostas a essas perguntas, e essas respostas acabam por definir também como encaro minha voz e minha respiração, como lido com elas. Uma resposta possível: a voz é som, "[e]la constitui um acontecimento do mundo sonoro, do mesmo modo que todo movimento corporal o é do mundo visual e táctil." (ZUMTHOR, 2010, p. 13) Um emaranhado de sons, um fluxo sonoro sempre diferente, a voz nasce a cada sopro.

Mas não é isso que entendemos por voz, geralmente. No cotidiano, apenas usamos a voz para encadear significados e ideias a interlocutores, transmitindo palavras da forma menos poluída possível; os pigarreios, o abafamento das palavras por uma máscara protetora contra Covid-19, a tosse pela fumaça, os engasgos, os bocejos as 'falhas' da voz não nos interessam no cotidiano. Nossa voz se presta à palavra, à linguagem verbal, sim, é verdade; mas as falhas são muitas, são tantas que é difícil ignorá-las.

E não as ignoramos, de fato: uma pessoa pode dizer algo, mas é a voz que comunica sua própria existência, mesmo antes que as palavras ganhem significados pela fala. 
A voz transborda a palavra, é potência sonora múltipla, ela "se diz enquanto diz". (ZUMTHOR, 2010, p. 11). E ela se diz não apenas pelos sons codificados pela linguagem verbal, mas por "soluços, suspiros, estalos de língua, gritos, gemidos, riso", como nos diz a cantora e compositora Cathy Berberian (2014, p. 47). Uma multidão de sons diferentes que brotam; a cada vez que respiro, algo acontece:

A cada sopro verificamos o nascimento ou a aparição de algo interdito. Ao mesmo tempo sabemos que essa voz é como as nossas próprias, carregadas de uma expressividade e uma proibição, a proibição transgredida do ruidoso, do ruinoso à comunicação e a uma estética do tacitamente aceito. (EL HAOULI, 1993, P. 16)

Respirar é vocalizar, seja num âmbito pequeno e suave, perceptível apenas por nós mesmos, seja numa amplitude que se derrame por todo um espaço. E se essa respiração é levada a um fluxo não cotidiano, surgem também sons não cotidianos. Não preciso de palavras para que a voz aconteça, basta respirar.

A partir do momento em que compartilhei com o grupo de artistas (referido antes) o exercício da escrita-desenho-leitura da respiração, as palavras foram aos poucos perdendo sua necessidade de existência no exercício. Aqueles pequenos versos que fizeram parte das primeiras experiências (ainda em 2017, figura 1) já não eram suficientes para a multiplicidade de caminhos que o exercício podia seguir: a respiração alterada pedia, clamava muito mais por uma voz não atrelada à linguagem verbal. E isso acontecia não apenas comigo, mas com os outros integrantes do grupo que, ao se depararem com a palavra - seja no momento de lê-la, ou de escrever uma nova - no exercício, acabavam por interromper o fluxo respiração-desenho. Mesmo na segunda versão feita em 2018, em que tentei fazer com que o traço da respiração e a caligrafia das palavras se misturassem o máximo possível, a leitura era difícil, atravancada pelas palavras (veja a figura 2).

Além do problema da não adequação da palavra ao exercício, os materiais escolhidos naquele momento do processo - pincel de sumi-ê, nanquim e papel de arroz - em 2018, pediam também um gesto mais livre, em direção à mancha que, assim como a voz, é múltipla. A escrita verbal envolveria uma precisão em maior ou menor grau do gesto, e sua leitura, uma mudança de foco da respiração para a articulação verbal; esses dois fatores, naquele momento, não faziam parte do horizonte de práticas que realizávamos. Assim, quando as palavras perderam sua necessidade, os materiais liberaram o gesto e passamos a perceber a voz inerente ao respirar, o exercício ganhou uma nova dimensão:

desenhar a respiração

deixar a voz nascer do ar que corre e vibra

desenhar a voz

ler a mancha

ler o correr do ar na mancha

deixar a voz nascer 


\subsection{Do ventre à boca, a unicidade da voz-corpo}

De um sopro que passa, nasce uma voz, e outra, e outra. O desenho-leitura da respiração, que havia nascido quase como acidente na escrita de palavras em verso, agora era um exercício de liberação da voz da respiração. Tão logo esse exercício se expandiu para os ensaios com o grupo de artistas, porém, uma característica fundamental da voz veio à tona: a diferença profunda entre as vozes do grupo, tanto em seu aspecto sonoro como afetivo. Por exemplo, uma determinada mancha, pintada a partir de uma expiração e de uma voz intensa e longa, podia ser lida por outra pessoa como uma expiração longa mas suave, ampla, com uma voz profunda. Isso tinha a ver com a ambiguidade do desenho e do próprio exercício, claro, mas havia algo além disso, uma diferença fundamental: não era a mesma voz.

Uma voz significa isso: existe uma pessoa viva, garganta, tórax, sentimentos, que pressiona no ar essa voz diferente de todas as outras vozes. Uma voz põe em jogo a úvula, a saliva, a infância, a pátina da existência vivida, as intenções da mente, o prazer de dar uma forma própria às ondas sonoras. (CALVINO, 1995)

Como o escritor Ítalo Calvino nos fala no conto Um rei à escuta, citado acima, toda voz vem de um corpo, e é tão intrinsecamente ligada a esse corpo que, assim como ele, é única. Não há como fugir dessa unicidade, porque ela chega aos ouvidos antes de qualquer outra coisa que se queira comunicar vocalmente; sabemos que essa voz que nos chega é diferente de qualquer outra, assim como ela vem de uma garganta, de um corpo diferente de qualquer outro. (CAVARERO, 2011, p. 22-23, 40)

De cada mancha, de cada vazio no papel podiam brotar sons e vozes infinitamente diferentes, não só por sua ambiguidade, mas pela diferença das vozes e corpos que os leriam. O olho lê, os pulmões, a garganta, o sopro, a voz e o corpo leem e fazem brotar no espaço sua diferença e sua unicidade, no jogo com outras vozes e corpos. Como trabalhar isso em ensaio?

Aqui, uma pequena digressão. Em agosto e setembro de 2018, dentro da programação da $33^{\text {a }}$ Bienal de São Paulo, participei de uma oficina e de uma das ativações da performance sonora Recital para um massagista ${ }^{10}$ (Récital pour un masseur), concebida por Tal Isaac Hadad, em que uma/um terapeuta corporal aplicava gestos no corpo de uma/um cantora/cantor, que vocalizava junto às vozes dos outros cantores envolvidos. Pude participar com dois terapeutas específicos: Deva Kiran (da Terapia Marma) e Lincoln Endo (da Quiropraxia e de Técnicas orientais). (BIENAL DE SÃO PAULO, 2018)

A voz e o corpo eram transformados juntos pelo toque ativo dos terapeutas. Na oficina

10 O termo "massagista" em português brasileiro não é o termo mais apropriado para traduzir "masseur": enquanto no francês tal palavra se refere a algo mais próximo a um terapeuta corporal, no Brasil há uma ligação mais direta com a prática da massagem, conforme Tal Isaac e Paola (que era organizadora e assistente da oficina e da performance) nos revelaram na ocasião da oficina; ainda assim, a organização da Bienal preferiu à época traduzir a performance literalmente. Optei aqui pela palavra "terapeuta", usada pelos profissionais envolvidos na performance. 
(ocorrida num teatro no pavilhão da Bienal), Kiran pediu, em um momento, que me deitasse em alguns cubos que estavam no meio do espaço; ali, ela aplicou um toque com pequena força à minha crista ilíaca (a região frontal-lateral do osso do quadril que pode ser sentida facilmente com as mãos), e tive a sensação de que meu quadril se abria à frente. Minha voz, que até então era um som contínuo em registro de peito, passou a ter um som "rachado", distorcido e muito intenso, sem que houvesse qualquer dificuldade nessa emissão. Senti o som ecoar pelo espaço, preenchia a sala com minha voz, que parecia nascer exatamente ali, no quadril. E logo depois, uma sensação de liberdade e leveza do corpo e da voz.

\author{
ossos se mexem \\ pequeno monstro grita \\ das entranhas
}

Ou então na ativação da performance sonora de que participei, no pavilhão da Bienal, em que, a pedido de Endo, me sentei em um cubo. O terapeuta se sentou atrás de mim e abraçou meu tórax; as costelas, coluna, abdômen, tórax, todos comprimidos. Minha voz saiu numa emissão um tanto longa e muito, muito ampla. Estava sendo comprimido, mas minha presença sonora se expandia pelo pavilhão sem que precisasse me concentrar na emissão vocal — ela simplesmente acontecia. Endo havia aliviado diversas tensões nos meus ombros e nas minhas costas, e minha voz se transformou junto.

ossos se abrem

pequenos monstros gritam

das profundezas

Voz que é corpo, corpo que é voz; presença corporal espalhada pelo espaço, som que vibra nas entranhas. Mas se essas experiências me modificaram, a pergunta permanece: como trabalhar isso em ensaio? Como, se as outras pessoas do grupo não haviam passado por tais sensações?

$$
\begin{aligned}
& \text { ouvir as vozes leves } \\
& \text { povos pássaros de sol } \\
& \text { se conversam }
\end{aligned}
$$

A multiplicidade das vozes e dos corpos, novamente, alimentou o processo. Desde o início dos trabalhos do grupo, em março de 2018, Isadora, uma das integrantes, trabalhou conosco a consciência e ativação do corpo no espaço; e Paola, outra integrante, conduziu a liberação da voz e de suas potências sonoras múltiplas ${ }^{11}$.

"I O trabalho de Isadora se fundamentou em práticas e conceitos advindos do Hatha Yoga e de práticas de educação somática, como o método Klaus Vianna e eutonia. E o de Paola, em sua pesquisa e prática como performer vocal, como artista e junto ao grupo de pesquisa Vozes Performáticas, liderado pela Profa. Dra. Wânia Storolli na Universidade Estadual Paulista (Unesp). 
Se a prática ocorrida na Bienal (com os terapeutas citados) era de certa forma intransponível para os ensaios, havia, por outro lado, um terreno fértil com o grupo para a experimentação e pesquisa da relação voz-corpo.

A partir do que eu havia experienciado na Bienal, não fazia mais sentido considerar que a partitura de respiração pudesse ser lida de forma unívoca (passando pelos mesmos estados vocais e corporais). A partitura se tornou muito mais um roteiro de fluxo, quase um pretexto para a exploração vocal-corporal. Foi nesse contexto que experimentamos juntos a leitura da tira em vermelho e preto (ins- e expiração). Ler a partitura da respiração do outro. Um desejo: fazer a partitura da própria respiração. Pintar o sopro.

Confeccionei quatro ${ }^{12}$ tiras longas de papel de arroz (totalizando mais de sessenta metros), e no final de um ensaio elaboramos juntos uma distribuição delas pelo chão de duas salas do Espaço das Artes (Átrio e Ensaio Cênicas), conduzindo o movimento dos performers através desses dois espaços ${ }^{13}$. Na figura 3 há um registro do momento posterior a essa distribuição das tiras.

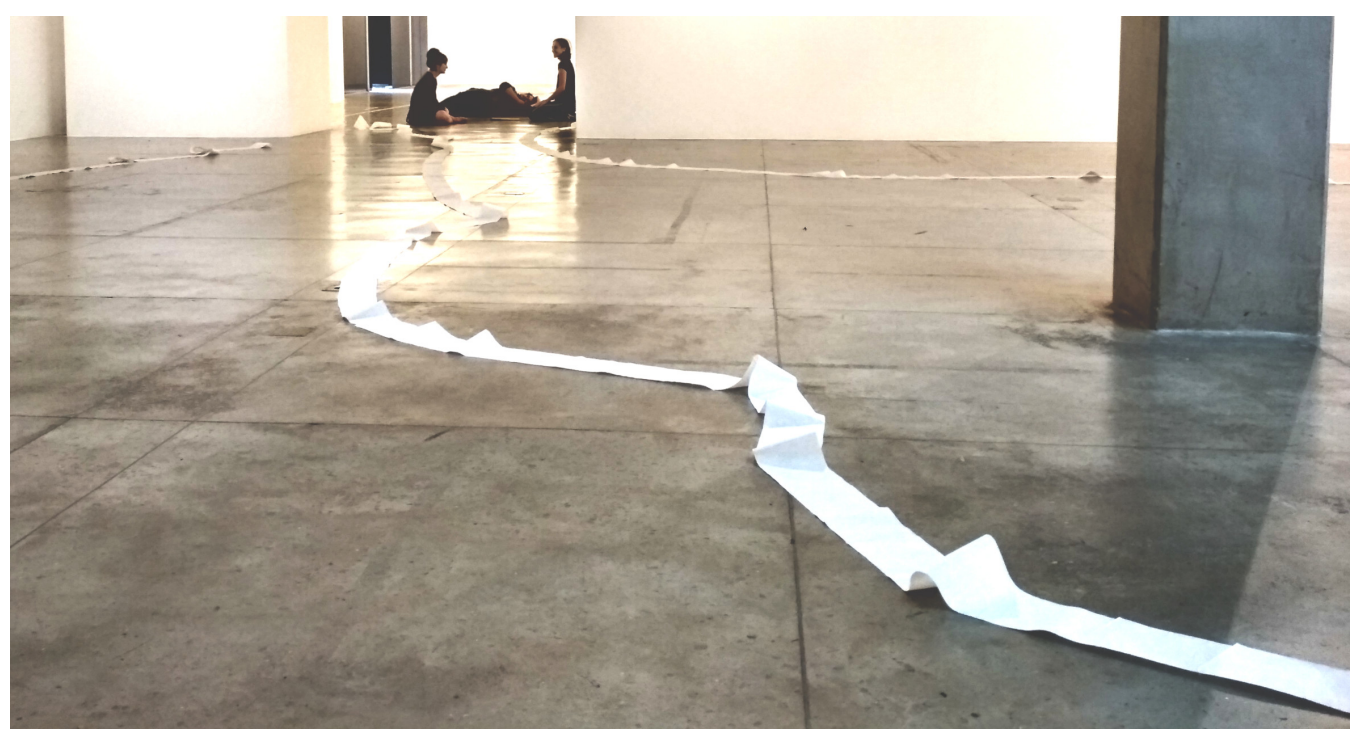

Figura 3: Quatro tiras de papel de arroz, ainda não pintadas, espalhadas pelo Átrio e pela sala Ensaio Cênicas do Espaço das Artes. Ao fundo, Maryah, Alexandre e Isadora.

E então, no ensaio seguinte, fizemos as partituras de nossas respirações. Depois de uma ativação inicial do corpo e da voz, seguindo as práticas que já realizávamos nos ensaios anteriores, distribuímos as tiras e nos posicionamos para que, pessoa por pessoa, cada integrante pintasse sua tira. Era importante para nós, naquele momento, que cada performer do grupo pudesse experimentar o exercício da forma mais simples e atenta possível: sem ter que se mover ao longo da tira, e com assistência quanto ao carregamento no pincel da tinta diluída. Quem não pintava cumpria, assim, essas

12 Por que quatro tiras apenas? Naquele momento do processo, por motivos diversos, apenas Alexandre, Maryah e Isadora podiam comparecer aos ensaios.

${ }^{13}$ Esse movimento dos performers seria tanto parte da performance como a condução entre outros momentos do recital, que ocorreriam ora em uma sala, ora em outra. 
outras funções: segurar o copo com tinta; e movimentar a tira de papel em uma velocidade mais ou menos constante. Quem pintava seguia uma regra apenas:

Quando o ar corre, o pincel encosta no papel.

Mas há um problema: carregar o pincel envolve tirá-lo do papel. E o ar, o que acontece com ele nesse momento? Não corre. A apneia ao molhar o pincel, embora pudesse ser uma segunda regra, era mais um desdobramento da conexão entre o correr do ar e o contato entre papel e tinta do pincel. Como a tira seguia sempre seu movimento, o vazio no papel era o registro dessa apneia. $E$, se antes a mudança entre ins- e expirar era registrada pela mudança de cor, dessa vez a cor era constante em cada experimento. Quem pintava podia escolher se faria com nanquim preto ou vermelho - sempre um pouco diluído em água, para permitir que a mancha se espalhasse e o pincel corresse mais facilmente pelo papel. E, de cada escrita-desenho-pintura, fizemos um pequeno registro ${ }^{14}$ :

- o experimento de Alexandre, disponível na figura 4 e em https: //youtu . be/--hDeMY JUU (acesso em 10 out. 2020);

- o experimento de Isadora, disponível na figura 5 e em https : / youtu . be/F _IziQgK60c (acesso em 10 out. 2020);

- o experimento de Maryah, disponível na figura 6 e em https : / youtu . be /f9807197LI4 (acesso em 10 out. 2020);

- o meu experimento, disponível na figura 7 e em https://youtu.be/Z2jGJ2aFb7A (acesso em 10 out. 2020);

- as quatro tiras prontas, secando no chão, disponível na figura 8 e em https : / /youtu. be/1HEa-B5FtfE (acesso em 10 out. 2020).

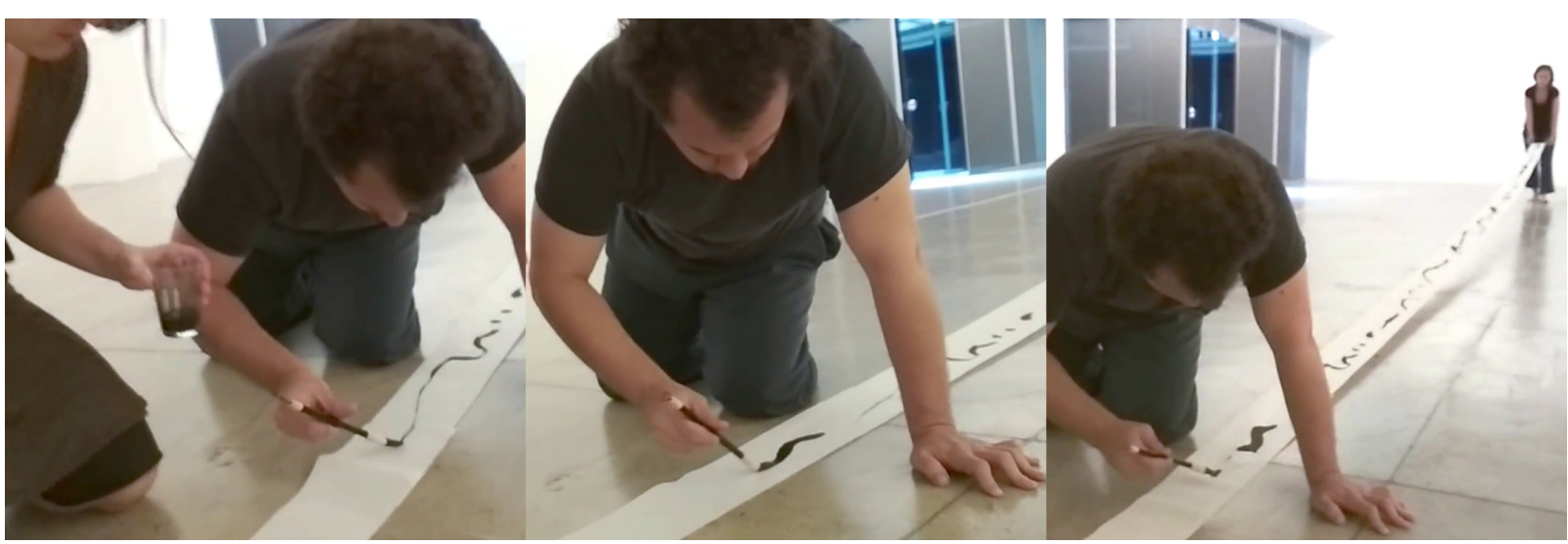

Figura 4: Escrita-desenho-pintura de Alexandre, três momentos. Segurando o copo está Maryah, e Isadora puxa a tira de papel de arroz. Vídeo disponível em https ://youtu . be/---hDeMYJUU, acesso em 10 out. 2020.

${ }^{14} \mathrm{O}$ papel de arroz é muito permeável e relativamente frágil: ao ser molhado demais, tendia a grudar no chão. Assim, movê-lo exigia a ação de duas pessoas, uma que puxava a tira e outra que cuidava para que essa não rasgasse; e como estávamos em apenas quatro pessoas, não pudemos registrar todo o processo, apenas alguns momentos. Infelizmente, também, tais registros foram feitos apenas com um telefone celular, o que implica em uma baixa qualidade de vídeo e áudio. Ainda assim, servem como memória desse momento do processo. 


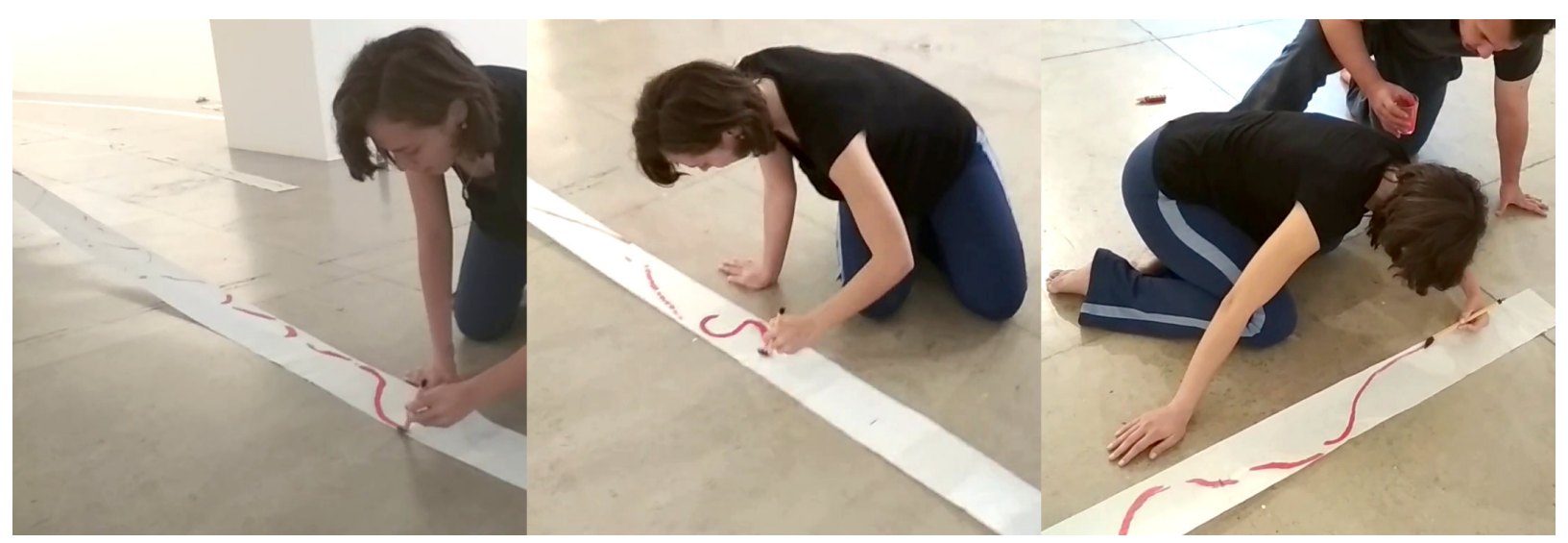

Figura 5: Escrita-desenho-pintura de Isadora, três momentos. Segurando o copo está Alexandre, e Maryah puxa a tira de papel de arroz. Vídeo disponível em https://youtu . be/F_IziQgK60c, acesso em 10 out. 2020.

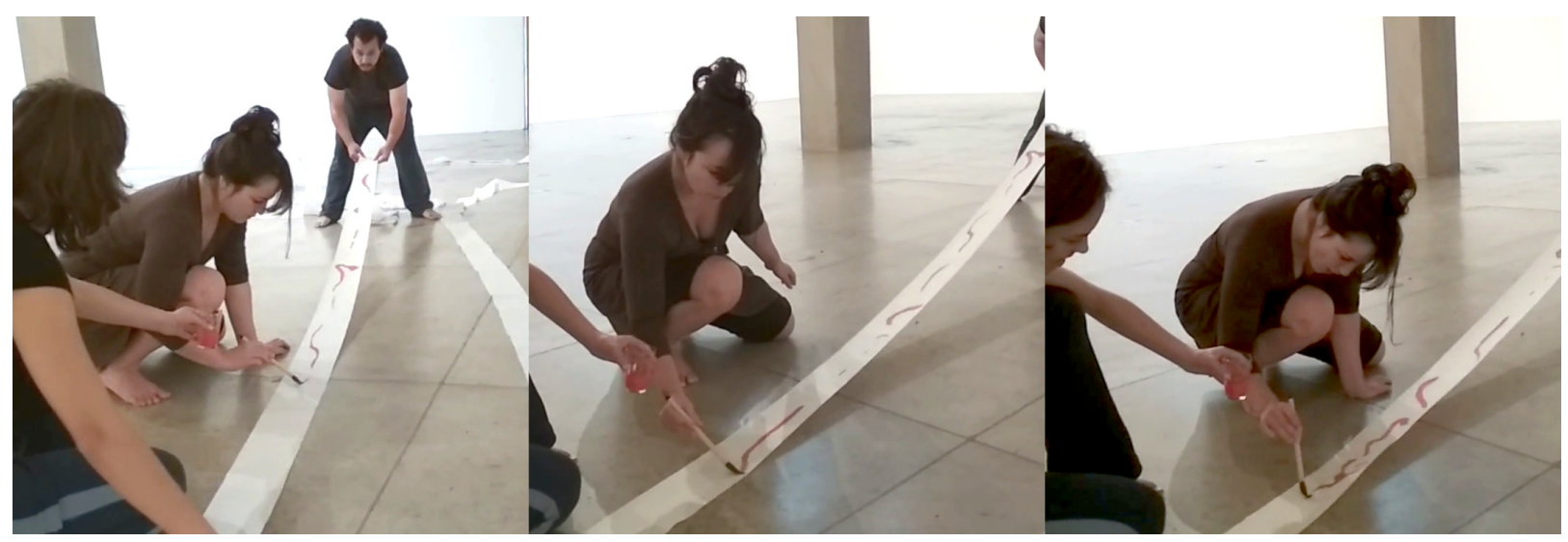

Figura 6: Escrita-desenho-pintura de Maryah, três momentos. Segurando o copo está Isadora, e Alexandre puxa a tira de papel de arroz. Vídeo disponível em https : //youtu . be/f9807197LI4, acesso em 10 out. 2020.

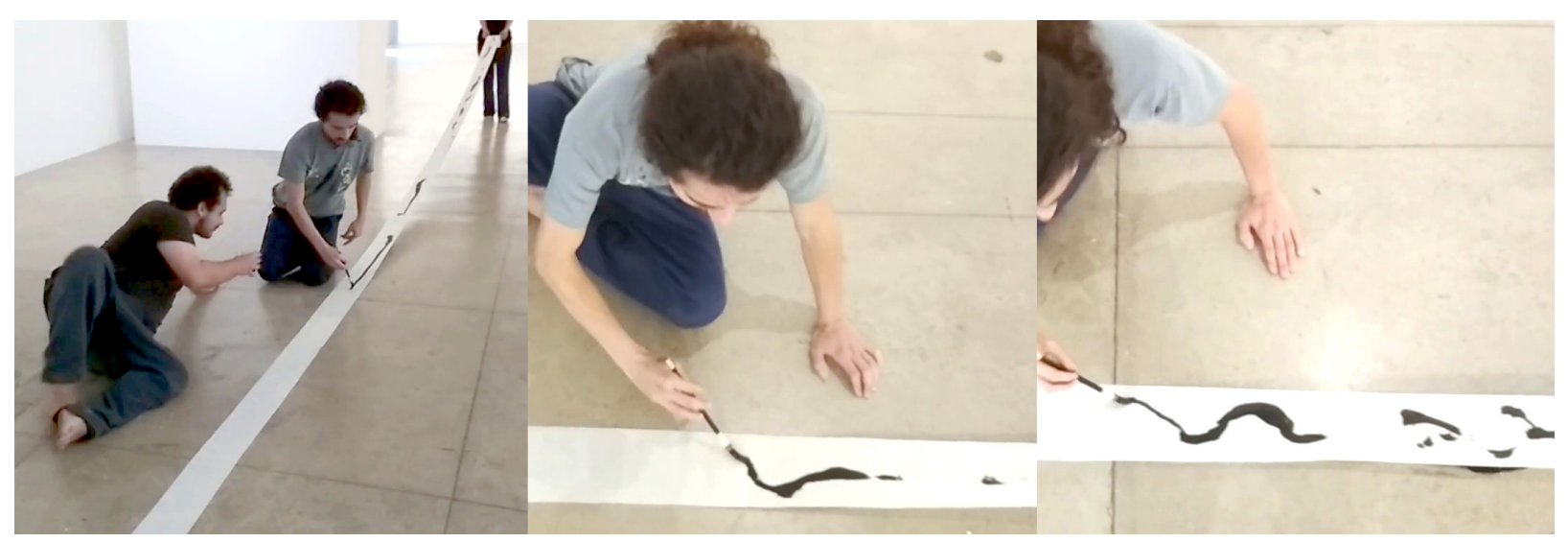

Figura 7: Minha escrita-desenho-pintura, três momentos. Segurando o copo está Alexandre, Isadora puxa a tira de papel de arroz e Maryah faz o registro. Vídeo disponível em https://youtu . be /Z2jGJ2aFb7A, acesso em 10 out. 2020.

Nesses experimentos, algo fundamental à prática também aconteceu: a relação com o espaço. Porque se uma voz é única, e essa unicidade se dá na relação com outras vozes, como Cavarero (2011) nos fala, tal relação ocorre sempre em algum espaço, e esse lugar ou ambiente modifica o corpo e a voz que estão nele. Para falar com Gernot Böhme (2014, p. 61),

[n]ós ouvimos a voz no espaço. A razão pela qual somos afetivamente influenciados por ela é que as vozes que ouvimos modificam nossa 
própria presença corporal no espaço. Encontrar-se em um espaço significa se aventurar nesse espaço por meio da percepção corporal (...). É a atmosfera que construções arquitetônicas emanam ou possuem que determina o humor [ou estado de espírito] que sentimos dentro delas através de nossa percepção corporal ${ }^{15}$.

A escrita-desenho-pintura da respiração não ocorre num ambiente isolado de quaisquer influências, por mais que se queira: é nosso corpo que respira, nossos pulmões que se enchem e se esvaziam do ar que nos rodeia, dos cheiros, da umidade (ou falta dela), é nossa pele que toca o chão, o lápis ou o pincel, e o papel não flutua, mas se apoia em algo. As vozes que brotam se espalham pelo ambiente, rebatem como som nas paredes e nos objetos, reverberam (ou não) sua presença nesse espaço. Pintar a própria respiração deitado na cama do meu quarto (primeiro experimento, a lápis, figura 1), ou sentado à mesa desse mesmo quarto (segundo, com bico de pena e nanquim, figura 2), envolvia uma presença corporal diferente de fazê-lo em pé com a tira de papel de arroz sobre a mesa desse quarto - como fiz com a primeira tira, ainda com duas cores. Mas ainda assim, o quarto levava a uma presença e atitude corporal mais contidas, tanto pela minha intimidade com o ambiente, como por seu tamanho pequeno e baixíssima reverberação: sopros pequenos, gestos pequenos, vozes pequenas.

Por outro lado, o vazio dos ambientes e das paredes, a amplitude de dimensões e a grande reverberação da sala Ensaio Cênicas e principalmente do Átrio do Espaço das Artes da USP, onde pintamos as quatro tiras, levaram a uma presença corporal e vocal completamente distinta: pequenos sopros, pequenas vozes eram amplificados e reverberados pelo espaço, cada articulação e sibilância crescia e preenchia as paredes. As vozes que brotavam da respiração percorriam os ambientes. Ao mesmo tempo, as tiras estavam no chão, o que trazia toda nossa ação corporal para baixo, limitando nossa movimentação e exigindo, na maior parte do tempo, um apoio com o braço livre. Ainda assim, o gesto do pincel podia ser bem mais amplo que em uma mesa, já que a tira se estendia reta pelo chão por vários metros.

E quando não há sopro?

\subsection{O instante e a apneia, abrir o tempo}

Desde o primeiro experimento, em 2017, a ação de escrever-desenhar a respiração não envolvia apenas registrar o ins- e o expirar, mas também os intervalos de tempo em que o ar não corre: a apneia. Ao fazer isso, ao registrar a interrupção do fluxo do ar, a atenção deixa de ignorar esse fenômeno como mero limiar entre dois movimentos

15 "We hear the voice in space. The reason why we are affectively influenced by it is that the voices we hear modify our own bodily existence in space. To find oneself in a space means to venture out into this space by means of bodily perception (...). It is the atmosphere which architectural constructs emanate or posses that determines the mood we feel ourselves in through our bodily perception." 


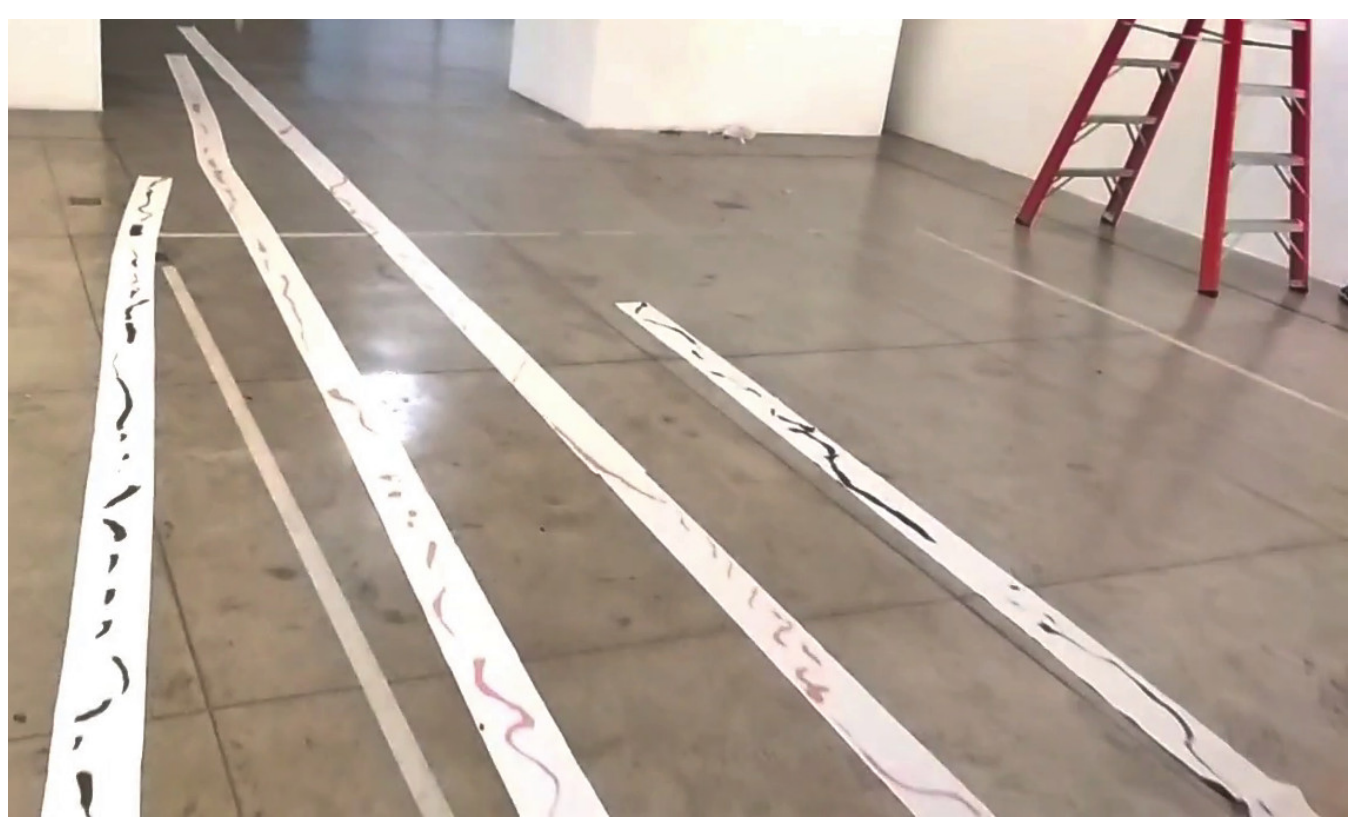

Figura 8: Quatro tiras prontas secam, depois de pintadas. Da esquerda para a direita, as tiras de Alexandre, Maryah, Isadora e minha. Vídeo disponível em https : //youtu . be/1HEa-B5FtfE, acesso em 10 out. 2020

e passa a sentir o correr do tempo. E a sensação na apneia com muito ar nos pulmões logo depois da inspiração, e que podemos, por ora, chamar de apneia cheia - não é a mesma que naquela com pouco ar nos pulmões - logo depois da expiração, ou apneia vazia ${ }^{16}$ - Sentimos o tempo passar de forma diferente em um e em outro estado.

$$
\begin{aligned}
& \text { esquecer o fôlego } \\
& \text { por um longo tempo curto } \\
& \text { ouvir o que passa } \\
& \text { esquecer o fôlego } \\
& \text { por um longo tempo curto } \\
& \text { ver o que passa }
\end{aligned}
$$

Um correr lento do tempo agonizante da apneia. O pincel, esvaziado de tinta, precisa ir ao copo, mas o ar não pode correr, não, a regra simples não o permite; levar o pincel ao copo e carregá-lo de tinta, mas não muita que o papel de arroz não aguenta, nem pouca que aí o gesto fica curto. Como?

Um curto tempo alongado: ver e ouvir o que passa, o que corre em nós e por nós. Calma, um silenciar, um esvaziamento. Esvaziar em apneia cheia? Ouvir o corpo e o silêncio da voz enquanto levo a ponta das cerdas do pincel até a superfície da tinta diluída em água, mergulho-a e a trago de volta até o papel. Cronometricamente, alguns segundos. Mas o corpo sente em cada segundo mais um passo sem sopro, mais um, e mais um, e essa sensação não pode ser cronometrada.

${ }^{16}$ Os termos apneia cheia e apneia vazia são usados aqui apenas para simplificar a escrita, não tendo relação com quaisquer termos médicos. A prática da apneia no exercício, conforme descrevo, deve sempre ser realizada com cuidado, respeitando os limites do próprio corpo. 
E quem vê, sente isso também?

Alguns meses antes, em 25 de junho de 2018, havia ocorrido a estreia da peça Beiramar, que compus em colaboração com Rafaela Lopes (harpista) e Raphael Caserta (tubista), citada no começo desse capítulo. Ao longo da peça, Caserta ia ampliando a duração tanto de sua ins- como de sua expiração, até que, no final, logo depois de uma inspiração longa e de alguns segundos de apneia cheia, ele expirava com alguns sons sibilantes e articulados e silenciava. Mas o fluxo não acabou aí: pedi que ele permanecesse por alguns segundos sem respirar, o máximo que conseguisse. Para minha surpresa, ele ficou mais de dez segundos em apneia vazia, imóvel. E aconteceu algo precioso: o público pareceu congelar durante esse tempo, sem bater palma e praticamente sem fazer som, até que ele se moveu e com ele também o público ${ }^{17}$. Esse tempo de congelamento foi percebido por várias pessoas do público (com quem falei depois da performance) como muito maior do que o tempo cronométrico.

A partir dessa experiência, ampliar a sensação do tempo se tornou um dos meus interesses no processo do exercício de escrita-desenho-pintura-leitura da respiração. Aliás, convém dizer que tal exercício havia ganhado um nome quando o compartilhei com o grupo de artistas: Respire. Ampliar como sinto o tempo, e esperar que isso gere também uma sensação de ampliação no público.

O tempo da apneia em Respire era importante e, por isso, era também registrado mesmo sendo o vazio do papel: no momento da pintura, a tira não parava de correr. E na leitura? Como não pular de uma mancha à outra com os olhos e o sopro, como resistir ao impulso de se fixar nas cores, como não evitar a apneia? Decidimos, como grupo, por liberar a leitura de uma velocidade fixa e invariável. Em vez disso, combinamos que era possível inclusive começar a leitura em uma tira e seguir por outra, mas que os vazios das tiras também eram importantes como possibilidades de leitura.

E havia outro problema ainda: ler as tiras no chão implicaria uma ação corporal direcionada sempre para baixo. A partir desse questionamento, feito por Maryah e Isadora - de formação na dança e nas artes cênicas, respectivamente -, pensamos em suspender as tiras, ou atá-las às paredes. Mas essas soluções implicavam duas coisas de que não dispúnhamos naquele momento: acesso fácil às estruturas de iluminação ou ao teto das duas salas, e tempo para experimentar com o corpo e a voz essas mudanças. Optamos então por liberar a leitura também de sua fixação às tiras: seria possível ler as linhas do espaço, suas manchas e formas, com a respiração e a apneia - prática que já havíamos experimentado algumas vezes nos ensaios.

17 Tal performance ocorreu no Espaço das Artes, dentro da programação do Painel Sonoro do Laboratório de Interpretação e Criação Contemporânea, do Departamento de Música da ECA-USP. Disponível em https : //youtu. be/s_kFKMb1MQg, acesso em 11 out. 2020. 


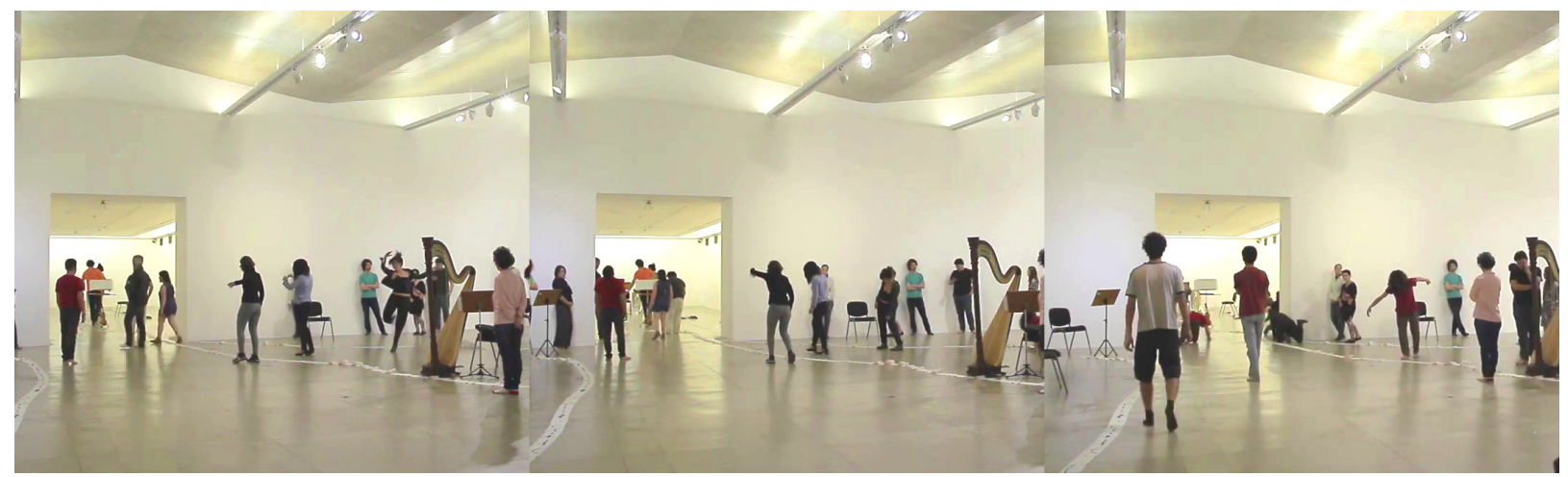

Figura 9: Três momentos de Respire no Recital de Conclusão de Curso, ocorrido em 27 de novembro de 2018, no Espaço das Artes da USP. Vídeo disponível em https : //youtu . be/qyHsw6KpdZk, acesso em 12 out. 2020. Edição: Lucia Esteves.

Assim, fizemos a etapa de leitura performática de Respire no dia 27 de novembro de 2018, como performance que envolveu principalmente as quatro pessoas que pintaram as tiras (Alexandre, Isadora, Maryah e eu), além de Lucia Esteves, que fazia parte do grupo. Na ocasião, como já dito antes, a performance era o início e fio condutor do meu Recital de Conclusão de Curso, junto a outras peças e performances. O vídeo do recital está disponível em https : / / youtu . be/qyHsw6KpdZk (acesso em 12 out. 2020) e na figura 9. Apesar dos contratempos do dia, foi maravilhoso contar com a participação generosa dos outros músicos do recital também em Respire, porque todos toparam fazer o exercício de leitura da respiração, mesmo que fosse pela primeira vez: Lucas Raulino, Rafaela Lopes e Raphael Caserta.

O recital, que começou com Respire, passou por duas outras peças, uma performance e se encerrou com Beira-mar, foi um fluxo contínuo que, de certa forma, culminou com o congelamento da respiração de Caserta - dessa vez, aumentado para mais de dezesseis segundos - , um silêncio do espaço que se seguiu mesmo quando Raphael se mexeu. Tempo, ampliado pela respiração, congelado.

Sugiro agora que a leitura salte ao capítulo 3, continue pelo capítulo 4 e depois retorne à seção abaixo - no final daquele capítulo há uma referência para voltar para cá.

\subsection{Traçar no sopro do palco}

Ler a respiração plasmada nas tiras de papel de arroz, ler seus ritmos, curvas, intensidades e vazios com o sopro e o corpo, e deixar que a voz brote e se espalhe pelo espaço, envolva a todas e todos que estão em volta, ampliar a respiração, a presença atmosférica até com ela tocar o outro.

Nesse processo de 2018 de Respire, havia um elemento que era anterior ao momento da performance e que, assim, era uma espécie de segredo: o momento da escrita-desenhopintura da respiração. $\mathrm{Na}$ época, eu considerava que tal etapa era sensível demais às influências externas, e que, por isso, deveria ser realizada dentro de um ambiente de conforto, por assim dizer, de um ambiente ao mesmo tempo amplo e isolado. As quatro tiras (cujos vídeos de registro estão nas figuras 4-7) daquele ano foram 
pintadas segundo essa concepção: num dia e horário em que não havia ninguém no Espaço das Artes exceto funcionários da portaria e administração, e quando os ruídos externos ao prédio não ofereciam distração. Mesmo as nossas próprias preocupações eram pequenas naquele dia: dispúnhamos de tempo suficiente para a experimentação.

Mas a leitura performática dessas tiras (conforme registro na figura 9), por outro lado, aconteceu num ambiente quase oposto: muitas pessoas em volta, muitos sons externos à respiração, e diversas preocupações que dificultaram tanto uma preparação mais calma e aprofundada como a própria sutilização e sensibilização da respiração e da voz durante a leitura. Ficamos, como grupo, com o desejo de aproximar as duas etapas - pintura e leitura - , fosse por uma quietude da leitura (num registro em vídeo, por exemplo) ou pela exposição, pela feitura performática da pintura.

O que queremos dizer com performático? Abarcamos, aqui, tanto a concepção mais propriamente musical, segundo a qual performance é o momento em que a música acontece, na relação entre pessoas - sendo a música, assim, uma arte da performance, como nos diz Nicholas Cook (2006, p. 7) —, como também a multiplicidade de sentidos que o termo adquiriu ao longo do século XX em diversas manifestações artísticas, havendo, nessa encruzilhada de acepções, uma espécie de centro: o corpo colocado em evidência, em sua temporalidade e concretude (HOLDERBAUM, 2014, p. 42-44). Realizar uma pintura performática, uma leitura performática, assim, seria fazê-las na relação com outras pessoas, relação essa intimamente corporal: pela presença, pelo aqui-agora dos corpos, vozes e respirações que compartilham o mesmo espaço. Em vez do segredo da pintura feita antes da performance, a respiração e a voz surgindo junto com a mancha junto ao público.

Já no Mestrado, em 2019, pude participar como aluno especial da disciplina Pesquisa vocal nos processos criativos contemporâneos, ministrada por Wânia Storolli no Instituto de Artes da Universidade Estadual Paulista (IA-Unesp) ${ }^{18}$. Ali, discutimos e nos aprofundamos no pensamento de Adriana Cavarero, em seu livro já citado Vozes plurais (2011), além de outros autores; e travamos contato com o pensamento de Antonin Artaud - tanto em seu O teatro e seu duplo (2006) como em suas cartas, escritas num hospital psiquiátrico de Rodez (1981).

E então, no planejamento do sarau de conclusão daquela disciplina, pude retomar Respire, quase seis meses depois da apresentação do Recital de Conclusão de Curso. Inicialmente quis incluir na performance apenas a leitura; depois, por sugestão de Storolli e dos outros alunos da disciplina, além da influência de outro processo de que falo logo adiante, decidi inserir na performance também a escrita-desenho-pintura, mas não sabia ao certo como fazer isso. Incluir o grupo de artistas de 2018 não era possível, por dificuldades de agenda; assim, ou faria a performance sozinho, ou com

${ }^{18}$ Essa disciplina de pós-graduação fazia parte do Programa de Pós-Graduação em Artes, sendo ligada ao Departamento de Artes Cênicas, Educação e Fundamentos da Comunicação do IA-Unesp. 
os artistas que participavam da disciplina. E, de qualquer forma, havia pouco tempo: faltavam algumas semanas para a data do sarau, e não era possível encontrar horários disponíveis para ensaios com as pessoas interessadas.

Havia também outro problema: a pintura com pincel de sumi-êe papel de arroz era um processo delicado, que exigia uma certa familiaridade, prática e tempo de experimentação; e exigia também uma certa adequação do espaço da performance, para que o papel não rasgasse nem grudasse no chão. Mas não havia nem tempo, nem acesso ao espaço em que ocorreria o sarau (o Teatro Reynuncio Lima do IAUnesp). Assim, por sugestão de Paola, do grupo de 2018 e também aluna da disciplina, experimentei uma mudança: em vez de pincel e tinta, carvão grosso de desenho; e em vez de papel de arroz, um tecido branco 100\% algodão.

$\mathrm{Na}$ época, estava envolvido em um processo com Giovanna Airoldi (detalhado no capítulo 4), em que experimentávamos diferentes materiais para uma performance que envolvia, também, a pintura. Nesse processo, antes mesmo que surgisse a ideia de remontar Respire, havia a ação de pintar em performance (cf. seção 4.3); de modo que as práticas desse processo colaboraram muito para que decidisse incluir, na Unesp, a escrita-desenho-pintura da respiração. Além disso, dois pedaços grandes de tecido branco de algodão acabaram sobrando naquele processo, por não se adequarem à tinta que usávamos. Esses dois pedaços seriam o material de base para a remontagem de Respire: $\operatorname{costurados}^{19}$, formavam um retângulo de aproximadamente 1,5 metro por 1,8 metro. Esse tamanho exigia que eu ficasse em cima do tecido em algum momento; mas, como o tecido era grosso e resistente, não havia perigo de rasgá-lo. Assim, não era preciso que alguém movesse o tecido, como havia ocorrido com o papel de arroz em 2018.

E o carvão grosso, sugerido por Paola, tinha a vantagem de não exigir nem o copo nem o carregamento de tinta. Assim, a ação de escrever-desenhar-pintar a respiração era simplificada, porque a sua regra única não derivava em uma apneia limitada pela ação de mergulhar o pincel no copo com tinta.

Por outro lado, a escrita-desenho-pintura voltava a se basear mais em traços do que em manchas: embora o carvão fosse um material bastante macio, permitindo uma grande variação na espessura do traço - podia inclusive usá-lo de lado, com o bastão perpendicular ao traço - isso não chegava a configurar uma mancha como a da tinta no papel de arroz. Mas, se não era mais tão possível chamar a prática de escritadesenho-pintura, a influência, a liberdade da mancha permaneceu. Mudanças nos materiais, mudanças na prática, mudanças na performance.

Mas a leitura, por outro lado, não pôde ser trabalhada: para fazê-lo, seria necessário escrever-desenhar uma versão prévia e levá-la a algum encontro com os artistas

19 A costura dos dois pedaços de tecido, bem como o arremate e acabamento de suas bordas, foi feita pela costureira Solange, que trabalha no Conjunto Residencial da USP. 
interessados. Infelizmente, não houve nem tempo nem materiais disponíveis para tanto.

No dia 27 de junho de 2019, aconteceu o Sarau Vozes Inauditas, de encerramento da disciplina citada, em que diversos trabalhos foram apresentados, individuais e em grupo. Como temas centrais, a pluralidade da voz, as cartas de Artaud, a performance. Ali, pude remontar Respire em duas partes ${ }^{20}$ :

1. A escrita-desenho da respiração: feita por mim como segundo trabalho na programação do sarau. Fotos disponíveis na figura 10, áudio em https : / /soundcloud.com/josedemattosneto/respire-criacao-da-partitura (acesso em 14 out. 2020);

2. A leitura da respiração: feita por Wânia Storolli, Luciana Marcon e Adriana Mello, como penúltimo trabalho do sarau. Áudio disponível em https : / / soundcloud .com/josedemattosneto/respire-leitura-da-partitura (acesso em 14 out. 2020).

Se não houve tempo para trabalhar a prática com os novos materiais, nem para trabalhar a leitura com as três artistas (Storolli, Marcon e Mello), como se deu a performance? Como ela foi preparada?

Para que alguma coisa relevante ocorra, é preciso criar um espaço vazio. $O$ espaço vazio permite que surja um fenômeno novo. (BROoK, 2000, p. 4)

Para alcançar tal esvaziamento, optei por reservar bastante tempo de preparação pessoal antes do início do sarau. Nessa preparação, uma ação simples: passar com ferro quente, no chão do palco do teatro, o tecido e a roupa da performance. Essa ação levou em torno de quarenta minutos, e com ela pude deixar as preocupações e a ansiedade um pouco de lado e me concentrar em algo simples: deixar o tecido e a roupa o mais plano possível.

Além dessa preparação pessoal, tive alguns minutos com as três artistas citadas. Dei um pedaço de carvão a elas e um tecido menor e pedi que experimentassem a escritadesenho da respiração. Como o tempo era curto e a preocupação de todos era ampla com a iminência do sarau, tal experimento durou pouco; então expliquei a regra a elas: Seguir o traço e a mancha com a respiração; quando há traço, o ar corre. No vazio, apneia.

Não determinei nada além dessa regra. Como a escrita-desenho ocorreria no começo do sarau, e a leitura só no final, combinamos que eu levaria o tecido para um canto do palco no final da minha parte (escrita-desenho), e antes da leitura levaríamos

${ }^{20} \mathrm{O}$ registro das duas partes foi feito apenas em áudio e fotos. Tive acesso às fotos apenas da primeira parte. 


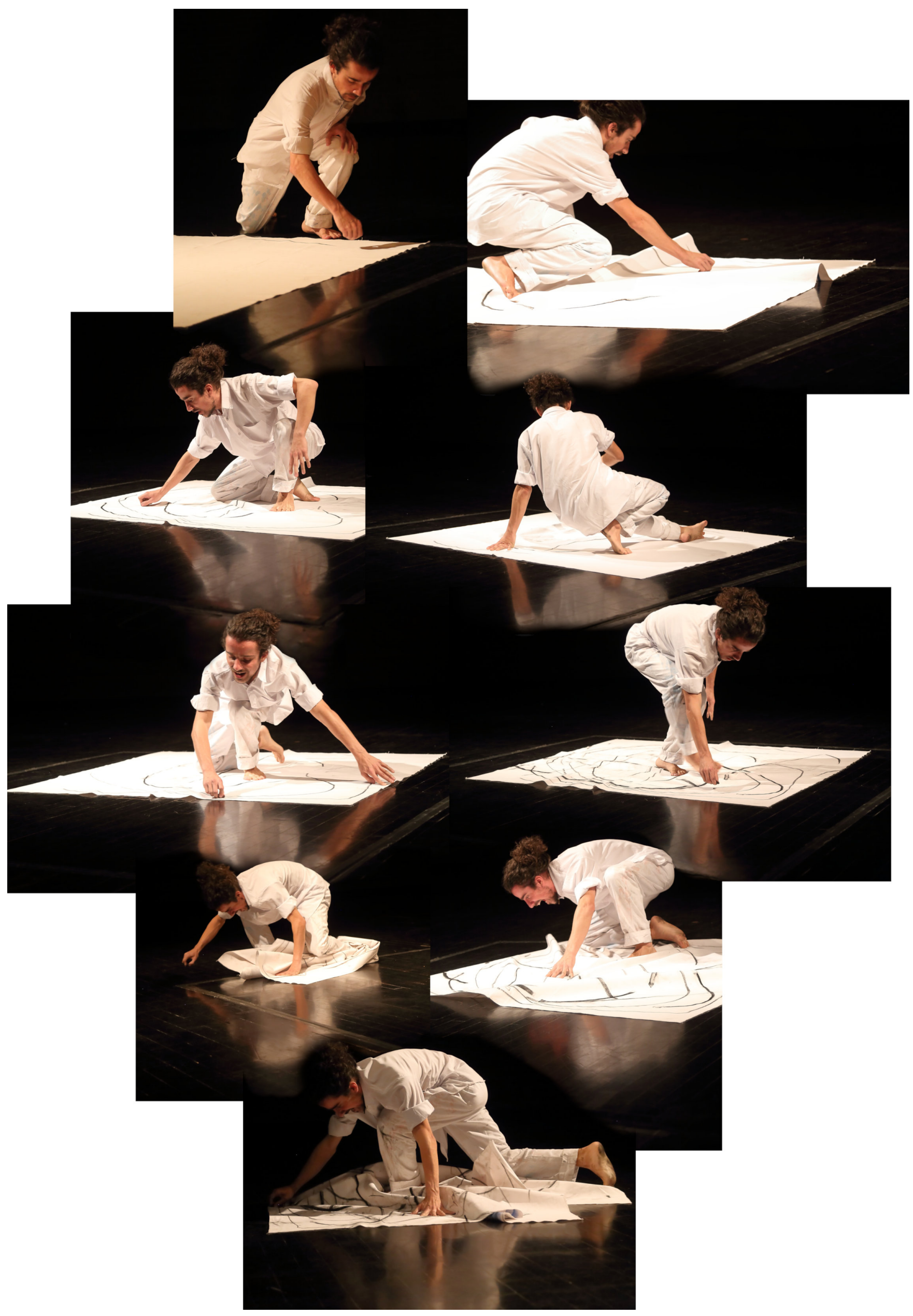

Figura 10: Primeira parte de Respire no sarau Vozes Inauditas, no Instituto de Artes da Unesp. Áudio disponível em https://soundcloud.com/josedemattosneto/respire-criacao-da-partitura (acesso em 14 out. 2020). Fotos por Antônio Gama. 
os quatro o tecido de volta ao centro do palco, quando então eu as deixaria e elas começariam a leitura ${ }^{21}$.

Mas é preciso dizer que houve uma preparação pela qual não fui responsável: antes do início do sarau, Wânia Storolli fez, com todos os integrantes, uma prática de respiração vivenciada - que pode também ser encontrada em sua tese (STOROLLI, 2009) -, que abriu aquele espaço vazio fundamental, do qual Brook (2000) nos fala.

Não apenas Brook, na verdade: Quilici (2012, p. 100, grifo nosso), ao falar de como Artaud desejava que o teatro fosse poesia no espaço, nos diz que, para ele, "o teatro deve operar no espaço mantendo sempre a relação com esse vazio prenhe de possibilidades, prestes a se desdobrar, nos remetendo sempre a esse trânsito entre ser e não-ser".

Artaud (2006, p. 103) desejava e propunha que as palavras não fossem mero veículo de significados, mas que, mais que isso, fossem encantatórias; que a voz tivesse uma materialidade concreta no espaço. Para ele, a "linguagem objetiva e concreta do teatro (...) impele a voz. Utiliza vibrações e qualidades de voz. Faz ritmos baterem loucamente. Martela sons." E, em busca dessa voz material, quase táctil, ele se deparou e trabalhou com a respiração:
Assim, tive a ideia de empregar o conhecimento da respiração não apenas no trabalho do ator, mas também na preparação ao ofício de ator. - Pois, se o conhecimento da respiração ilumina a cor da alma, com maior razão pode provocar a alma, facilitar seu desenvolvimento. Não há dúvida de que, se a respiração acompanha o esforço, a produção mecânica da respiração provocará o nascimento, no organismo que trabalha, de uma qualidade correspondente de esforço. (...) O que a respiração voluntária provoca é uma reaparição espontânea da vida.
“(...) Conhecer as localizações do corpo é, portanto, refazer a cadeia mágica.
"E com o hieróglifo de uma respiração quero reencontrar uma ideia do teatro sagrado. (ARTAUD, 2006, p. 155, 173)

Remontar Respire em 2019 foi uma retomada desafiadora de um processo que, até então, havia ocorrido entre artistas próximos, com quem tinha intimidade suficiente para experimentar práticas e propostas com grande liberdade. Ainda assim, o encontro com os alunos da disciplina de Wânia Storolli foi riquíssimo: todos estávamos experimentando, ali, propostas que eram saltos no abismo, no desconhecido. Havia uma generosidade e uma liberdade muito grandes, assim, em não só acolher as propostas dos outros como também propor novos caminhos e

${ }^{21}$ Depois da leitura feita por Storolli, Marcon e Mello, todos os integrantes do sarau percorremos o espaço atrás do público, contornamos o palco e nos dispusemos do seu lado direito, direcionados para uma projeção no fundo do palco. Fizemos um pequeno movimento para frente e para trás, com sons da respiração, por alguns minutos, e então congelamos o movimento. Durante tal congelamento, o público não bateu palmas nem fez sons por alguns minutos. Esse encerramento foi proposto e conduzido por Storolli. 
olhares - como as mudanças feitas na minha performance, sugeridas e auxiliadas por Paola, Storolli e outras pessoas - e mesmo participar das propostas - como Storolli, Luciana Marcon e Adriana Mello, que participaram da minha performance, assim como participei da performance Carta de Reis, com Paola e Rômulo Alexis, naquele sarau. Foi maravilhoso assistir a Storolli, Marcon e Mello, artistas com quem tinha pouca intimidade e que desconheciam o processo de 2018 , lendo o desenho de respiração com suas vozes pelo espaço, criando imagens (sonoras, visuais) múltiplas; foi maravilhoso ver como um processo criativo, quando revisitado e aberto a novos encontros, pode multiplicar suas potências nas vozes que surgem.

Além disso, recriar Respire incluindo dessa vez a escrita-desenho na performance, em um sarau cujo centro temático era o pensamento de Artaud, foi experienciar minha voz como corpo no espaço, a respiração que abre a pele, os fluidos, os ossos para a escuta, que faz correr som, voz, por cada poro. Uma experiência que seria aprofundada algum tempo depois.

\title{
2.7 Das vozes que brotam no vazio
}

\author{
a brisa passa \\ por folhas galhos e tronco \\ leva a poeira
}

Volto a 2018: em 25 e 26 de outubro daquele ano, participei da oficina De Roy Hart à redescoberta de Alfred Wolfsohn: vozes que criam, ministrada pela Profa. Dra. Paula Molinari, professora da Universidade Federal do Maranhão (UFMA) e também Roy Hart Voice Teacher ${ }^{22}$. Ali, tive contato com uma abordagem em que a voz era trabalhada, estudada fora das classificações vocais (soprano, contralto, tenor, baixo etc.), estreitamente ligada ao corpo, a seus movimentos e afetos.

Cheguei a tentar trazer algumas das práticas da oficina para os ensaios de Respire do meu recital de conclusão; mas havia algo de irrepetível nelas, algo além de uma sequência de indicações: uma escuta aberta à multiplicidade da voz. No final do segundo dia de oficina, conversei com a professora sobre a possibilidade de aprofundar aquele trabalho, ao que ela me sugeriu um período mais longo de estudos intensivos, uma residência artística.

Ao longo de 2019, Paula Molinari, Paulo Rios (à época também Prof. Dr. da UFMA), parte do grupo de artistas de 2018 - Alexandre, Bruna, Isadora e Paola - e eu

22 Essa oficina ocorreu dentro da programação do VI Seminário Vozes Performáticas: voz, corpo e gênero, no IA-Unesp, coordenado pela Profa. Dra. Wânia Storolli. Prefiro a denominação "Roy Hart Voice Teacher", por ser usada por Paula Molinari tanto presencialmente como em sua tese de doutorado. (MOLINARI, 2013, p. 65) 
organizamos ${ }^{23}$ tal residência artística. Ela aconteceria em um centro cultural em Parnaíba, Piauí, cidade vizinha a São Bernardo (já no Maranhão), local do campus em que os professores trabalhavam. O período: de 14 a 24 de agosto de 2019.

Por que falo dessa residência artística aqui? Bem, a princípio ela pode parecer "apenas" um estudo vocal-corporal aprofundado, sem relação direta com a criação e a composição - e era o que pensávamos também como grupo. Mas não foi bem assim, por dois motivos: primeiramente, tanto Paula como Paulo ${ }^{24}$ são compositores e, sendo assim, as questões da criação musical perpassam suas atividades e elaboração conceitual; em segundo lugar, a própria abordagem vocal de Paula é ligada diretamente à criação artística.

Tal abordagem é baseada principalmente no Roy Hart Theatre Voice Work, do qual, como já disse, Paula é professora certificada. Mas que trabalho é esse? Um pequeno resumo: ele vem das práticas e ideias desenvolvidas por um grupo chamado Roy Hart Theatre, surgido e desenvolvido a partir de 1962 ao redor de Roy Hart que, por sua vez, era aluno desde 1947 de Alfred Wolfsohn, professor de voz que desenvolvera, desde a década de 1930, um trabalho de ensino baseado na escuta e liberação dos bloqueios da voz. Como Paula diz em sua tese,

\footnotetext{
Roy Hart não foi um purista na aplicação e tampouco se pode dizer que tenha sido um curador do pensamento de Alfred Wolfsohn. O que ele fez foi traduzi-lo para a linguagem teatral (...). Na oralidade e no fascínio do trabalho de Roy Hart, misturaram-se elementos de Alfred Wolfsohn e do próprio Hart, e é o que nos transmitem aqueles que vivem até nossos dias. (MOLINARI, 2013, p. 3, 7)
}

Embora o grupo tenha passado por grandes transformações (com a morte prematura de Roy Hart em 1975, ou mesmo as inquietações com a idade avançada dos membros a partir de 2002), seu local principal de trabalho e convivência se manteve o mesmo, o Centre Artistique International Roy Hart, no sul da França. (MOLINARI, 2013, p. 7-8, 65) Foi lá que Paula fez sua formação, tanto na abordagem em si como em professora dessa abordagem. Além dessa formação, Paula estudou também a prática e os princípios pedagógicos do próprio Wolfsohn, buscando encontrar e desenvolver as potências musicais desse trabalho ${ }^{25}$.

Dentre as muitas conversas da residência artística com Paula, em uma específica, no dia 22 de agosto, ela nos explicou que, para ela, esse trabalho de voz está voltado

${ }^{23}$ Nessa e na próxima seção, uso várias vezes a primeira pessoa do plural, "nós"; nesses momentos, falo do grupo que foi à residência. Lucia e Maryah, também integrantes desse grupo de 2018, foram convidadas a irem à residência, mas por dificuldades diversas não puderam participar.

${ }^{24}$ Apesar da semelhança dos primeiros nomes, novamente prefiro usá-los em vez dos sobrenomes dos professores, já que construímos uma relação próxima ao longo da residência artística, o que me faz tomar tal liberdade.

${ }^{25}$ Tal estudo de Paula se deu a partir de duas fontes principais: o manuscrito Orpheus: oder der wegzueimer maske (Orfeu: ou o caminho para a máscara) do próprio Wolfsohn, e a série de quadros Leben? oder Theater? ein Singspiel (Vida? ou Teatro? uma peça musical) de Charlotte Salomon, aluna dele. (MOLINARI, 2013) 
para a criação. A inquietação principal de Wolfsohn era descobrir de onde vem, no ser humano, a capacidade de fazer arte, de criar arte; e é pela voz, através dela, com ela que ele alcança esse lugar interno da criação. E o que é esse lugar?

Um lugar genuíno? Um lugar que seja real para mim naquele momento? Em que, naquele momento, simplesmente existo? Ou, como Isadora disse naquela conversa (a partir de seus estudos da obra e práticas de Constantin Stanislavski e seus discípulos), um lugar de vida? De experiência? E mais: atingi-lo com a voz?

$$
\begin{aligned}
& \text { nem luz nem sobra } \\
& \text { como seguir o meio } \\
& \text { sem dizer seu som? }
\end{aligned}
$$

Wolfsohn chega a dizer, em um livro datilografado em que compila suas ideias sobre sua prática ${ }^{26}$, que cantar é uma prática que não pode separada da questão humana; não apenas um prazer estético, mas a expressão mesma do ser humano. (MOLINARI, 2013, p. 43) É nesse sentido que ele atinge aquele lugar de que falei com o trabalho vocal que desenvolve:

\footnotetext{
Alfred Wolfsohn fala nisso num depoimento em que associa o mergulho na voz a um mergulho em território profundo, o lugar que ele buscava, um lugar que parece ser a efervescência da criação. É como um grande vulcão cuja erupção precisasse de um motivo: suas profundezas se movem, e a voz sai com tanta informação que jorra criando novas formas, novo território, nova geografia de ser. (MOLINARI, 2013, p. 31, grifo meu)
}

Aqui, um problema: esse lugar da criação - ou mesmo o caminho até ele — seria fixo, imutável? Outro problema: se, para Wolfsohn, a voz pode expressar o centro energético do ser humano, como falar de geografia de ser? A expressão, como abordada por Wolfsohn, parece ser aquela associada a um ser coerentemente integrado, unificado; mas em uma geografia de ser acontece o contrário: caminhos diversos que se cruzam, lugares distribuídos sem uma coerência predeterminada, linhas sem começo nem fim, encruzilhada de encruzilhadas - "há toda uma geografia nas pessoas, com linhas duras, linhas flexíveis, linhas de fuga etc." (DELEUZE; PARNET, 1998, p. 18, 36) Como falar de um centro único em uma geografia de ser?

$$
\begin{aligned}
& \text { quando o passado } \\
& \text { e o futuro se calam } \\
& \text { o vento sopra }
\end{aligned}
$$

Como disse antes ao falar da oficina em 2018, o trabalho vocal de Paula se baseia na quebra dos bloqueios da voz, "libertando-a para seus extremos, graves e agudos, sem preocupação com os limites da tessitura", sem a preocupação de enquadrar a voz em uma classificação vocal, de encaixá-la (ou encaixotá-la) em uma concepção prévia

\footnotetext{
${ }^{26}$ Tal livro é o manuscrito citado na nota anterior.
} 
do que seja uma voz feminina ou masculina, grave ou aguda. (MOLINARI, 2013, p. 3) Quebra-se aí uma primeira categorização da voz, uma primeira tentativa de fixá-la em características definidas a priori quanto à sua tessitura e suas regiões de brilho.

Mas não há uma voz apenas. Como disse antes, na seção 2.3, a cada sopro, a cada respiração nossa voz renasce, sempre diferente. De modo que não basta ampliar a tessitura da voz, ainda que seja a seus extremos, para libertá-la; é preciso trabalhá-la como múltipla:

\section{Aparecerão muitas vozes da mesma voz. A busca volta-se então para um repertório de vozes possíveis, e cada uma delas descortina um timbre que se conquista ao mesmo tempo em que se conquista uma imersão em si. (...) Somos um universo a visitar. Nesse universo, existe uma voz para cada molécula, composta, no mínimo, de dois átomos. (MOLINARI, 2013, p. 62, 64)}

Ao longo da residência artística, tanto eu como os outros integrantes do grupo Alexandre, Bruna, Isadora e Paola - passamos por diversas liberações da voz, cada um de uma vez. Descobrir uma voz minha que nunca tinha ouvido, e que sequer imaginava que fosse possível - isso se tornou recorrente ao longo dos dias de prática com Paula. E essa experiência não é, como talvez possa parecer, particularmente confortável.

Em um dos dias, pude passar por isso de forma mais intensa. Na ocasião, Paula trabalhou comigo a extensão vocal para a região do extremo agudo, através de vocalizes (cada um permanecendo sobre uma única nota) conduzidos por ela enquanto Alexandre, com a mão apoiada sobre meu esterno (osso do meio do peito), fazia com que meu corpo oscilasse para frente e para trás rapidamente. Essa ação dele, sempre orientada e observada por Paula, foi se intensificando quanto mais aguda era a região que eu cantava.

Em um determinado ponto dessa prática, senti um bloqueio interno: uma sensação muito nítida de estar à beira do desconhecido, do que não era eu; e ao mesmo tempo, um apego muito grande, uma vontade de permanecer em vez de dar o passo à frente. As palavras mesmas fugiram, e esse apego era também uma tentativa de trazê-las. À beira do abismo, uma perda de lucidez, um desconhecido que era morte. Paula me perguntou se eu queria continuar, ou se preferia ficar por ali, e me deu total liberdade de escolha - já que, como ela sempre frisou, a escolha é sempre do aluno. (MOLINARI, 2013, p. 61) Mesmo com aquela sensação - e os olhos prestes a chorar - decidi seguir.
esquecer o pensar
deixar o peito abrir
e o ventre urrar

Voz, única. Minha voz? Eu? Que voz é essa? Saltei no abismo - que força sonora é essa que nele ressoa? Que ressoa no vazio imenso e ínfimo de estar aqui, de viver agora, que voz é essa? 
se a atenção

é o que dá pra pegar

cantar pra ela

Ali conheci uma outra das vozes que habitam minha voz; como os outros do grupo conheceram suas outras vozes. Como o grave abissal de Isadora, ou o agudo poderoso de Bruna, ou o grito catártico de Paola, ou o agudo leve, quase pluma, de Alexandre - palavras para experiências, o que é possível em um texto. Sempre através do movimento, o corpo inteiro participando da ação, da voz, por movimentos e imagens que abriam pontos específicos de bloqueio em nós; sempre com a escuta atenta e generosa de Paula, descobrimos nossas muitas vozes e, com elas, lugares diversos de criação.

Não há exatamente um único lugar de criação, me parece. A cada vez que atingíamos algo assim era completamente diferente - tanto o caminho como o próprio lugar. Atingir a "mesma" voz levava a lugares, a estados diferentes - e buscar o mesmo estado, em outro momento, era encontrar novamente a diferença. Mas o esvaziamento, por outro lado, era recorrente. Um estar entre.

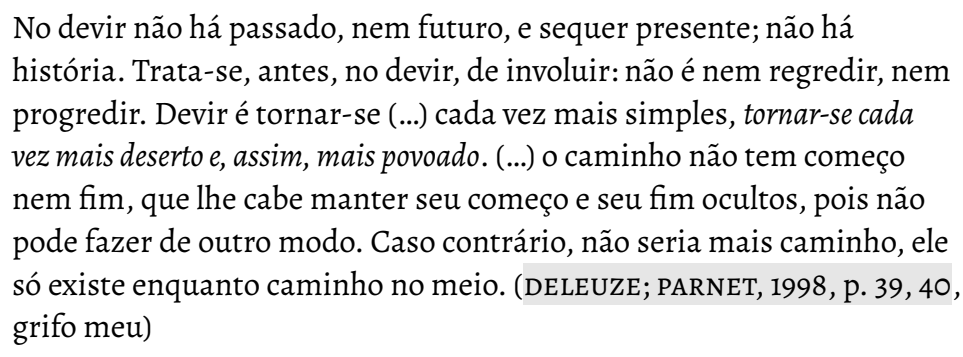
história. Trata-se, antes, no devir, de involuir: não é nem regredir, nem progredir. Devir é tornar-se (...) cada vez mais simples, tornar-se cada vez mais deserto e, assim, mais povoado. (...) o caminho não tem começo nem fim, que lhe cabe manter seu começo e seu fim ocultos, pois não pode fazer de outro modo. Caso contrário, não seria mais caminho, ele só existe enquanto caminho no meio. (DELEUZE; PARNET, 1998, p. 39, 40, grifo meu)

Mas como criar nesses lugares?

\title{
2.8 O caminho do encontro
}

\author{
finíssima areia \\ sobre as dunas macias \\ tempestade de ar
}

Além do trabalho conduzido por Paula Molinari, ao longo da residência Paulo Rios conduziu ateliês de criação conosco: períodos (uma manhã ou uma tarde) em que nos dedicávamos a criar algo com tudo que descobríamos. Com a condução de Paulo, começamos por improvisações - cada vez guiadas por uma das pessoas do grupo - e aos poucos compusemos conduções (ou seja, feitas antes das improvisações) para tais fluxos.

Com isso, logo percebemos que trazer uma determinada voz exigia fazer também os movimentos que nos levaram a ela: apoiar o osso sacro (base da coluna, no quadril) no punho de outra pessoa enquanto anda; ser puxado para trás pelo ventre enquanto 
se tenta andar para frente etc. Movimentos que, improvisação a improvisação, a cada condução que compúnhamos, iam participando cada vez mais do que fazíamos.

Até se tornarem uma linha essencial do fluxo. Foi assim que, na noite de 15 de agosto (apenas o segundo dia), em uma mesa a céu aberto do hostel onde estávamos hospedados, compusemos juntos uma sequência de vozes-movimentos; aliás, como as imagens que surgiam no trabalho de Paula nos ajudavam a trazer as vozes - como monstro, duende ou ilha difônica, p. ex. - , posso dizer que era uma sequência de vozesimagens-movimentos, em uma composição-dramaturgia em que as imagens eram também personagens. Não tanto uma história a ser entendida; muito mais, um encontro de vozes-imagens.

Com a orientação dos professores, trabalhamos essa sequência - essa peça - nos períodos do ateliê de criação (16, 17, 19 e 20 de agosto). A ideia inicial era apresentar essa peça aos alunos do curso Licenciatura em Linguagens e Códigos/Música da UFMA (campus São Bernardo), onde Paula Molinari e Paulo Rios lecionam, na manhã do dia 23 de agosto; mas por dificuldades com o hostel, na noite de 22 de agosto, não pudemos descansar o suficiente, e os professores acharam melhor que usássemos a manhã seguinte como descanso. Assim, em 24 de agosto, último dia da residência artística, chegamos a um fluxo mais bem-acabado da peça, e a apresentamos aos professores.

Não era bem uma peça de música; mas também não era teatro; talvez não fosse exatamente performance (no sentido dado pelas artes visuais e cênicas de que falei antes, cf. seção 2.6). Um grupo com pessoas da música (eu e Alexandre), do teatro e da dança (Isadora), das artes visuais (Bruna e Paola) e da performance (Paola) — o que sai disso? Ou, talvez, aquela peça fosse música $e$ teatro $e$ performance. Entre. Não que as categorias interessem tanto, porque ali nem ocorriam.

$$
\begin{aligned}
& \text { voz-corpo } \\
& \text { abdômen ventre } \\
& \text { vento que passa }
\end{aligned}
$$

Essa não foi a única criação que fizemos juntos. Como contrapartida da residência artística, ficou combinado que faríamos um compartilhamento de práticas e processos com os alunos do curso que citei da UFMA, nos dias 22 e 23 de agosto. Depois de algumas discussões, decidimos com os professores que no dia 22 faríamos uma conversa sobre os processos que cada um de nós vinha desenvolvendo, e no dia seguinte traríamos algo de nossas práticas.

Mas como falar dos nossos processos? Cada um de nós passou pelo momento de desistir de falar, de achar melhor não, já que nossos processos não eram lá grande coisa. E não eram mesmo. Foi nessa fragilidade, nessa insegurança em que estávamos, que conhecemos os alunos da UFMA - e foi esse estado que justamente criou um vínculo entre nós. Porque também éramos - somos - alunos; e assim como nós 
tínhamos medo de apresentar, eles também receavam em mostrar seus próprios trabalhos. De qualquer forma, mostramos processos (em áudio, vídeo, imagens) muito diferentes entre si, e falamos também de seus problemas, do que não corria como o esperado. Na figura 11 e em https: / / youtu . be/PbkVIR9RRQA (acesso em 27 nov. 2020), está disponível o registro ${ }^{27}$ da comunicação que fizemos nesse dia.

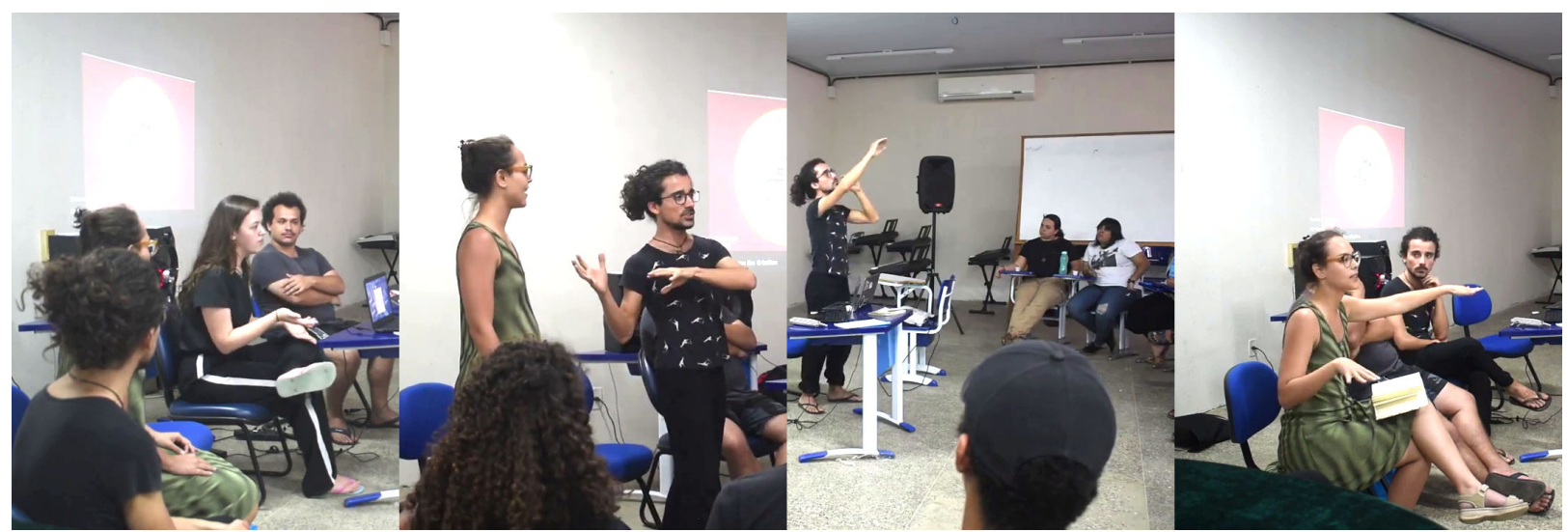

Figura 11: Comunicação do grupo da residência artística aos alunos da UFMA, no dia 22 de agosto de 2019, no campus São Bernardo. Disponível em https : //youtu . be/PbkVIR9RRQA (acesso em 27 nov. 2020).

Para o dia seguinte, tínhamos a dúvida: como compartilhar nossas práticas em apenas uma tarde, sendo elas tão diferentes entre si? Sabíamos que achar uma coerência entre elas seria impossível - e nem era o caso. Eu desejava remontar Respire de alguma forma, a partir do que havia acontecido tanto no IA-Unesp em junho daquele ano (cf. seção 2.6) como em 2018 - com aquele mesmo grupo de pessoas. O grupo então propôs que as práticas de cada um fizessem parte de uma oficina com os alunos da UFMA, que terminasse com a escrita-desenho da respiração feita por eles.

Foi assim que delineamos juntos um caminho de sutilização e abertura das sensações do corpo. Quanto aos materiais, teríamos que comprá-los em São Bernardo; na papelaria que encontramos, o que nos pareceu mais adequado como suporte (dada a quantidade de pessoas que participaria) foi o TNT (tecido não tecido) amarelo, e para o desenho, gizes de cera bem pigmentados e em boa quantidade. Em uma sala grande do prédio do curso citado, no campus São Bernardo da UFMA, fixamos faixas grandes do TNT, no chão e em uma das paredes, em uma disposição que permitisse o movimento das pessoas durante a performance.

Bruna e Alexandre começaram a oficina: mostraram imagens cada vez menos cotidianas, pedindo que os alunos - as pessoas — os nomeassem de forma livre. Depois, pediram que desenhassem os sons que ouvissem (muitos feitos com nossa própria voz e corpo), cada um em uma folha de papel e de forma livre, como uma anotação para lembrar depois. Ao colocarem uma música eletroacústica para tocar,

${ }^{27}$ Nesse registro, não está presente a fala de Paola, devido a um problema técnico com a câmera; na ocasião, ela montou, no corredor que levava à sala da comunicação, uma instalação em que dois vídeos seus, de sua pesquisa com entrevista dos espaços através da voz e do corpo, eram projetados nas paredes. 
pediram que desenhassem os sons enquanto ouviam. Era interessante ver como aos poucos as pessoas deixavam de buscar o certo, o mais correto, e simplesmente desenhavam. Então, os dois pediram que as pessoas sentissem o lugar onde estavam, dando uma palavra para uma dessas sensações, e sentindo os contrastes entre lugares e sensações diferentes.

Depois, sem interrupções, Paola pediu que todos se distribuíssem pelo espaço, mas próximos uns aos outros, sentados ou deitados mas confortáveis, e que fechassem os olhos. Ela então nos deu alguns objetos - pedras e tecidos de diferentes tamanhos e texturas, pedaços pequenos de galhos e folhas secas - e nos conduziu a deixálos sobre as pessoas, em suas mãos, pés, partes do rosto. Com outros tecidos, produzíamos às vezes vento sobre as pessoas, e às vezes as tocávamos levemente com garrafas de água fria e pedaços de tecido. Com isso, outras sensações entravam no jogo: pesos, texturas, temperaturas, densidades, durezas.

Isadora, então, conduziu uma observação interna do corpo - seus próprios pesos, densidades, espaços - através da atenção direcionada tanto a cada parte como às sensações e ritmos do corpo. Organizando o grupo em duplas, pediu que, ora um ora outro, movessem as articulações dos braços e pescoço uns dos outros, sentindo seus pesos e direcionamentos, e depois passassem levemente a ponta dos dedos, como que limpando, por toda a extensão da coluna da outra pessoa. Indicou também às duplas que pressionassem o quadril, depois os pés da outra pessoa para o chão, por alguns segundos, para que essa sentisse esse peso nos pés. Então, mudando as duplas, conduziu a atenção para a respiração através das mãos.

A partir disso, pedi que respirassem com um pouco mais de profundidade, e, com isso, soltassem a voz. Nesse momento, percebi que havia uma certa tensão entre as pessoas, como um receio do que deveria ser feito. Quando uma das pessoas deu uma pequena risada, incentivei o riso: ele também é voz, e das mais soltas - e todos riram. Desse riso, e dessa voz que surgia da respiração, pedi que se movessem com aquele som pelo espaço, livremente. Já havíamos distribuído pelo chão, os gizes de cera; então demos as instruções para a performance.

O giz só toca o TNT quando você move o ar - puxa ou solta. Se precisa tirar o giz do tecido, você não move o ar.

Com isso, tanto os alunos da UFMA como parte do grupo - exceto eu, já que preferi ficar de fora - escreveram-desenharam suas respirações, de início apenas na faixa de TNT fixada na parede, mas depois se movendo pelo espaço a partir da disposição das outras faixas no chão. Como havia vários gizes, quando um acabava as pessoas podiam pegar outro; e, depois de algum tempo, dissemos que os desenhos podiam também ser lidos com a respiração, tentando passar por todas as faixas. A performance coletiva durou em torno de quinze minutos, e ao final as faixas de TNT estavam preenchidas de linhas, de traços de diversas cores, e todos observando a última pessoa que ainda tinha 
um giz nas mãos, e que seguiu desenhando e respirando até que o giz sumisse debaixo de seus dedos.

O registro dessa oficina foi feito em uma sequência de sete vídeos, devido à impossibilidade das câmeras em gravar mais de trinta minutos consecutivos. A seguir, relaciono cada parte da oficina com seus vídeos correspondentes, já que elas não coincidem exatamente com as divisões dos vídeos.

- Bruna e Alexandre: disponível na figura 12 e em https://youtu.be/PjQQh7PYlm0, https://youtu.be/12dL4YliScI e https://youtu. be/CURXP1USM7A (acesso em 27 nov. 2020);

- Paola: disponível na figura 13 e em https: / / youtu . be/CURXP1USM7A e https://youtu. be/ZrMMEDSCsBs (acesso em 27 nov. 2020);

- Isadora: disponível na figura 14 e em https : //youtu . be/ZrMMEDSCsBs e https://youtu. be/qT6LxsF7Qqo (acesso em 27 nov. 2020);

- Eu: disponível na figura 15 e em https://youtu.be/qT6LxsF7Qqo e https :/ /youtu.be/GmFr46FfLmk (acesso em 27 nov. 2020);

- Performance coletiva: disponível na figura 16 e em https : / / youtu . be / _rCWsieWUhI (acesso em 27 nov. 2020).

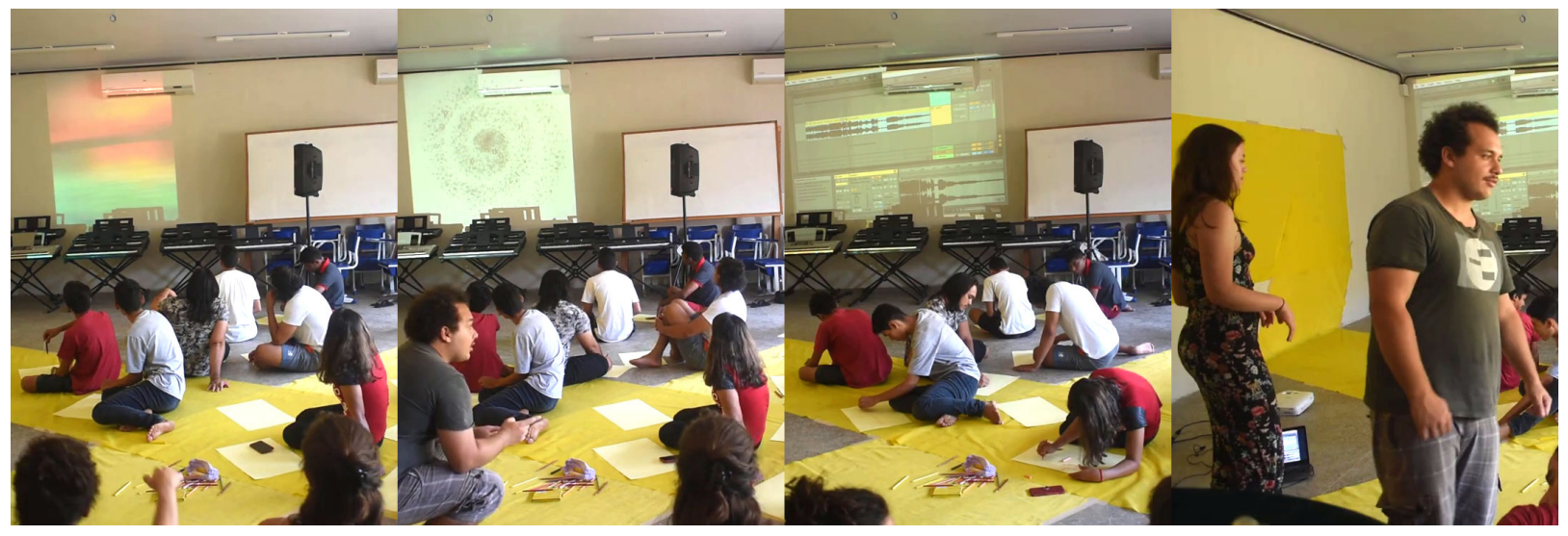

Figura 12: Bruna e Alexandre conduzem a primeira parte da oficina, para os alunos da UFMA (São Bernardo). Disponível em https : //youtu. be/PjQQh7PYlm0, https://youtu. be/12dL4YliScI e https : //youtu. be/CURXP1USM7A (acesso em 27 nov. 2020).

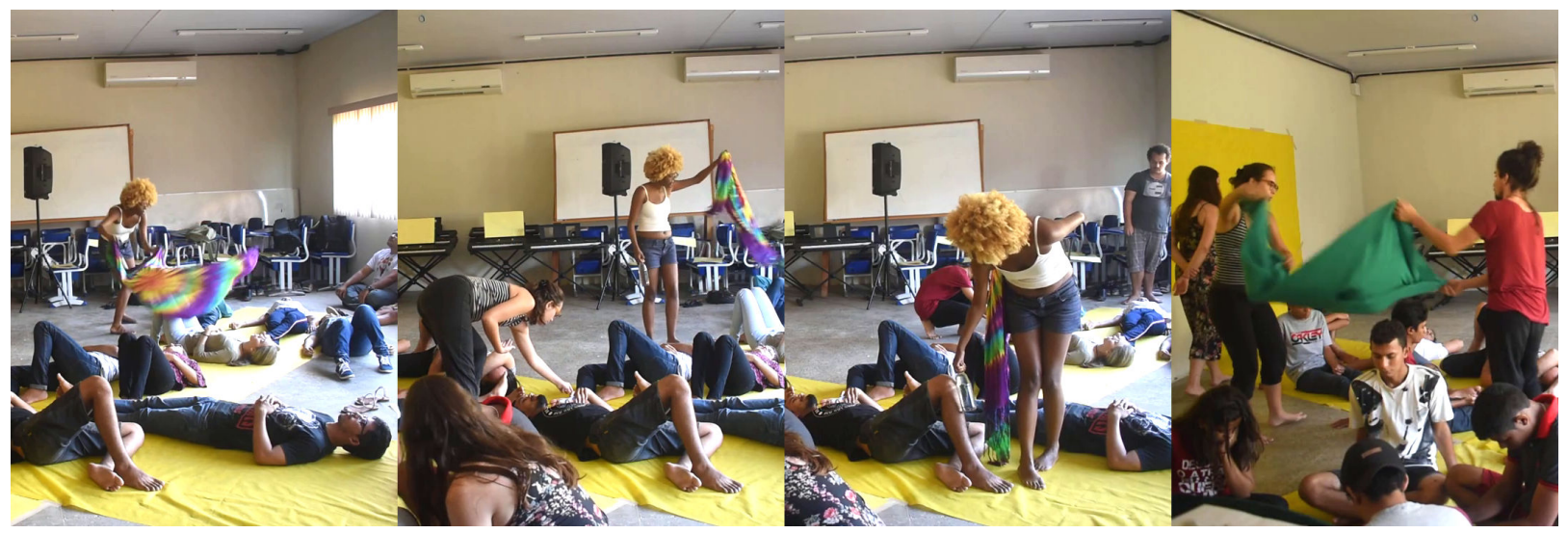

Figura 13: Paola conduz a segunda parte da oficina, para os alunos da UFMA (São Bernardo). Disponível em https://youtu. be/CURXP1USM7A e https ://youtu. be/ZrMMEDSCsBs (acesso em 27 nov. 2020). 


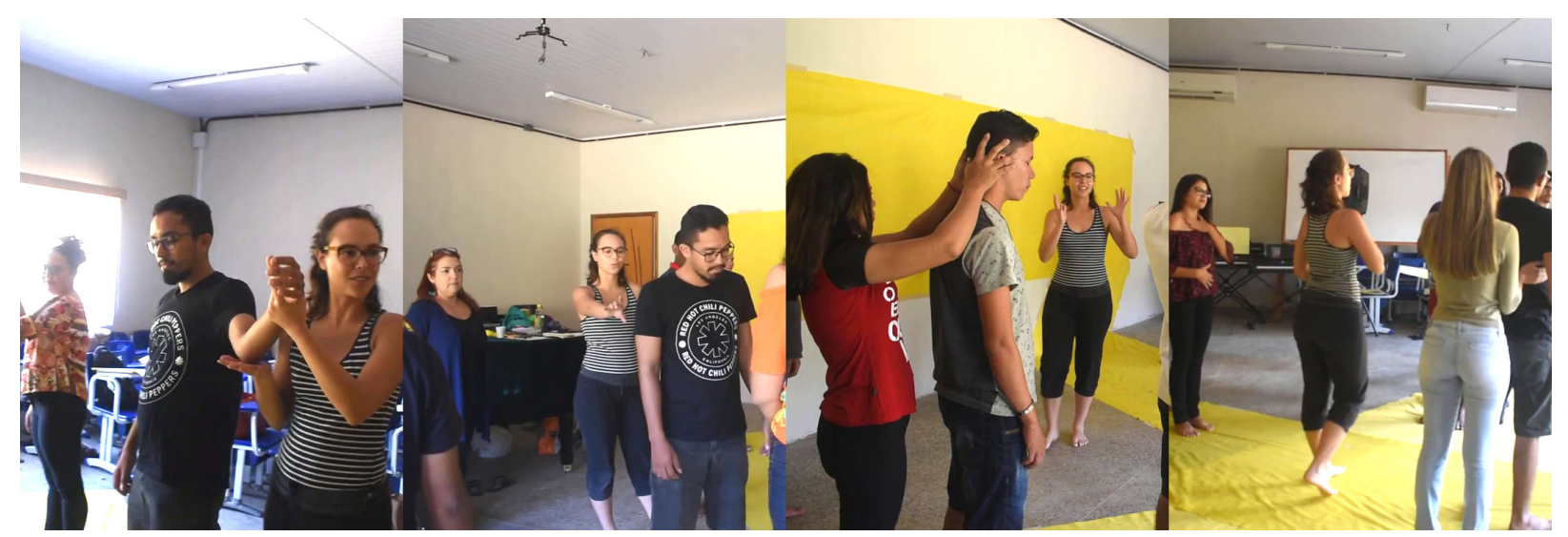

Figura 14: Isadora conduz a terceira parte da oficina, para os alunos da UFMA (São Bernardo). Disponível em https://youtu.be/ZrMMEDSCsBs e https://youtu.be/qT6LxsF7Qqo (acesso em 27 nov. 2020).

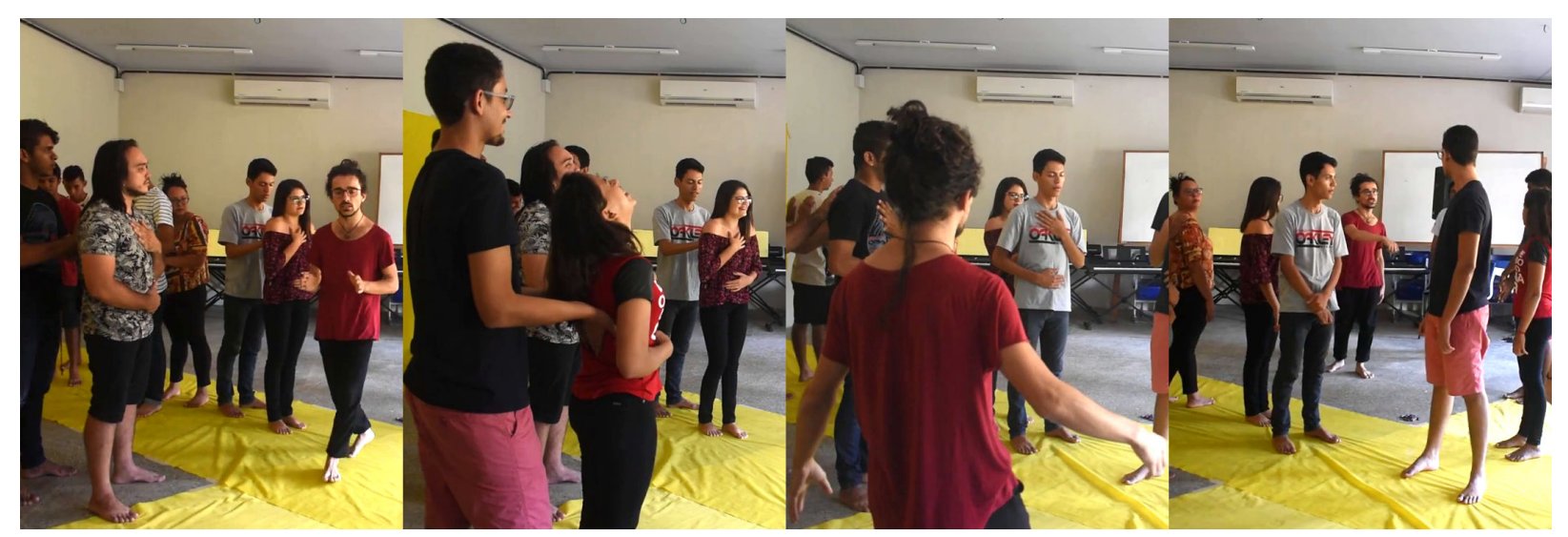

Figura 15: Conduzo a quarta parte da oficina, para os alunos da UFMA (São Bernardo). Disponível em https ://youtu . be/qT6LxsF7Qqo e https ://youtu. be/GmFr46FfLmk (acesso em 27 nov. 2020).

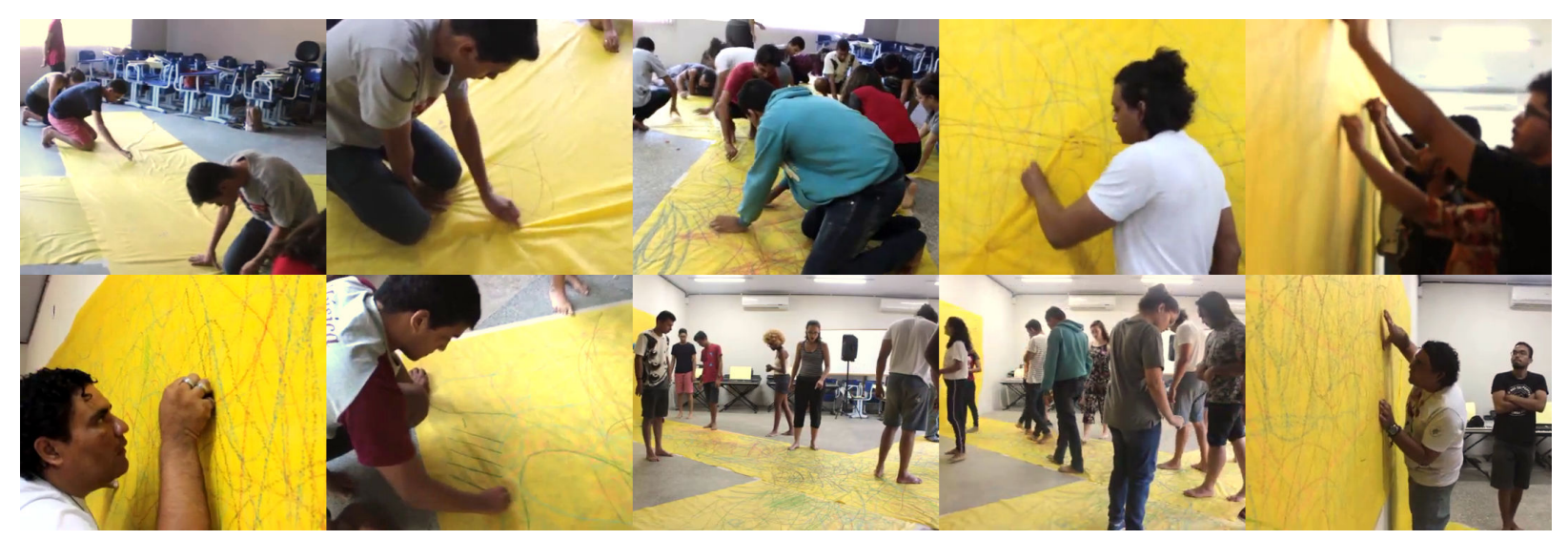

Figura 16: Performance coletiva Respire, com os alunos da UFMA (São Bernardo). Disponível em https ://youtu.be/_rcWsieWUhI (acesso em 27 nov. 2020).

Depois que a performance tinha acabado, para encerrar o fluxo, pedi que fizéssemos uma roda e batêssemos uma só palma, sem indicação e juntos. Depois de um intervalo, conversamos com alguns dos alunos - boa parte precisou ir embora devido ao horário de seus ônibus - sobre o que havíamos vivenciado. A conversa foi muito boa, apesar de curta; e logo depois ainda conhecemos trabalhos em desenvolvimento por alguns alunos, em luteria experimental ${ }^{28}$.

${ }^{28}$ A luteria experimental é a prática de construir instrumentos musicais não tradicionais, a partir da 
Foi a primeira vez que não participei da performance de Respire. Como já disse, quis ficar de fora, tanto para eventualmente dar instruções adicionais quando alguém tivesse dúvidas, como para ver e ouvir outras pessoas fazendo-a. A princípio, quando todos estavam traçando suas respirações na faixa da parede, achei que talvez nossa oficina não tivesse dado "certo"; mas logo percebi que não era essa a questão. Cada um dentro de sua vocalidade, sua corporalidade, sua voz, eles se entregaram à performance de jeitos tão diversos e tão bonitos de se ver. Como grupo, estávamos felizes porque conseguimos abrir um espaço de criação, para nós e para eles, naquela tarde.

Mas, apesar de descrever aqui o que foi aquela oficina e performance, é difícil colocar em palavras o que sentimos como grupo. A troca com os alunos, com os professores (incluída a Profa. Pamela Almeida, da UFMA, que nos ajudou a encontrar os materiais), com o campus, a cidade de São Bernardo... As conversas que tivemos com Paula Molinari, Paulo Rios e Pamela Almeida nas viagens ao campus, em que discutimos criação, composição, performance, teatro, voz, e como alcançar a vida, a potência da vida nessas atividades - como? Encontros de muitas vozes, que nos lançaram em movimento, em um devir que correu por nós por semanas, meses depois.

\author{
por cima de mil céus \\ nuvens brincam e constroem \\ palácios de vapor \\ na garganta a cajuína \\ no corpo ainda o voar
}

O que é compor com a voz, criar com a voz? Em que lugar, lugares, isso acontece? Como acessar isso? A voz cria? As vozes? Encarar a intuição como trabalho, com método - como nos disse Paulo Rios numa conversa em 21 de agosto de 2019 -, não porque ela seja algo divino, inspiração que conduz e faz tudo, não. Encarar a intuição como parte fundamental do processo criativo e da performance, e descobrir os meios de aguçá-la, de estimulá-la. Descobrir seus horários, seus caminhos. Traçar a respiração no vazio, abrir aos poucos o pequeno abismo que nos leva a esse estado leve, esse pequeno vazio onde uma outra voz pode surgir.

\author{
sentir o voo \\ entre a terra e o longe céu \\ sendo grão de areia \\ cada galho e folha \\ cada pequenina gota \\ brota caminhos
}

experimentação com materiais e sonoridades. 
escrever-fluxo

a mão que curva e segue

o ar que em mim passeia

esquecer o fôlego

por um longo tempo curto

ouvir o que passa

esquecer o fôlego

por um longo tempo curto

ver o que passa

deixar o peito abrir

por um curto tempo longo

sentir o que se passa

deslizar o ar

do ventre até a garganta

do fundo ao topo

cada carne e osso

por um longo tempo curto

sentir o que se passa

cada sopro e fluido

por um curto tempo longo

deixar a mão correr

entre o carvão preto

e as fibras entrelaçadas

nasce a mancha-sopro

entre o peito fundo

e a pele que ouve e vê

nasce a voz-mancha

entre o sopro suspenso

e o correr das vozes muitas

nasce a criação

Se sua leitura fez o salto que sugeri na seção 2.5 e já percorreu os capítulos 3 e 4, salte novamente para a seção 5. 


\title{
3 Mirante, OU UM HORIZONTE A VOZES MUITAS
}

\author{
correm pássaros \\ vento frio da tarde \\ cinza de imagens
}

Tarde ampla de meio de outubro. Aqui, a Serra da Mantiqueira reaparece, depois de semanas e semanas encoberta pelo fino pó da fumaça, do fogo que se espalhou - ou foi espalhado? - por tantas outras serras e matas, do Pantanal à Amazônia ao Cerrado. O frio, que nem é dessa época, muda as cores do sol. Se antes, com a serra coberta, ele era de um amarelo estranho, velho, empoeirado, agora volta um pouco do brilho do meio-dia - se bem que encoberto de nuvens.

Serra tão perto quanto tão longe ficou o fogo de um palco rodeado de gente. Memória representada de entreolhares, frio na barriga, fogo nos pés e nas mãos, o silêncio logo no começo de uma música ou aquele sonoro "merdaaaaaa" de preparação para o mergulho. Memória representada, porque a distância no espaço, no corpo, nas sensações acaba marcando, sulcando um tempo de intervalo tão longo, tão estranho que acabo cedendo à bela representação. Distância isolada, pandêmica.

Mergulho? Fogo? Fluxo? Que palco?

$$
\begin{aligned}
& \text { pisar os pés } \\
& \text { no chão que me recebe } \\
& \text { e sentir o céu }
\end{aligned}
$$

Um palco vazio e amplo. Mergulhar lentamente no ar denso carregado de olhares, senti-lo na pele; assoprar a pequena chama na base do ventre, e deixá-la aquecer o corpo, vértebra por vértebra; nadar no fluxo que corre aqui-agora, essa máquina de diferenças a brotar entre; sentir o palco se abrir nesse mergulho, mais amplo e vasto a cada passo.

Se é um corpo, uma voz que está nesse palco, quem é ela? Como compor, como trabalhar a composição de forma que essa pessoa, esse quem, possa pisar no palco e senti-lo amplo? Como abrir a composição à unicidade dessa voz-corpo e às imagens que ela pode fazer brotar? Como fazer composição e performance se atravessarem em suas múltiplas linhas?

E como fazer isso sem descartar a utilidade da partitura como ferramenta?

\subsection{Dos ventos que sopram}

No primeiro semestre de 2019, Jessica Gubert, clarinetista e à época mestranda em Performance, e eu desenvolvemos um processo criativo que culminou em uma peça 
para clarinetista solo. Antes de falar desse processo, coloco a seguir um texto dela sobre esse processo, seus desdobramentos e atravessamentos.

Sou mato-grossense e cresci na capital do meu estado, em Cuiabá. Além de ser uma cidade muito quente, Cuiabá tem uma diversidade e riqueza natural muito grande, estando geograficamente próxima a três ecossistemas brasileiros, a Amazônia, o Pantanal e o Cerrado. Talvez por eu crescer rodeada por tanto mato, bichos, rios, cachoeiras, como é o estado de Mato Grosso, criei uma relação muito forte com a natureza ao longo da minha vida e em especial nos últimos anos com a cidade e o entorno de Chapada dos Guimarães. Tanto é que meus amigos mais próximos sabem que meu objetivo de vida é construir uma casinha e morar em Chapada.

Atualmente moro em São Paulo para realizar o meu mestrado em Performance Musical - Clarineta na USP e foi na universidade que conheci o Neto. Entramos no programa de mestrado juntos e logo no primeiro semestre iniciamos um processo colaborativo de criação musical de uma obra para clarineta solo. O processo foi muito natural e com bastante diálogo, me recordo de marcarmos encontros semanais e no princípio ter mostrado para o Neto o repertório que eu estava estudando e as técnicas estendidas que eu estava pesquisando naquele período. Lembro que havia um interesse por parte dele de querer aprender e conhecer mais sobre a clarineta, da curiosidade em saber sobre quais sonoridades eu gostava de fazer no instrumento e de qual trecho me chamava mais atenção dentro do repertório que eu estava estudando.

Além dos aspectos musicais, no decorrer dos nossos encontros e no convívio da universidade eu fui me abrindo, relatando um pouco mais da minha vida e das minhas vivências no Mato Grosso. Comentei sobre o quanto eu gostava da natureza e principalmente da minha relação com Chapada dos Guimarães e o Pantanal. Devido a essas conversas informais, em um dos nossos encontros musicais, me recordo que ele me perguntou de qual bicho eu mais gostava. Eu achei um pouco estranho, pois as nossas conversas sempre caminhavam para um campo mais filosófico da música, do som e da arte, mas meio que do "nada" ele me perguntou qual animal eu mais gostava. Falei que eu nunca tinha parado para pensar nisso de forma tão específica assim, mas a primeira cena que me veio à mente após ele me fazer essa pergunta foi de uma tarde que eu estava no mirante em Chapada dos Guimarães.

Era um dia de semana, por isso naquela tarde havia poucas pessoas visitando o Mirante. Com isso, fiquei horas ali sozinha contemplando a belíssima paisagem, sentindo o forte vento sob meu corpo e percebendo a imensidão e a grandiosidade daquele local. Para além destes aspectos, algo que me chamou muita atenção naquela tarde foi o canto de dois pássaros. Eram dois jaós, cada um estava numa extremidade e em direções opostas, um estava mais perto de mim, por isso seu canto era mais perceptível e o outro mais distante. Percebi que o canto deles não era como a maioria dos outros pássaros que fazem vários saltos e variações rítmicas, observei que eram notas mais longas, com intervalos próximos. Notei também que havia uma relação com o espaço, além de ser o habitat natural deles, eles cantavam de locais diferentes, um mais perto e após uns segundos o outro mais distante meio que respondia e parecia que havia um diálogo de jaós ali naquele local. Aquela escuta além de divertida, foi significativa para mim, mas nunca havia comentado com ninguém, até o dia que o Neto me perguntou qual era meu animal preferido, então a imagem deste dia sobreveio na minha mente e compartilhei essa experiência com ele. 
Foi neste contexto que surgiu o nome Mirante para a nossa peça. Fiquei muito contente pelo espaço e poder trazer minhas experiências de vida e elementos da região onde cresci para a composição musical. O Neto pesquisou sobre o mirante de Chapada dos Guimarães, sobre o cerrado, sobre o jaó, suas particularidades e o seu canto. $\mathrm{Na}$ semana seguinte ele trouxe um esboço com algumas possibilidades de escrita para o canto do jaó e me lembro que a gente conversou e experimentou no instrumento várias sonoridades tentando encontrar aquela que tivesse um melhor resultado.

O Neto tem uma vivência teatral muito forte e desde o início ele sugeriu de trabalharmos para além das questões musicais e sonoras da clarineta, que criássemos movimentos corporais. Lembro que ele comentou da peça Der kleine Harlekin do Stockhausen e de como essa obra chamou sua atenção devido ao modo que o compositor trabalhou com esses elementos musicais e corporais. Eu gostei muito da ideia e decidimos ir por este caminho, mas ao realizá-la, encontramos alguns desafios. O primeiro deles foi em como anotar os movimentos na partitura, como marcar meus passos, definir a direção da clarineta se era para a esquerda ou direita, qual a inclinação do instrumento, para cima, altura do rosto ou para baixo. Todos esses aspectos foram discutidos e adaptados na busca de maneira mais idiomática e clara possível.

A segunda dificuldade foi durante o meu processo de estudo da peça. Até então, o estudo do meu instrumento tinha como objetivo resolver passagens com dificuldades técnicas, de sonoridade, articulação, afinação. Com a peça Mirante percebi que os desafios eram outros, pois além da questão musical eu precisava compreender meus movimentos corporais e criar uma nova relação no meu estudo, que valorizasse não apenas a música, mas o meu corpo também. Como eu não havia realizado nada nesta linha, esse foi um aspecto de amadurecimento e crescimento dentro da minha formação musical, entender na prática que tocar clarineta não se resume apenas em estar com a clarineta na boca, compreender que sou uma artista e que a clarineta é apenas mais uma forma de me expressar frente às diversas possibilidades. Confesso que não foi tão simples fazer essa mudança na minha cabeça e compreender que todo o meu corpo faz parte da obra musical.

Outro desafio que encontrei foi em decorar a música. Como os movimentos do meu corpo fazem parte da compreensão do discurso musical da Mirante, o fato de eu ler na partitura percebi que atrapalharia a performance. Sempre tive dificuldades em decorar o repertório e com a Mirante não foi diferente, mas tentei criar histórias, roteiros e personagens que me ajudaram a memorizar a música e os movimentos corporais da peça.

Ter colaborado com o Neto na criação da Mirante foi um crescimento enorme para mim. Um aspecto que mais me chamou a atenção foi a abertura do diálogo e o modo em que o Neto colocou as ideias, pois me senti de fato inserida e participante da criação. Com esse canal de comunicação sempre aberto, não percebi essa diferença e as relações de poder pertencentes à tradição musical entre compositor e intérprete. Minha sensação era de que nós dois estávamos criando algo e que cada um colaborava numa proporção maior naquilo que cada um faz de melhor, no meu caso o conhecimento do instrumento e de performance e do Neto com as técnicas e ideias de composição. 
Finalizamos o processo composicional da peça e a primeira apresentação foi na mostra musical da disciplina Criação e performance no repertório musical contemporâneo ${ }^{29}$. Mas tanto eu quanto o Neto pretendemos continuar esse processo artístico e aprofundar sobre as questões de performance da peça.

Jessica Gubert

\subsection{A sensação de um horizonte}

Em 2018, conheci Jessica Gubert durante o processo seletivo para o Mestrado. Ela tentava ingressar na linha de pesquisa em Performance, e eu em Sonologia; assim, entramos no mesmo período na pós-graduação, no início de 2019. Ao longo desse processo, combinamos de fazer uma peça para clarineta juntos, assim que o estresse do processo seletivo baixasse.

Na verdade, a ideia da peça veio através de outra peça: junto com o violinista Lucas Raulino, havia composto em 2018 uma peça para violino solo, Luthieria $^{30}$, a partir de imagens poéticas e sons trazidos por ele. Esse processo criativo, e seus resultados, chamou a atenção de Jessica ${ }^{31}$, que se interessou por desenvolver um processo semelhante comigo. Foi através de Raulino, que era mais próximo dela, que nos conhecemos e passamos a conversar sobre tal ideia de um processo criativo.

Até que no dia 21 de março de 2019, conseguimos nos encontrar em uma sala de estudos do Departamento de Música da ECA-USP. Nessa conversa, que durou mais de uma hora, Jessica me mostrou sons e passagens interessantes do repertório da clarineta, principalmente do século XX, além de questões técnicas e de notação do instrumento, como ela diz na seção 3.1. Ela me mostrou trechos de peças ${ }^{32}$ de Jörg Widmann (Fantasie), Luciano Berio (Sequenza IXa), Roberto Victório (Altiplano), Igor Stravinsky (Três peças para clarineta), além do arranjo de Lamento Sertanejo (de Dominguinhos) feito pelo quinteto Viajando pelo Brasil (com o qual ela iria tocar), e trechos do Concerto para clarineta em lá maior de W. A. Mozart. Nesses trechos, destacou

${ }^{29}$ Essa disciplina da pós-graduação fazia parte do Laboratório de Interpretação e Criação Contemporânea, citado ao longo do capítulo.

${ }^{30}$ Raulino e eu discutimos o processo criativo de Luthieria em uma comunicação em congresso (MATTOS NETO; RAULINO, 2019). A peça foi tocada por Raulino no seu Recital de Conclusão de Curso em junho de 2019, no Auditório Olivier Toni, além de em outros lugares na segunda metade de 2018. Vídeo disponível em https : //youtu . be/gf6F2NXCp64 (acesso em 22 out. 2020).

${ }^{31}$ Nesse capítulo, como em outros, opto por usar o primeiro nome de Jessica Gubert em vez de seu sobrenome para retomá-la no discurso verbal. Assim, aumento a proximidade entre ela e o texto, embora, com isso, acabe por não seguir as diretrizes de um texto acadêmico.

${ }^{32}$ Há vídeos disponíveis de Jessica tocando algumas dessas peças: Altiplano de Victório (em https : / /youtu . be/Phc JtLuwkKI, acesso em 28 out. 2020), Lamento Sertanejo de Dominguinhos/Viajando pelo Brasil (em https : //youtu . be/tunMGp9u3nE, acesso em 28 out. 2020) e Fantasie de Widmann (em um concurso posterior à estreia do processo desse capítulo. Vídeo disponível em https://youtu . be/BhTEc41c1ho, acesso em 28 out. 2020). 
o uso de glissando, multifônicos, sons de chave, frullato, quartos de tons, trinados de multifônicos, e outras técnicas.

Assim, seguimos de início em um levantamento de possíveis materiais e referências composicionais, e de potências e problemas técnicos. Até que, ao experimentarmos como seria um pássaro grave na clarineta, ela falou do jaó: um pássaro típico da região de Cuiabá, Mato Grosso, onde Jessica cresceu. Em vez do canto agudo e ágil que normalmente imaginamos - e que podemos considerar como presente, por exemplo, nas Três peças para clarineta e também na Sagração da Primavera (nos sopros) de I. Stravinsky -, em vez disso, o canto do jaó é grave e longo, quase sem inflexões melódicas; e pode ser ouvido ao longe no fim da tarde, tanto em Cuiabá como na Chapada dos Guimarães.

$$
\begin{aligned}
& \text { pés } \\
& \text { terra vasta } \\
& \text { amplo horizonte } \\
& \text { aberto em volta }
\end{aligned}
$$

Chapada dos Guimarães, centro geodésico da América do Sul. Vasta extensão de mata, pássaros, rios e rochas. Do mirante alto, a visão alcança longe o horizonte. É desse lugar que Jessica se lembrou ao falar do jaó, de um fim de tarde em particular, em que se decidia se continuaria em São Paulo para ingressar no Mestrado na USP. Sozinha no mirante, numa terça ou quarta-feira de algum lugar, o mundo desmoronando já naquela época - com a perspectiva sombria da eleição de 2018 - o pôr-do-sol vermelho e o vento leve, e então...

$$
\begin{aligned}
& \text { jaó canta longe } \\
& \text { vento corre, sol caminha } \\
& \text { outro jaó responde }
\end{aligned}
$$

Um canto que atravessa o vale, que reverbera na mata e alcança o mirante, lento, calmo, grave; um canto de jaó se mistura com o vento, com o sol vermelho, com o horizonte gigantesco, se espalha e se derrama pela Chapada. E do outro lado do mirante, de novo, outro jaó.

Como Jessica me disse naquela conversa de 2019, esse lugar é para ela mais do que uma vista bonita: "me sinto muito em casa, lá. É um lugar que eu faço questão de ir sempre. Eu vou pra Cuiabá, você pode saber que eu estou lá, é aí" ${ }^{33}$. Em toda a conversa anterior a esse relato, sobre técnicas e repertórios e sons interessantes, era a clarinetista que falava; mas, ao falar da Chapada dos Guimarães e do jaó, algo mais

${ }^{33}$ Essa citação, assim como o pequeno relato anterior da tarde passada no mirante, foram anotados a partir de gravação em áudio da conversa, feita com consentimento de Jessica, além do relato de Jessica na seção 3.1 . 
humano apareceu: uma sensação, um emaranhado de sensações e memórias que não era de uma clarinetista apenas, mas da Jessica. Uma unicidade.

Foi a partir dessa experiência dela no mirante que desenvolvemos o processo criativo e a peça resultante. As técnicas, repertórios e sons discutidos naquela ocasião foram importantes, como falo mais adiante; mas o caminho poético, a imagem poética do mirante foi realmente a guia do processo.

Por quê? Essa imagem, esse emaranhado poético não era apenas imaginado, era uma sensação concreta vivenciada por Jessica. Considerando que a performance seria feita por ela, era importante partir de algo que já a atravessasse, que já fizesse parte de seu universo interno. E, embora eu ainda não conheça a Chapada dos Guimarães e aquele mirante, cresci em Pindamonhangaba, no Vale do Paraíba: os mirantes da Serra da Mantiqueira e da Serra do Mar são também uma sensação muito presente para mim.

Mas como fazer surgir um mirante no palco?

Distância imensa do horizonte, uma amplitude gigantesca do espaço, e uma pequenez do nosso corpo e do nosso ser que não é opressora, mas que acalma. Ao lembrar dos mirantes que conheço, são essas as sensações mais marcantes. Um primeiro problema: como deixar o horizonte mais distante, se normalmente o palco e o público, a situação de performance, ocorre dentro de um prédio fechado? Como ampliar esse espaço?

ouvir o vento

do ventre mais profundo

ao horizonte

Imaginei que a respiração, novamente ela, poderia ajudar. Se em 2018 havia experimentado como ampliar a sensação do tempo através da respiração (como descrevo na seção 2.5), dessa vez talvez pudesse fazer algo semelhante quanto ao espaço. Assim, depois daquela conversa, compus uma primeira versão da peça, começando com respirações dentro da clarineta cada vez mais intensas, culminando em uma movimentação da ponta da clarineta para cima (com a inspiração) e depois para a posição ordinario (apontada para baixo, com a expiração), como pode ser visto no primeiro sistema ${ }^{34}$ do manuscrito da figura 17.

Com isso, tentava trazer algo da peça Beira-mar ${ }^{35}$, especificamente da tuba: ao expirar e também inspirar dentro da tuba, Caserta (o tubista) ia aos poucos alcançando um estado meditativo; e o som da respiração, que era amplificado pelo instrumento,

${ }^{34}$ No primeiro sistema do manuscrito da figura 17, há a seguinte notação: um círculo com um ponto no meio para a inspiração; um xis para a expiração; uma linha grossa que marca a duração relativa de cada ação; "cima" ("c.") e "ord." (de ordinario) para posição da clarineta — se apontando para cima ou na posição habitual. Abordo essas notações mais à frente.

${ }^{35}$ A peça Beira-mar, já citada no capítulo 2, foi composta em 2018 junto a Raphael Caserta (tubista) e Rafaela Lopes (harpista). 


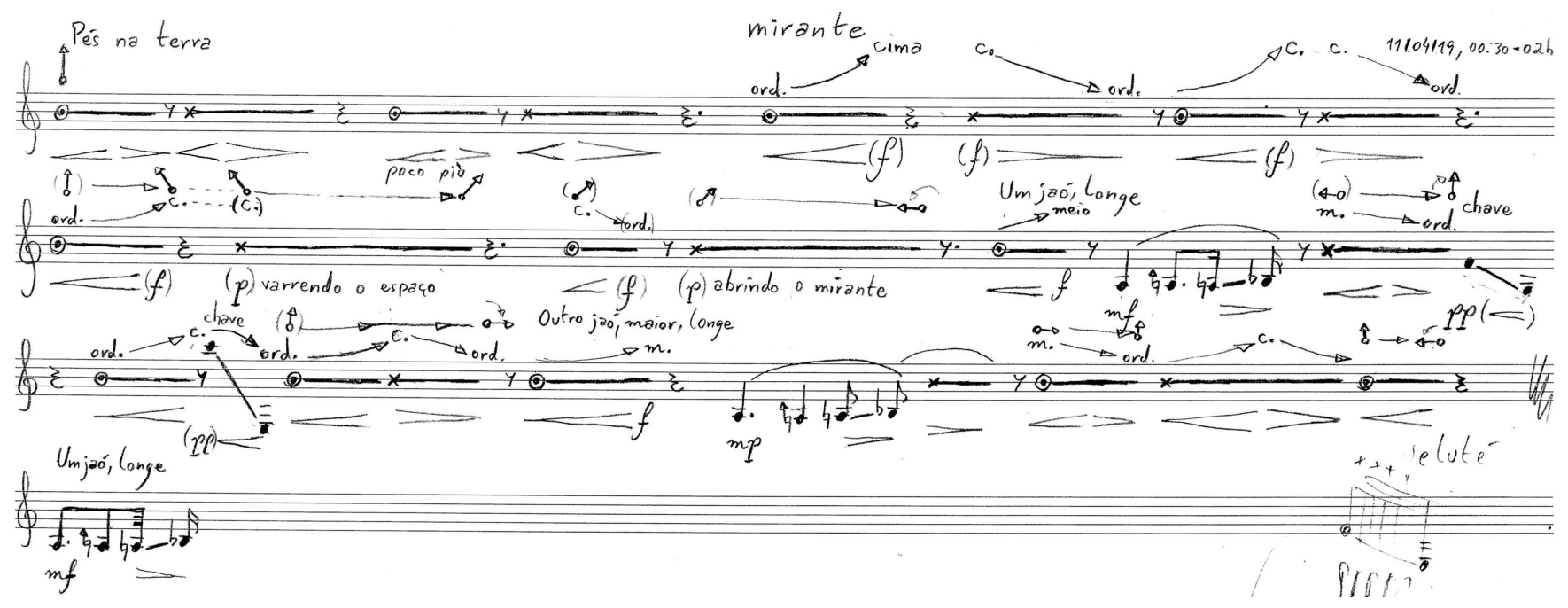

Figura 17: Primeiro manuscrito da peça Mirante, escrito em 11 de abril de 2019. Na base da imagem, à direita, pode ser vista uma anotação de conversa posterior com Silvio Ferraz.

tinha também a potência de conduzir a respiração do público. Uma ressonância de respirações que ia alterando a sensação do fluxo do tempo.

Mas com a clarineta, por outro lado, não é possível amplificar a respiração a ponto dela alterar a percepção do tempo - ou do espaço, no caso. Respirar dentro da clarineta gera um som bem mais suave e também um pouco mais agudo, que não me pareceu envolver quem ouve o suficiente. Em suma, não era possível replicar aquela ressonância de respirações nesse processo. Como, então, ampliar o espaço?

Ao tentar escrever o manuscrito da figura 17, me deparei com essa dúvida, e então imaginei que talvez o gesto pudesse criar essa ampliação: gestos vastos, talvez lentos, que percorressem o espaço de alguma forma. Mas pensar em gestos não é algo muito natural para alguém cuja principal formação é a música, não a dança ou algo do tipo, ainda mais porque esses gestos seriam feitos com a clarineta nas mãos: sou pianista, não carrego meu instrumento nas mãos! E, afinal, se o que eu queria era transformar a sensação do espaço, era importante experimentar com o corpo o que podia fazer isso:

\footnotetext{
Qual é a diferença exata entre os braços pendentes na vertical e quando estão na horizontal? (...) Conforme trabalhamos, devemos nos lembrar de que não somos máquinas e que precisamos descobrir exatamente como cada mudança no corpo age em nosso interior. (OIDA, 2007, p. 51)
}

Assim, usei uma colher de pau comprida que tinha em casa para simular uma clarineta, e comecei a experimentar no meu quarto diferentes gestos. Para acalmar a ansiedade em encontrar soluções, foquei minha atenção na respiração, até que, respirando cada vez mais leve e profundamente, o primeiro gesto surgiu: erguer a ponta da colher de pau para cima com a inspiração, e baixá-la lentamente com a expiração. Depois de algum tempo, quis enxergar o horizonte, não apenas à minha frente, mas em volta de mim, e então surgiu o segundo gesto: inspirar erguendo a colher de pau para um lado, e expirar varrendo o espaço até o outro lado. Varrendo todo o ruído do espaço, de modo a criar algum vazio interno. E depois, o terceiro gesto: com a clarineta (colher de pau) na posição habitual, expirar abrindo o mirante à minha 
frente.

Ao dizer que os gestos "surgiram", não é porque não houvesse nenhuma intenção ou intervenção intelectual — havia ambas. Mas, em vez de colocá-las em primeiro plano, conduzindo o tempo todo a composição dos gestos, tentei experimentar movimentos e ações sem saber ao certo o que aconteceria, a partir de um esvaziamento interno. Esse vazio, como nos fala Brook (2000, p. 4, 18-19), é fundamental para que algo novo, imprevisível, possa acontecer. Naturalmente não era possível um esvaziamento muito profundo: estava no meu quarto, em meio a mobília, livros, cadernos, roupas... Ainda assim, focando a atenção na respiração (e também organizando o espaço de modo a diminuir as distrações), pude descobrir gestos simples com alguma potência.

(E, claro, outros gestos surgiram naquele momento, de que não me lembro e que descartei por motivos diversos. Não me lembrar deles, aliás, talvez seja uma pista de que não eram tão potentes assim.)

Assim, esse "surgimento" dos gestos, embora pareça aqui no texto um ato muito "espontâneo", é na verdade resultado de um processo, algo semelhante ao que nos diz o compositor Brian Ferneyhough (1993, p. 33):

Todos os sistemas estruturantes são, até certo ponto, arbitrários
e espontâneos, tanto quanto espontaneidade não é nada mais
que o estágio final de um ritual geralmente longo e intenso de
autoprogramação [ou autocondução] da parte do compositor ${ }^{36}$.

Assim, a partir daqueles gestos, escrevi o primeiro e metade do segundo sistema daquele manuscrito, e então continuei a escrita juntando os elementos dos gestos (posição vertical da ponta da clarineta e direção de giro do corpo) com a transcrição do canto do jaó - feita por Jessica naquela primeira conversa. Trabalho parte intelectual, parte experimental (com a colher de pau), compus algumas linhas brincando com os gestos, os jaós e o relato dela: um jaó longe à esquerda; outro maior, mas mais longe ainda, à direita; e o primeiro respondendo, um pouco mais longe que de início. Um pequeno experimento para levar ao encontro seguinte com Jessica.

No dia 11 de abril de 2019, tivemos um ensaio em que lemos juntos o manuscrito e tentamos encadear um fluxo com ele. Apesar da dificuldade inicial com a respiração dentro da clarineta e com os gestos - em grande parte por conta da notação mal resolvida à época - Jessica comentou que parecia haver um tempo certo para aquelas respirações, tornando-as mais naturais. Na verdade, não tanto um tempo, já que era possível fazê-las mais lentas, rápidas, longas, curtas etc. Era mais uma mudança de foco: em vez de se atentar tanto para notas, focar em algo mais interno e corporal, como a respiração. E, da minha parte, percebi que justamente nessas mudanças de foco a presença dela também se modificava: mais calma, pisando um pouco mais com os pés no chão.

36 "All structuring systems are, to some extent, arbitrary and spontaneous, just as most spontaneity is nothing but the final stage of a frequently lengthy and intense ritual of self-programming on the part of the composer." 
Essa mudança de presença me fez lembrar do que ouvi e presenciei algumas vezes em outros processos criativos, não em música mas em artes cênicas: se uma atriz ou ator está de fato presente, e se ela ou ele enxerga de fato a cena à sua frente, então o público também enxergará ${ }^{37}$. Ou, como nos fala o ator japonês Yoshi Oida (2007, p. 72),

Para o ator, o problema semelhante é manter a presença quando se está diante de um público. Embora o público não possa explicar com palavras, ele sente a energia do ator e, para as pessoas, esse é um dos principais prazeres do acontecimento teatral.

Se não havia aquela ressonância de respirações que era possível com a tuba de Caserta em Beira-mar, por outro lado, aqui, a respiração de Jessica dentro da sua clarineta modificava a sua presença. E se essa mudança pudesse ser aprofundada, talvez o horizonte do mirante aparecesse através dela.

Mas naquele manuscrito não havia apenas respirações, mas também gestos, sons de chaves e três jaós que apareciam separados. Um horizonte amplo, da mesma forma, é algo importante em um mirante, mas não é a única coisa que há ali. Naquele ensaio de 11 de abril, Jessica e eu percebemos que apenas tocar as transcrições dos jaós no meio dessas respirações e gestos não era suficiente para que os próprios jaós surgissem: algo mais era necessário.

\subsection{Muitos e vários cantos}

Cerca de duas semanas depois daquele ensaio de 11 de abril, tive uma conversa com Silvio Ferraz em que, entre outros temas debatidos, falei do processo com Jessica, e de como era difícil trabalhar com os cantos dos jaós sem que eles se tornassem uma mera transcrição no palco: esteticamente até interessante, mas um pouco carente da vida de um pássaro. Ele me falou então que, se pararmos para escutar um canto de pássaro na vida cotidiana (seja na cidade ou em lugares com menos ação humana), eles nunca ocorrem isolados: há uma profusão de outros cantos e outros sons que participam daquele canto, porque afinal o pássaro não canta isolado de seu ambiente, mas é modificado continuamente por ele e também o modifica com seu canto.

De modo que trazer um canto de pássaro para um palco é uma ação um tanto inefetiva se ele aparece isolado de qualquer ambiente; por outro lado, fazê-lo coexistir com outros sons pode trazer de volta um pouco daquela vida. Isso pode ser visto, por exemplo, nos momentos de tutti em Yamanaka Cadenza, terceiro dos Sept Haïkaï (Sete Haicais) de Olivier Messiaen, em que há uma profusão de instrumentos, cada um fazendo uma linha diferente da dos outros, e que se assemelha a um pássaro também distinto. Como diz Francisco de Oliveira (2013, p. 61), Messiaen buscou, nessa peça,

\footnotetext{
${ }^{37}$ Dentre tais processos em artes cênicas, destaco a participação no Laboratório de Atuação (LAt!, de 2018 a 2019) do Departamento de Artes Cênicas da ECA-USP, sob condução de Alice K. Yagyu; e duas peças da Escola de Arte Dramática da USP (em 2015 e em 2017 a 2020), ambas sob direção de Cristiane Paoli Quito, em que participei como diretor musical e músico de cena.
} 
que os instrumentos em tutti soassem de forma a não terem seus sons aglutinados uns nos outros. Cantos de pássaros, assim, que coexistem mas que não se juntam em uma massa sonora homogênea ${ }^{38}$.

Mas os Sept Haïkaï de Messiaen foram escritos para um grupo com diversos instrumentistas. Como conseguir a profusão de sons do ambiente de um pássaro a partir apenas de uma instrumentista?

Uma alternativa seria trabalhar a partir de diferentes gestos sonoros, ou mesmo aglomerados gestuais, encadeando-os em um fluxo. Dessa forma, haveria um pequeno universo sonoro em que os jaós estariam imersos, tudo isso partindo da respiração que abriria a presença de Jessica no palco, deixando que o mirante aparecesse ${ }^{39}$. E pretendia também trabalhar os sons desse pequeno universo para que contivessem algo daquela mata da Chapada dos Guimarães.

Mas, como fazer isso, se nunca estive naquele lugar?

Não estava sozinho, naturalmente. Se, como nos diz Cavarero (2011), e como falei mais profundamente no capítulo 2, nossa voz é única, essa unicidade pode ser encarada como potência criativa: por ser "diferente de todas as outras vozes", como fala Calvino (1995), uma voz pode correr por linhas criativas diferentes de outra. E, continuando com Cavarero, essa unicidade das vozes é relacional: uma voz é única porque é percebida como tal pelas outras vozes. Assim, essa potência criativa de uma voz floresce na relação com outras vozes. Nunca estive na Chapada dos Guimarães, mas era pela voz de Jessica que aquele lugar ganhava vida no processo.

Mas no momento em que eu trabalhava nos manuscritos, eu estava sozinho, naturalmente. Um trabalho solitário, mas que de modo algum fala apenas a si mesmo; é muito mais como nos dizem Gilles Deleuze e Claire Parnet (1998, p. 14): essa solidão é extremamente povoada, e povoada de encontros. No caso deste processo, do encontro com Jessica, mas não simplesmente do meu mundo com o dela. Não um encontro de autores, uma autoria conjunta, porque

Ele, o Autor, constitui um ponto de origem, um sujeito de enunciação, do qual dependem todos os enunciados produzidos. Já as funções criadoras são usos do tipo rizoma, não árvore, que procedem por pontos de encontro e intersecções: não há sujeito, mas agenciamentos coletivos de enunciação, não há especificidades, mas populações, música-escritura-ciência-audiovisual, com suas substituições, seus ecos, suas interferências de trabalho. (...) não são encontros entre domínios, pois cada domínio já é feito, em si mesmo, de tais encontros. (DELEUZE; PARNET, 1998, p. 37-38)

${ }^{38}$ A associação das linhas dos tutti de Yamanaka Cadenza com cantos de pássaros, embora não esteja na dissertação de Oliveira (2013), foi abordada por ele em apresentação numa aula de Silvio Ferraz no Departamento de Música da ECA-USP, cerca de 2017.

${ }^{39}$ Ao imaginar tal fluxo, logo me vieram à mente diferentes peças que operam essa alternância de gestos sonoros, como a Sequenza III para voz solo de Luciano Berio ou algumas das Récitations de Georges Aperghis. 
Assim como um canto de pássaro perde sua vivacidade quando isolado de seu ambiente, porque ela precisa de outros cantos e outras vozes, também a composição precisa dos encontros, precisa da pluralidade das vozes. E essas vozes são únicas, não iguais: os campos de domínio de Jessica são diferentes dos meus - grosso modo, ela na performance e eu na composição. Que tipo de domínios?

Não os domínios hierarquizados da tradição da música erudita ocidental, compositor como origem da obra e performer como mero intermediário ou atravessador (cook, 2006, p. 7): essas hierarquias não nos interessam como prática. Falo dos domínios de trabalho, simplesmente; o que cada um estuda e no que se aprofunda no seu cotidiano. Dizer que a composição precisa dos encontros é dizer que ela é apenas mais uma dentro do microcosmos de práticas que compreendem um processo criativo musical. (Sobre que prática seria a composição no meu caso, essa dissertação relata isso.)

Se para dar vida ao canto do jaó era preciso também um ambiente, uma mata cheia de outros cantos e sons, era com Jessica que esses sons podiam surgir. Havia vários gestos sonoros que havíamos discutido naquela primeira conversa, em 21 de março, e também num encontro menor em 2 de abril; alguns deles eram mais relacionados com o repertório que ela estudava na clarineta à época, e outros surgiram a partir do relato dela sobre a Chapada dos Guimarães. Como havia feito anotações e gravado aquela conversa, retomei aqueles gestos sonoros ${ }^{40}$ depois da conversa com Silvio Ferraz, em abril, anotando as imagens poéticas às quais alguns deles já haviam se relacionado nas conversas:

- som da respiração dentro da clarineta;

- multifônicos próximos em uma sequência lenta;

- sons de chaves em escalas rápidas no médio-grave, em pianíssimo;

- nota mi mais grave da clarineta (soa ré), longa e com dinâmica oscilante;

- trilo entre o segundo mi (primeira linha da pauta com clave de sol) e fá natural;

- frullato no médio-grave, como um urro de um dinossauro;

- glissando no agudo e no extremo agudo, também como urro de um dinossauro;

- além, é claro, do canto do jaó.

O dinossauro, citado no frullato e no glissando, era uma imagem que eu havia sugerido a Jessica através de uma pergunta na primeira conversa: como seria um dinossauro na clarineta? Depois de experimentar um pouco, ela montou uma sequência: um multifônico, depois notas agudas e curtas, e glissandi agudos e no extremo agudo. "Nada de tempo, coisas picadas e aleatórias, como alguém imprevisível. Coisas

40 Para quem não está familiarizado com os termos usados, uma breve explicação. Multifônico: quando um instrumento ou corda emite um som em que é possível distinguir dois ou mais sons internos. Sons de chaves: quando o som das chaves da clarineta, tocadas pelos dedos, é audível. Nota mi que soa ré: na partitura, as notas da clarineta são diferentes das que soam, por ela ser um instrumento transpositor. Trilo: alternância rápida entre duas notas. Frullato: som rugoso, obtido ou com a garganta ou com a língua (fazendo um ' $R$ ' rolado) enquanto se toca a clarineta. Glissando: quando uma nota "desliza" para outra, continuamente. 
estáticas e de repente ele surta, algo que você não espera a reação. O bicho, surtei, o esquizofrênico", como ela disse naquela conversa de 21 de março de 2019.

Havia, assim, oito gestos sonoros e algumas imagens poéticas para começar a criar esse pequeno universo dos jaós no mirante. Poderia encadeá-los de diferentes formas: por similaridade geral ou de parâmetros (como quantidade de ar requerida), por contraste, por região sonora... Mas esses sons não vinham sozinhos; de fato, chamo-os de gestos sonoros porque envolviam uma gestualidade corporal: quando Jessica os fez, nos encontros, havia uma postura e uma pequena movimentação corporal específica em vários deles; e mesmo os que não tinham isso (como o trilo, o frullato, o glissando) sugeriam também algum movimento.

E, afinal, no encontro de 11 de abril, em que experimentamos o manuscrito da figura 17, tanto Jessica como eu havíamos gostado do uso de movimentos corporais. Como unir tantos gestos sonoros com movimentações, e como anotar tudo isso de forma que Jessica pudesse memorizar o que estávamos criando?

\subsection{Movendo o ar}

nuvens e folhas

balançam e correm o vento

e o sol caminha

Os gestos daquele primeiro manuscrito aconteciam a partir de dois eixos principais: a posição da clarineta e a direção do corpo - de certa forma, um eixo vertical e outro horizontal. A partir deles, vimos que era possível delinear diversos movimentos. Mas havia um problema: tanto Jessica como eu desejávamos que houvesse uma partitura física, para facilitar tanto o estudo e desenvolvimento da performance como a própria composição, pois com uma partitura podíamos nos lembrar rapidamente do que havíamos feito, encontrado e combinado nos encontros e nos estudos individuais.

Uma partitura como ferramenta de estudo.

Mas desde aquele primeiro manuscrito (cf. figura 17), vimos também que aqueles dois eixos precisavam de uma notação direta e simples de entender, já que eram a base dos movimentos que ocorreriam por toda a peça. Assim, junto com Silvio Ferraz, na conversa já citada de abril de 2019, elaborei alguns símbolos para cada estado de cada eixo (de forma que os estados pudessem ser combinados livremente), além de uma notação específica para um glissando em que o som das chaves é o mais importante. Essas notações, além das que já haviam sido usadas no primeiro manuscrito, podem ser vistas na figura 18. 
cabeças de nota:

- ação física (anda, pára etc.)

○ inspiração (dentro da clarineta)

$\times$ expiração (dentro da clarineta)

$\Delta$ eólio (nota com som de ar)

- som ordinario (com nota)

$$
\begin{aligned}
& \text { gestos: } \\
& \bigotimes---\varnothing
\end{aligned}
$$

posição da clarineta:

$\$$ para baixo (ordinario)

$\triangle$ para frente (horizontal)

$\triangle$ paracima direção do corpo:

- para a esquerda

Q para a diagonal esquerda

$\Phi$ para a frente

$\varnothing$ para a diagonal direita

$\odot$ para a direita

\section{glissando com}

muito som

de chaves

Figura 18: Excerto da bula da última partitura de Mirante, com as notações usadas até o segundo manuscrito (exceto os símbolos para ação física e eólio, que vieram depois).

Com tal notação, eu tinha as ferramentas de escrita de que precisava. Mas trabalhar com movimentos corporais não é algo tão habitual para músicos, como já disse; e, se isso era verdade para mim, era também para Jessica. Não partíamos do nada: uma grande referência para nós era a peça Harlekin, composta por Karlheinz Stockhausen em 1975, em especial na montagem da clarinetista brasileira Paula Pires. Eu tinha assistido à montagem de Pires em 2016 no IA-Unesp ${ }^{41}$, e Jessica a assistiu em abril de 2019 no I Encontro de Clarinetistas de Mato Grosso, em Cuiabá. Nessa peça, o/a clarinetista realiza diversos movimentos enquanto toca a clarineta, numa dança pelo espaço: ora os movimentos e os sons caminham juntos, ora se distinguem em planos distintos.

Esse contraponto dos planos - grosso modo, sons e movimentos - nos interessava bastante. Assim como um contraponto de vozes pode tornar uma textura sonora mais rica, também um contraponto de planos poderia ampliar a profundidade da performance. Um exemplo simples de contraponto dos planos: fazer algumas vezes um glissando do grave ao agudo, e junto com ele levantar a clarineta - uma associação, uma homofonia de som e movimento. Depois de algumas vezes dessa forma, fazer o glissando mas manter a clarineta para baixo - a homofonia é quebrada, som e movimento se distinguem. Com isso, faríamos surgir imagens diferentes a cada momento.

Mas a dificuldade com os movimentos ainda era algo a considerar. Como memorizálos? Como encadeá-los de forma fluida? Como tocar a clarineta em posições nada habituais? Embora os símbolos da notação pudessem ser combinados livremente, os movimentos tinham que se associar às técnicas da clarineta de forma minimamente ergonômica — ou seja, permitindo um tocar fluido. E, para facilitar a memorização, deveríamos encontrar um fluxo que passasse por esses movimentos.

Esse fluxo, na verdade, tinha a ver também com o que de fato queríamos com esses movimentos. Não era mover o corpo simplesmente por mover, para adornar os sons. $\mathrm{O}$

${ }^{41}$ Há um vídeo dessa montagem de 2016, de Paula Pires com a Harlekin de K. Stockhausen, disponível em https: //youtu. be/Y1myhhgBVQA (acesso em 4 nov. 2020). 
que queríamos era, como já disse, fazer surgir um mirante. Nesse ponto do processo, em abril de 2019, me lembrei de uma prática de que havia participado, no início daquele ano:

Naquela prática no Laboratório de Atuação ${ }^{42}$ (LAt!), conduzidos por Alice K., eu e outras pessoas traçamos linhas retas no chão, com o comprimento igual à nossa altura, e então tentamos percorrer cada um a sua linha em exatos cinco minutos, sem consultar o relógio. Depois, percorremos a linha de volta, também em cinco minutos; mas dessa vez, o que fazíamos depois dessa travessia era livre, partindo sempre dos impulsos do corpo. Esse exercício simples, andar numa linha, foi capaz de nos levar a uma improvisação que durou vários minutos, com giros, pêndulos, saltos pelo espaço... tudo a partir de uma travessia lenta rumo ao vazio.

Caminhar. Passo a passo, o cotidiano silencia, os ombros silenciam, os olhos focam. Respirar. Passo a passo, entrar no vazio que precede o mirante. Caminhar, respirar, passo. Pés na terra, olhos no horizonte. Abrir o céu. Chamar o mirante.

Compus a sequência inicial (até o começo do terceiro sistema) do segundo manuscrito, disponível na figura 19, a partir dessa travessia ao vazio. Uma caminhada em linha reta, com algumas respirações na clarineta, para sair do cotidiano e chegar no mirante. Para isso, naquele momento, desejava uma escrita que fosse fluida, rápida, quase como a escrita-desenho da respiração do capítulo 2; assim, usei uma folha branca, sem pautas, e compus como se escrevesse um poema: uma escrita que anotasse o tempo, por pontos e espaços vazios - algo como os experimentos de escrita de John Cage em seu livro Silence (1961) —; uma composição em que as indicações gestuais e as imagens poéticas caminhassem juntas, em igual importância.

A princípio, essa forma de escrita me permitiu compor de forma mais fluida, passando pelas imagens poéticas através de um fluxo temporal; porém, tão logo quis anotar os movimentos corporais e mesmo os sons, percebi que essa forma não dava conta desses planos sozinha. Não era o caso de abandoná-la, já que ela tinha potências próprias; mas, da mesma forma, não havia necessidade de evitar a notação tradicional quando seu uso fosse a maneira mais simples de trabalhar. No fim das contas, a questão era encarar a partitura como ferramenta ${ }^{43}$, não como obra. Se uma forma de notação é melhor em determinado momento do processo ou da peça, podemos mudar para ela - e por "melhor" me refiro a uma maior adequação às questões de cada momento do trabalho.

Foi assim que, na primeira página desse segundo manuscrito (cf. figura 19), mantive a notação das pausas com pontos e espaços vazios sempre que me parecia mais simples

42 Participei do LAt! por um ano, de agosto de 2018 a agosto de 2019. Tal laboratório ocorre no Departamento de Artes Cênicas da ECA-USP, sob condução da Profa. Dra. Alice K. Yagyu.

${ }^{43}$ Encarar a partitura - ou qualquer outra técnica - como ferramenta foi algo que aprendi com Bruna Mayer Costa e Alexandre D'Elboux Filho, no processo discutido na seção 2.7 e em outros. 


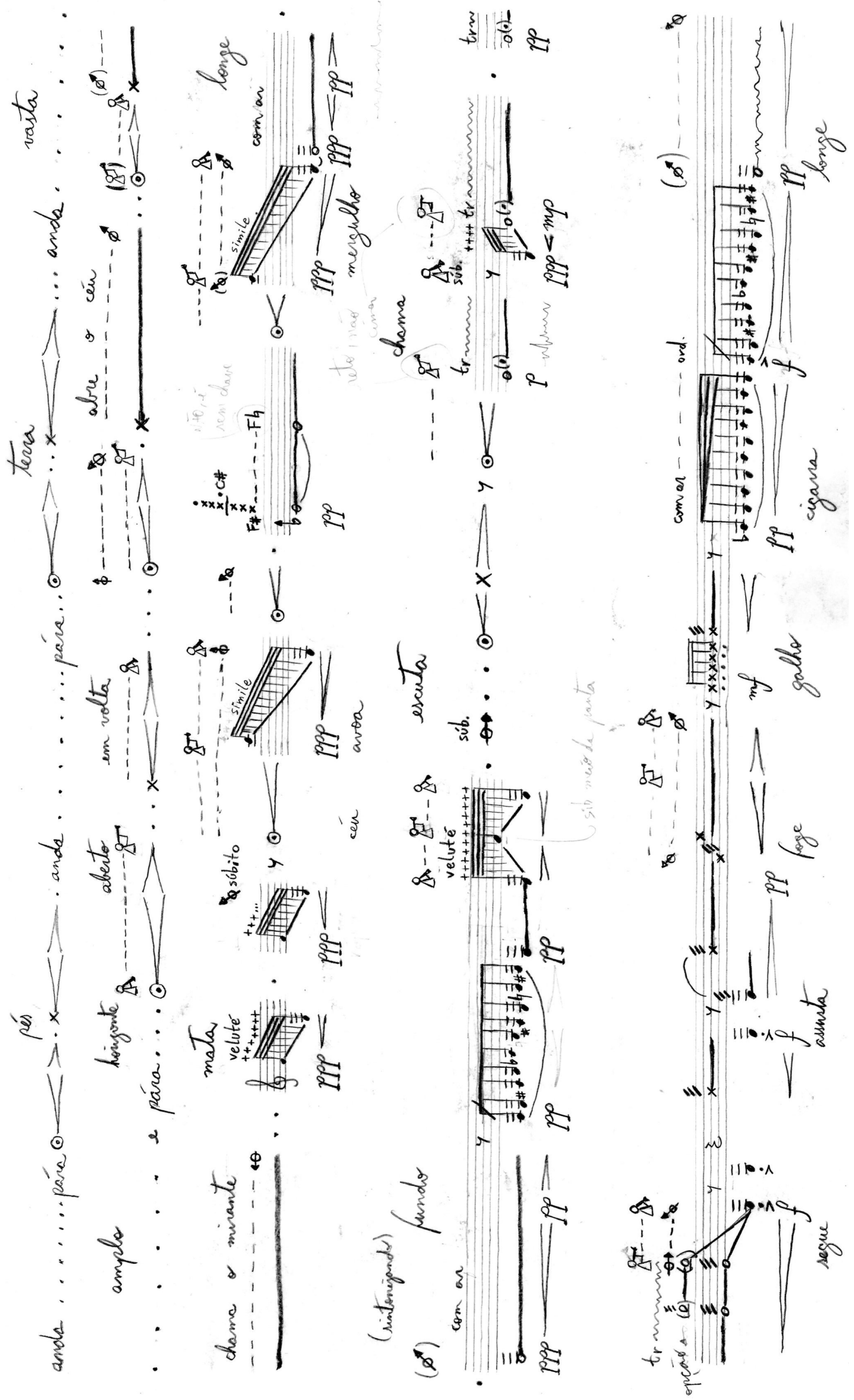

Figura 19: Primeira página do segundo manuscrito da peça Mirante, escrito ao longo dos meses de abril e maio de 2019. Para a primeira página, cf. figura 22. 
de entender. E no gesto da respiração na clarineta, usei uma notação um pouco diferente da do primeiro manuscrito, com crescendo e decrescendo para cada gesto, sem pauta ou linha.

Além da sequência inicial (travessia), compus o que seria uma espécie de primeira seção (embora não haja divisões muito claras na peça): na figura 19, do início até a pausa de semínima no último sistema. Uma diferença grande em relação ao primeiro manuscrito (cf. figura 17): em vez de inserir o jaó logo depois do chamamento do mirante, deixei esse trecho sem qualquer canto de jaó, para que ele aparecesse mais para frente. Isso porque, como Silvio Ferraz me chamou à atenção na conversa citada de abril, toda a travessia inicial da peça não emprega o som ordinario da clarineta, mas sim sons de respiração; já o canto do jaó é feito com um som bem mais tradicionalmente reconhecido de clarineta. Assim, colocá-lo logo depois das respirações dificultaria qualquer escuta de um pássaro, porque a identificação do som como "clarineta" seria muito mais forte.

A partir disso, também, busquei uma sequência de gestos sonoros que gradualmente mostrasse o som ordinario da clarineta: respirações, sons de chaves, multifônicos, mi grave em pianíssimo, notas rápidas e graves em pianíssimo, e trilo com dinâmica média. Não era exatamente uma interpolação contínua entre som de sopro e de nota: intercalei os gestos, a partir dos movimentos de cada momento e gerando contrastes, justaposições de sonoridades distintas - como quando um multifônico sucede sons de chaves. Pequenos cortes, em vez de uma transformação gradual, para que a força das transições de estado não se esvaísse; para que, como Silvio Ferraz diz em um artigo, houvesse momentos súbitos em que as relações todas se abrem. (FERRAZ, 2014, p. 25-26)

Já havia trabalhado essa demora em mostrar o som tradicional de um instrumento no processo citado com Lucas Raulino, da peça Luthieria: apenas nos momentos finais da peça aparece de fato um som "violinístico". Isso gera uma curiosidade no público, um plano secundário de percepção em que surge a dúvida: é mesmo esse instrumento, ou há algum efeito, alguma modificação das cordas ou coisa parecida? Com isso, a multiplicidade sonora e gestual de um instrumento - e da/do instrumentista! — é trazida ao primeiro plano. Ao mesmo tempo, se em Luthieria essa "revelação" do instrumento tinha a ver com o fluxo imagético da peça, no processo com Jessica isso se relacionava mais com a possibilidade de enxergar um pássaro no palco: através da performer, enxergar um bicho vivo. (MATTOS NETO; RAULINO, 2019, p. 6-7)

Mas é preciso dizer que tal transformação do instrumento é operada, no fim das contas, não apenas por quem compõe mas principalmente por quem toca. Assim como Raulino trabalhou seu som para que o violino não soasse violinístico, também Jessica me mostrou que a gradação entre sons de sopro e de nota podia ser ainda mais sutil. No encontro de 10 de maio, em que levei o segundo manuscrito (fotocopiado e ampliado para A3), foi ela que deu vida e ampliou a imagem poética do mi grave 
(cf. terceiro e quarto sistema, figura 19, em especial a anotação "sintonizando"): em vez de apenas pianíssimo, ela criou outro som, com muito ar e com uma irregularidade do sopro. E fez isso justamente por identificar que era a primeira vez em que aparecia uma nota definida: era preciso "sujá-la" com o ar, já que vínhamos do som do ar antes.

Esse mi grave com o ar entrecortado, para ela, era ao mesmo tempo como o vento e como sintonizar uma rádio pequena a quilômetros de qualquer cidade. Um ar que passa: "estou pensando no vento, esse vento que você está tentando desenhar, e aí começando a entrar um instrumento ali dentro". Um som vacilante, instável: "essa instabilidade do mirante mesmo, sabe aquelas rádios no meio do mato (...) Cidade sai, cidade fica... Porque está muito perto, mas está muito longe também", como ela disse naquele encontro de 10 de maio, cujo registro está disponível na figura 20 e em https : //youtu. be/Y7oAGSA705c e https: //youtu . be/agw2906a-iA (acesso em 7 nov. 2020). A própria notação do ar entrecortado, uma linha grossa irregular ${ }^{44}$, foi criada também por ela na ocasião, além da junção desse sopro irregular com o trilo que vem um pouco depois.

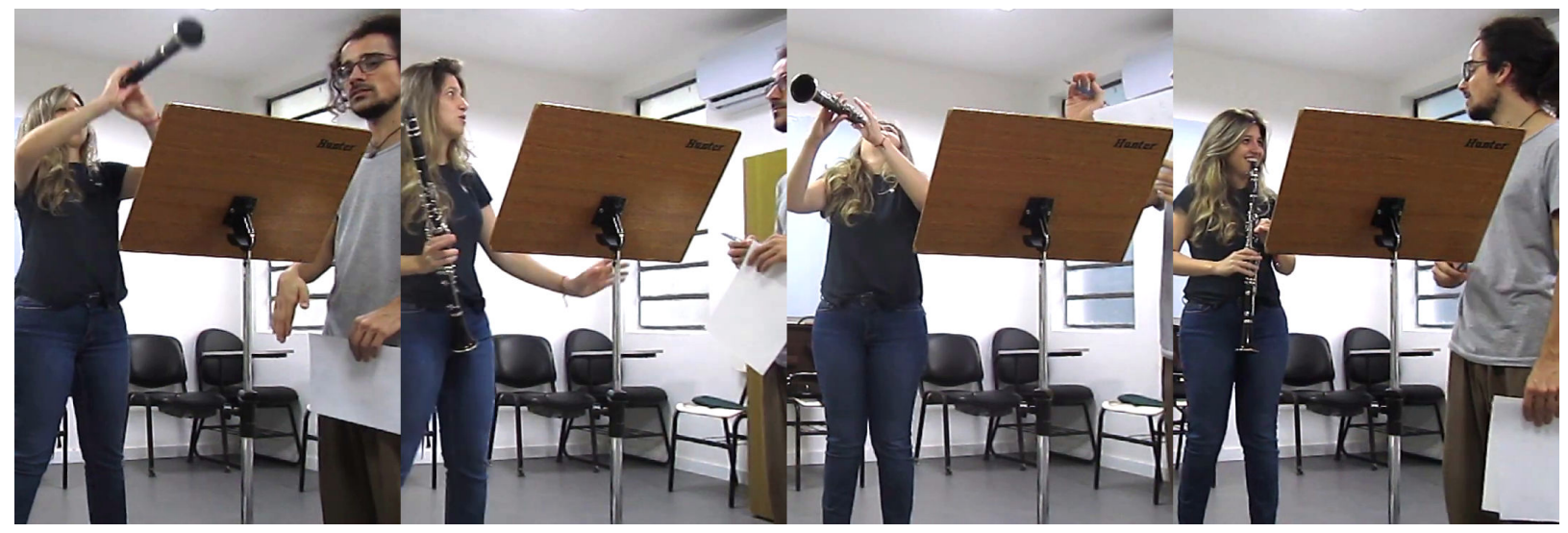

Figura 20: Dois registros do encontro de 10 de maio, em quatro momentos, em que lemos o segundo manuscrito (cf. figura 19). Disponível em https ://youtu. be/Y7oAGSA705c e https://youtu. be /agw2906a-iA (acesso em 7 nov. 2020).

Além dessas e de outras mudanças, ela criou um gesto a partir do que eu tinha escrito na ocasião, que usei num trecho posterior: um frullato forte que, ao decrescer, perde o som da nota e vira som de ar, de expiração, mas ainda com o frullato: uma junção desses dois gestos sonoros. E, ao passarmos pelas mudanças da direção do corpo, vimos que era mais interessante que elas ocorressem sem mover os pés, porque assim o gesto seria mais assertivo e limpo. Os gestos curtos ou súbitos, por sua vez, pediam uma ação próxima à de um pássaro pequeno: rápida, com vivacidade. E, já naquele encontro de 10 de maio, ela inseriu essa vivacidade em vários trechos.

A partir do encontro que tivemos no dia 13 de maio - cujo registro está disponível na figura 21 e em https : / / youtu. be/hRGy_IJ_TEc (acesso em 10 nov. 2020), encontro esse em que estudamos a performance para apresentá-la no Laboratório de

${ }^{44}$ Essa notação pode ser vista no final da página da figura 19. Cabe ainda dizer que tal encontro ocorreu em uma sala de estudos do Depto. de Música da ECA-USP. 
Interpretação e Criação Contemporânea ${ }^{45}$ - comecei a editoração digital da partitura, para facilitar as mudanças eventuais do processo, além do próprio estudo. Mas não abandonei o manuscrito: o trabalho composicional (no caso, escrever a sequência de gestos em fluxo) seguiu à mão, a partir do que íamos descobrindo e criando nos encontros. A segunda página do segundo manuscrito, disponível na figura 22 , foi escrita em partes: até metade do segundo sistema (fim do multifônico), e depois até o final da peça.

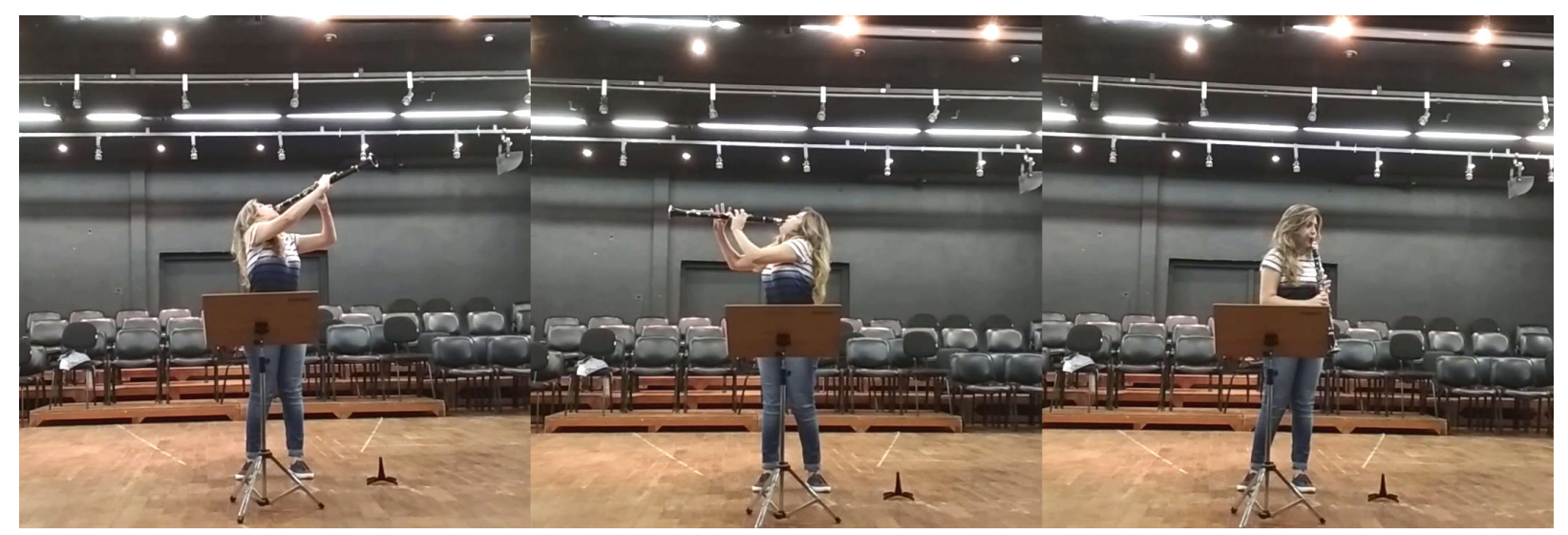

Figura 21: Trecho do encontro do dia 13 de maio, no Auditório Olivier Toni do Depto. de Música da ECA-USP. Disponível em https://youtu.be/hRGy_IJ_TEc (acesso em 10 nov. 2020).

Se eu já havia começado a fazer a versão digital da partitura, por que compor à mão?

escrever com a mão

a formiga que corre solta

pelo papel

Para mim, a escrita à mão, principalmente no caso da partitura, tem algo de simplicidade que ajuda a manter aquele vazio potente de que já falei, no qual algo novo pode surgir. Se preciso de uma linha longa e irregular, traço-a com o lápis; um glissando que atravessa outro gesto, simples. Compor diretamente em um software editor de partitura, por outro lado, é lidar com interrupções constantes (encontrar o símbolo de que preciso, desenhar os que não existem, ajustar sua posição e tamanho etc.). Além do mais, gosto de escrever e compor à mão (como talvez fique evidente pelo capítulo 2), e isso influencia minha abertura interna ao processo criativo.

Ao mesmo tempo, o momento de editorar digitalmente uma partitura manuscrita é bem interessante: é quando posso revisar e refinar a notação, estabelecendo padrões que ajudem na leitura. Além do mais, para Jessica foi muito mais fácil estudar com as versões digitais, como ela me disse nos encontros. A versão digital seria, assim, uma partitura de estudo - tanto para Jessica como para mim, porque fazia as revisões nessa versão, a partir do que descobríamos e trabalhávamos nos encontros.

${ }^{45}$ Tal laboratório ocorre no Depto. de Música da ECA-USP, sob coordenação dos Profs. Drs. Silvio Ferraz, Luis Afonso Montanha, Eliane Tokeshi, Ricardo Bologna e Fábio Cintra. 


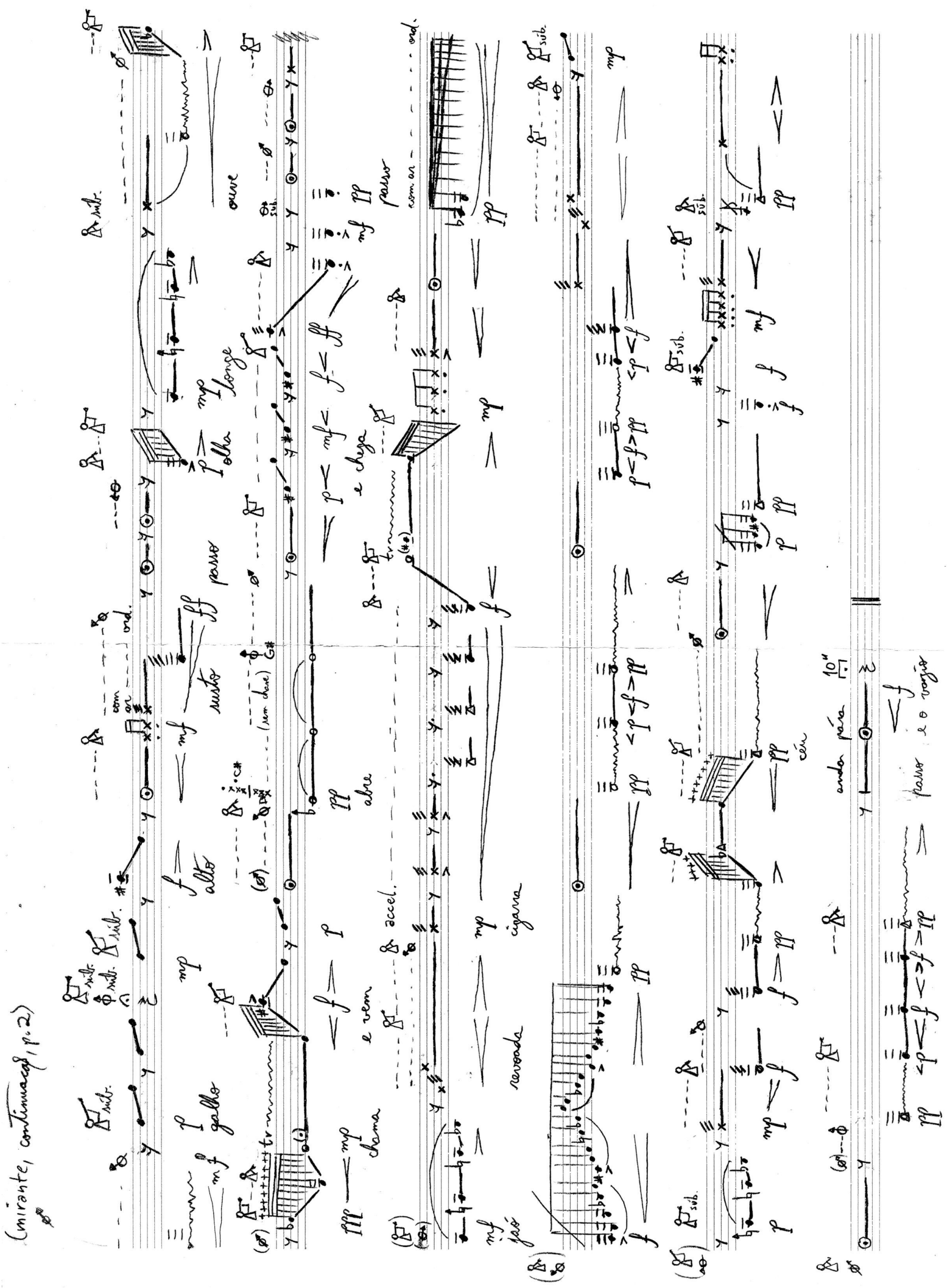

Figura 22: Segunda página do segundo manuscrito da peça Mirante, escrita ao longo dos meses de maio e junho de 2019. Para a primeira página, cf. figura 19. 
Mas há um problema. Como já disse, o segundo manuscrito (cf. figuras 19 e 22) foi escrito em partes; e foi assim também com a editoração digital. Essas diferentes versões da partitura, principalmente da digital, foram entregues nos encontros de maio e junho, em que estudamos juntos os trechos novos e os já lidos. E aí está a dificuldade: cada novo trecho, cada nova versão gera mudanças visuais na partitura que atrapalham a memorização e o estudo, como Jessica comenta na seção 3.1. Por mais que Jessica sempre aceitasse mudanças (e inclusive trouxesse várias), elas eram cada vez mais custosas para a continuidade do fluxo da performance.

E, além disso, tal fluxo não consistiria apenas de movimentos e sons tecnicamente bem-feitos. Mesmo com a riqueza de gestos que havíamos criado, ainda faltava algo para trazer o mirante.

\subsection{Escutar a mata}

$$
\begin{aligned}
& \text { pisar-respiro } \\
& \text { abrir pescoços todos } \\
& \text { aqui-agora } \\
& \text { água escorre } \\
& \text { por morros e vales } \\
& \text { da minha pele }
\end{aligned}
$$

Quando participei como músico de cena da peça .Fatzer: um estudo ${ }^{46}$, havia um pequeno monólogo, feito por uma atriz, contando a situação do povo em miséria durante a $1^{a}$ Guerra Mundial. Lembro-me de que, em várias das récitas, conseguia ver tudo o que a atriz dizia: as roupas em trapos, a fome que corroía o corpo, o carvão que acabava antes mesmo do inverno chegar. Mas, em algumas récitas, tive mesmo a sensação de estar em meio à neve, em 1917, na porta de uma cidade abandonada. Não imaginava apenas, eu estava lá. Eu, as outras pessoas do público e da peça, e a atriz.

Em outra ocasião, em 2017, assisti à montagem do Quatuor pour la fin du temps (Quarteto para o fim do tempo) de Olivier Messiaen pelo grupo QuartaD ${ }^{47}$. No início do terceiro movimento, Abîme des oiseaux (Abismo dos pássaros), há um crescendo na clarineta solo vindo do silêncio. Montanha, o clarinetista, fez esse trecho com um olhar que ia buscar a quilômetros dali o som através da parede lateral de vidro da sala; e, de fato, o som da clarineta surgiu antes que pudesse percebê-lo, brotou sorrateiro das paredes para, aos poucos, ganhar corpo sonoro.

${ }^{46}$ Baseada na peça de Bertolt Brech O declínio do egoísta Johann Fatzer, ela foi montada pela Turma 65 da Escola de Arte Dramática da USP, sob direção de Cristiane Paoli Quito, em 2015.

47 Formado por Luís Afonso Montanha (clarineta), Luiz Amato (violino), Raiff Dantas Barreto (violoncelo) e Paulo Braga (piano). 
Como é isso? Esse fenômeno de ser capturado por uma voz, por um corpo, por uma performance, essa coisa de se ver atirado em um fluxo poético que rompe paredes e relógios?

A raiz do problema consiste em saber se a cada momento, no ato de escrever ou de atuar, existe uma faísca, uma pequena centelha que se acende e dá intensidade a esse momento comprimido, destilado. Porque a compressão e a condensação não bastam. Mesmo se fazendo cortes numa peça longa demais ou muito prolixa, ela pode continuar sendo chata. O que importa é a centelha, que nessa peça surge muito raramente. É uma prova de que a forma teatral é terrivelmente frágil e exigente, pois essa centelhazinha de vida tem que estar presente a todo instante. (BROOK, 2000, p. 10)

Simples, belo, poético esse trecho do diretor de teatro Peter Brook. Mas, como alcançar essa centelha?

Ao compor (trabalhar no papel, no caso), tentei manter essa chama acesa de diferentes formas. Já disse algumas delas: organizar o ambiente de trabalho; prestar atenção à minha respiração e ao meu corpo; experimentar com o corpo o que compunha (tanto quanto possível); incluir na partitura as imagens poéticas de cada trecho ou gesto; usar uma notação que me fosse simples de escrever, se possível próxima à escrita de um poema. Essa última, em especial, implicou diferenciar a partitura de composição (com escrita mais livre, manuscrita) da partitura de estudo (com notação refinada, digital).

Além dessas formas, sempre que voltava ao trabalho - fosse depois de dias/semanas, ou horas/minutos - , retomava o próprio fluxo da peça, solfejando a sequência de gestos com o corpo e a respiração. Embora isso não trouxesse nenhuma garantia de qualidade ao trabalho (até porque isso dificilmente existe), ao menos reacendia aquela centelha de vida dentro de mim, me levava novamente para perto do mirante. Ou, para falar com o compositor Salvatore Sciarrino, fazer isso era deixar crescer em mim o silêncio, adensar o vazio. (SCIARRINO, 2020)

Mas na performance isso é um pouco mais complicado.

Há o público, e todas as expectativas de uma situação de performance; há a peça que, embora nesse caso não tenha o peso de uma obra tradicional, ainda assim estabelece mais outras expectativas do que pode ou não acontecer; há as dificuldades técnicas - do instrumento, do espaço, daquele dia específico, da peça. E, no caso da peça que criávamos, há ainda os movimentos e as imagens poéticas. Como lidar com tudo isso?

Da minha parte, busquei um fluxo e uma notação que se abrissem ao ritmo específico de cada performance. Por exemplo, a notação das durações é sempre relativa e aproximada: uma cabeça de nota (que determina o tipo de ação; cf. figura 18) é prolongada por uma linha grossa (reta ou torcida) que mostra sua duração relativa. Não há precisão no quanto dura cada linha, de modo que os gestos e movimentos 
podem mudar de acordo com quem toca, em que dia, em que estado de espírito etc ${ }^{48}$. E a caminhada inicial, que me serviu na composição para me distanciar do cotidiano e chegar no mirante, tinha esse mesmo papel na performance: abrandar a ansiedade e a expectativa e pisar com os pés.

Trabalhamos a caminhada em alguns encontros específicos. Em um deles, no dia 16 de junho de 2019, propus dois exercícios (depois de alongamentos e respirações). No primeiro (repetido algumas vezes), me posicionei atrás de Jessica, marcando com minhas mãos, estáticas, a posição inicial dos seus ombros. Então pedi que ela desse alguns passos para frente, parasse, e voltasse de costas, tentando voltar para o mesmo ponto. Com tal exercício, que aprendi no Laboratório de Atuação (LAt!) com Alice K. (citado anteriormente), é possível tomar consciência do quanto oscilamos para os lados quando andamos no cotidiano; e, com essa consciência, podemos buscar uma caminhada em que nosso eixo oscila menos, um movimento mais limpo. Há um registro desse exercício (sem que eu estivesse marcando a posição inicial, já que estava gravando) na figura 23 e em https : //youtu . be/rcsoDSP8k8Q (acesso em 10 nov. 2020).

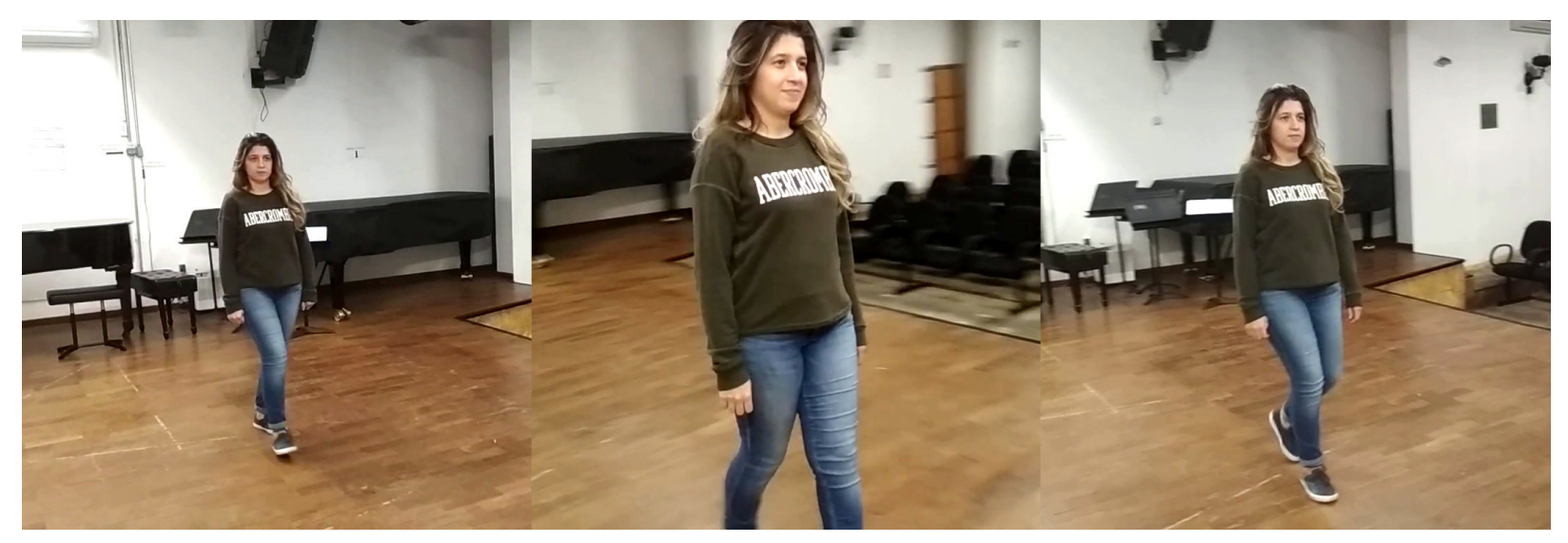

Figura 23: Três momentos do exercício da caminhada, na sequência: partir de um ponto fixo, andar alguns passos, e andar para trás chegando no mesmo ponto. Disponível em https://youtu . be /rcsoDSP8k8Q (acesso em 10 nov. 2020).

No segundo exercício, propus aquela travessia ao vazio ${ }^{49}$ de que falei antes, também experimentada no LAt! com Alice K. Porém, havia alguns problemas: não dispúnhamos de giz, fita ou outra coisa que pudesse marcar uma linha provisória no chão; e o espaço em que estávamos (o palco do Auditório do Depto. de Música da ECA-USP), embora fosse amplo, tinha diversas cadeiras, instrumentos e equipamentos à vista (como pode ser visto nas figuras 23 e 24), o que gerava distrações visuais. De modo que usamos

48 Já havia usado notação semelhante nas peças Beira-mar, para tuba e harpa (citada no capítulo 2) e Luthieria, para violino (MATTOS NETO; RAULINO, 2019), embora, nessa última, a duração fosse anotada pela distância entre as cabeças de nota e não por linhas. As pausas, embora sejam marcadas com figuras rítmicas (pausa de semínima e de colcheia), anotam apenas pausas longas e breves.

49 Relembrando rapidamente o exercício: alguém deve atravessar uma linha reta tentando fazê-lo num tempo determinado (no caso, cinco minutos), marcado por outra pessoa, que não diz quando o tempo acaba. Ao final, é dito quanto tempo realmente foi gasto, e a travessia de volta é feita, novamente em cinco minutos, dessa vez dando liberdade de movimentos ao final. Como a linha é relativamente curta, a travessia é lenta. 
um dos praticáveis ${ }^{50}$ como "linha", e o colocamos direcionado para a parede mais lisa e sem distrações do palco. E, depois do exercício, Jessica fez a sequência inicial da peça, cujo registro está na figura 24 e em https: //youtu . be/4GFVFPrtzFM (acesso em 10 nov. 2020).
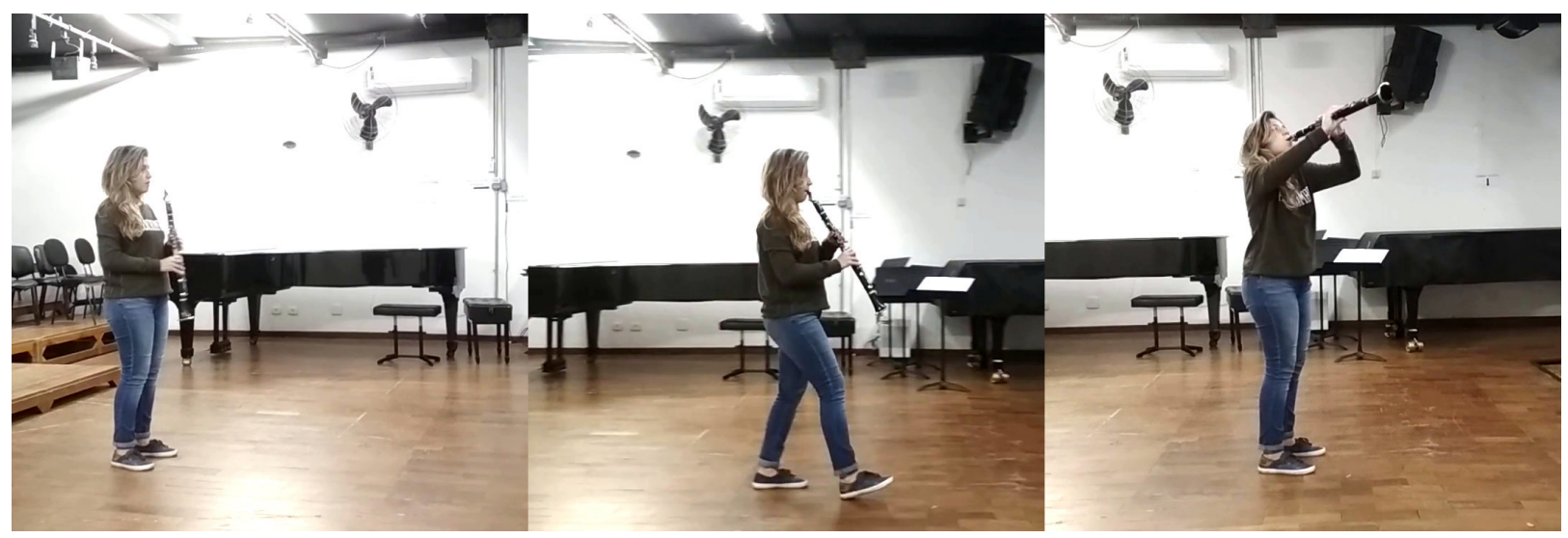

Figura 24: Três momentos depois do exercício da travessia, com a sequência inicial de Mirante. Disponível em https: //youtu. be/4GFVFPrtzFM (acesso em 10 nov. 2020).

Além desses dois registros, há também um registro desse dia, anterior a essas práticas da caminhada, na figura 25 e em https://youtu.be/1-9ImnY_1_w e https://youtu . be/gFKhBuxf-rY (acesso em 10 nov. 2020). Neles, é possível observar como estava a peça até aquele momento.

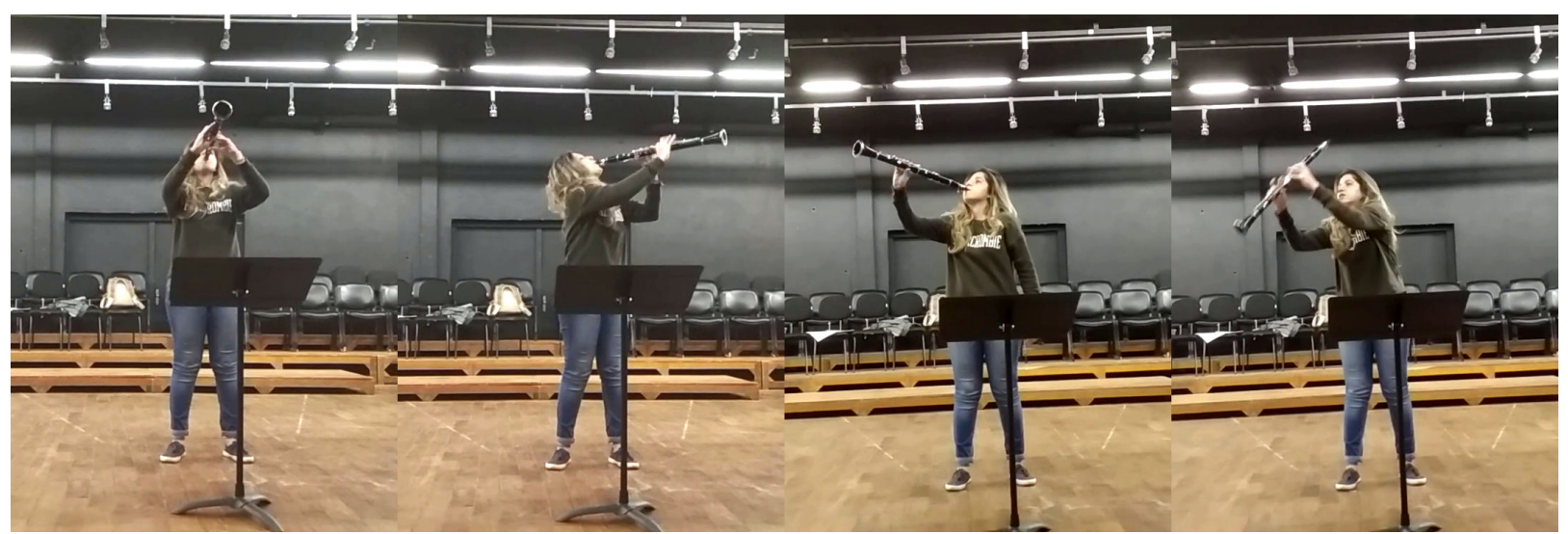

Figura 25: Duas passagens da primeira parte de Mirante, anteriores às figuras 23 e 24. Disponível em https://youtu.be/1-9ImnY_1_w e https://youtu.be/gFKhBuxf-rY (acesso em 10 nov. 2020).

Caminhar em cena não é simples. O público nos observa em tudo que fazemos; e, embora seja interessante observar a diferença única do andar de cada pessoa, essa diferença pode, em certo grau, atrapalhar o esvaziamento do espaço. Além disso, a busca por um caminhar mais centrado pode dar maior liberdade aos movimentos e rapidez às reações. (OIDA, 2007, p. 22-23, 47-50) Melhor dizendo, caminhar em cena é simples; mas essa simplicidade não é fácil.

Estamos falando do mais simples dos movimentos — caminhar e mesmo assim existe uma diferença fundamental entre aquilo que

${ }^{50}$ Um praticável, no caso, era uma base comprida de madeira em que se apoiavam as cadeiras destinadas às aulas de canto coral do departamento. 
produz intensidade de vida e o que é mero lugar-comum. (BROoK, 2000, p. 13)

Trabalhar a caminhada inicial em profundidade ajudou Jessica a alcançar tanto uma fluidez dos movimentos (cf. registro da figura 24) como uma abertura às imagens poéticas que podiam surgir ao longo da performance. Além disso, embora aquele trecho fosse principalmente para ela, não para o público, essa caminhada acabou se tornando também uma preparação da percepção - para usar ideias de Sciarrino (2020) - , acalmando a escuta e criando um outro espaço, um estado de graça, a contemplação do vazio ${ }^{51}$.

Em outro momento, pudemos mostrar o que já tínhamos da peça para Silvio Ferraz e Luís Afonso Montanha (professor de clarineta e orientador de Jessica). Na ocasião, eles jogaram luz sobre diversas passagens e questões da peça. Por exemplo, Ferraz sugeriu que uma sequência de sons de chaves e respirações, no começo da peça, fosse improvisada em vez de anotada. Montanha ajudou a acentuar as particularidades de cada sonoridade (multifônicos, sons de chaves, notas aleatórias com muito ar, ar entrecortado etc.). Ambos ajudaram em questões de postura e de continuidade dos gestos e movimentos. E, num trecho específico com um glissando até o extremo agudo, decidimos inserir um giro para trás $\left(180^{\circ}\right)$, fazendo o som preencher o espaço. Essas mudanças ajudaram a manter o fluxo da peça.

Quando falo de manter o fluxo, me refiro de certa forma àquela centelha de que Brook (2000, p. 10) nos fala. Por outro lado, tomo também as ideias de Silvio Ferraz sobre uma música que seja o correr de um fluxo de energia. Esse fluxo modula (e é modulado por) quem é atravessado por ele; uma música que respira como uma coisa viva:

$$
\begin{aligned}
& \text { uma música que é como o vento ou como o ar, é pensar a composição } \\
& \text { musical nos limites de ser apenas uma sequência de sons que } \\
& \text { respiram. Com isto proponho também uma escuta simples que é } \\
& \text { aquela de apenas respirar-se junto com a música. (...) Ou seja, respirar } \\
& \text { e fazer com que o ouvinte respire a todo tempo apenas o fluxo do som, } \\
& \text { um lugar quase que de presente pleno (...). Corre tudo assim como } \\
& \text { o rio, sem futuro e a-histórico. Uma forma de escuta que talvez se } \\
& \text { possa comparar com a sensação de olhar o mar, ou olhar um bambuzal } \\
& \text { balançando ao vento, ou ainda ouvir o cântico rangido dos balanços e } \\
& \text { gangorras de um parque de diversões. (FERRAZ, 2014, p. 23, 24) }
\end{aligned}
$$

Manter esse fluxo exige perceber se há momentos que não respiram, que perdem a vivacidade, perdem a centelha de vida. E compor assim exige, para mim, abrir a escuta à performance, às suas potências e aos momentos em que o meu trabalho bloqueia o respirar de quem performa, em vez de ajudá-lo. Exige também um desapego ao que escrevo, ao que proponho. E como desapegar de uma determinada sequência, mesmo depois de feitos o manuscrito e a versão digital? Como digo mais tarde, a um certo ponto do processo nos fixamos em apenas duas versões da partitura digital. Se por

${ }^{51}$ Uso aqui a expressão contemplação do vazio emprestada de Sciarrino (2020), embora para ele tal vazio seja mais o limite em que um som brota, um entre vazio e som. 
um lado isso vinha de uma necessidade - facilitar o estudo e manter as anotações já feitas -, também implicava algum apego às sequências de gestos já trabalhadas, nos encontros e na notação.

Mas ainda faltava trabalhar uma dimensão da peça em que eu havia pensado durante a escrita: a distância de cada imagem poética. Ao longo do processo, surgiu a ideia da peça acontecer não apenas no mirante o tempo todo, mas também dentro da mata; e, nesse caso, as distâncias seriam bem menores, o horizonte se aproxima, de certa forma. Em uma anotação do dia 22 de maio, elenquei duas possibilidades: eventos percebidos como longos serem próximos (e curtos, distantes); ou então o lugar do foco determinar a distância. Se um evento exigia focar no instrumento (pela digitação, por exemplo), seria próximo; se o foco era a respiração, o evento seria distante. Duas imagens: galho (braços e mãos, próximo) e tronco (sopro, distante).

$$
\begin{aligned}
& \text { anoitece } \\
& \text { o tronco e os galhos } \\
& \text { jogam cabra-cega }
\end{aligned}
$$

Mas não sou clarinetista, nem instrumentista de sopro. Jessica me explicou que, para ela, tudo é sempre respiração quando ela toca, mesmo que haja uma digitação complexa. $\mathrm{O}$ foco da atenção não oscila tanto como pensei entre sopro e braços. Pensamos, então, que a clarineta para cima poderia trazer a proximidade, e para a frente, a distância; e foi com essa definição, por assim dizer, que concluí o manuscrito da figura 22 e acrescentei imagens em outros momentos.

Dois momentos ainda do processo, antes da esperada estreia:

Em um outro encontro, à noite, pedi a Jessica para improvisar os gestos da peça na frente do Depto. de Música da ECA-USP. (Para quem não conhece a ECA e o campus onde ela está, uma breve descrição: muitas árvores, vários pássaros, especialmente quero-queros, e uma boa distância entre os prédios.) O improviso tinha uma indicação: ela deveria reagir aos sons do ambiente, especialmente os de pássaros. A reação envolvia girar rapidamente o corpo (apontando o osso esterno, meio do peito) para a direção do som, e tocar algum dos gestos, mudando a posição da clarineta se fosse o caso: ou seja, a reação era uma brincadeira com os parâmetros dos movimentos. Com esse improviso, queria trazer a surpresa como o motor do movimento; e Jessica interagiu várias vezes com pássaros, com quero-queros que cantavam (gritavam) longe, que revoaram sobre nós. E mesmo um avião fez parte: em alguns momentos, o ouvimos passar, e ela reagiu a esse som, distante, grave, profundo, como se viesse também de um bicho. Um avião, pássaro imenso. Assustar-se com um bicho, maravilhar-se com outro, admirar uma revoada de pássaros e segui-la com os olhos e o corpo, na esperança de levantar voo.

No dia 21 de junho, a três dias da estreia, nos encontramos novamente, dessa vez para trabalhar a sequência final da peça. Tanto Jessica como eu preferíamos que a 
partitura participasse o mínimo possível da performance; assim, focamos em delinear os gestos, marcar suas posições e memorizar a sequência final, encadeando-a com tudo que já havíamos trabalhado. Começamos o encontro um tanto desesperados pela proximidade da apresentação, mas no final vimos que era possível.

E então chegou o dia da estreia.

\title{
3.6 Chamar o mirante
}

\author{
soprar o ar frio \\ do palco vasto à espera \\ acender o sol
}

Estreia. Nascimento em meio a um processo de meses. Trazer à superfície tudo o que vale e ajuda, e imergir o que não pôde ter espaço, submerso para talvez outro momento. Assumir o que fizemos como pronto hoje, uma fotografia do processo. Assumir que continuaremos, que tudo sempre se move e a foto é só uma foto. Mas fotografar é uma arte.

A sequência final de Mirante foi trabalhada na última semana antes da apresentação; embora não lidasse com gestos e movimentos novos (exceto talvez por um gesto simples do final), a sequência tinha alguns pontos difíceis de memorizar que, como disse, trabalhamos no dia 21 de junho.

Falo de trechos e sequências, e conto da versão digital da peça, mas como ela é? Nas figuras 26 e 27, podem ser vistas as duas páginas da partitura que usamos até a estreia; mas ela não contém tudo o que trabalhamos. Improvisação com chaves no início (segunda metade do segundo sistema), giro do corpo para trás no glissando ao extremo agudo (meio do sexto sistema), além de outras mudanças que fizemos em ensaio. Por que não estão na partitura?

Como disse antes, trabalhar com diferentes versões da peça, ao longo do seu desenvolvimento, gerava mudanças visuais na partitura que atrapalhavam a memorização e o estudo. Ao ponto que Jessica usou, para a estreia, duas versões distintas da partitura digital (uma até o fim do sexto sistema, outra em diante), para manter suas anotações e marcações, com traços, cores, setas, etc.

Dois detalhes: desde as cópias ampliadas do segundo manuscrito (cf. figura 19) que entreguei a Jessica, usamos sempre o tamanho A3 para a partitura, para facilitar a leitura a alguma distância. E a disposição da página em paisagem ("deitada") ajuda a dar a ideia de fluxo contínuo, com menos quebras de sistema. Por que falo desses detalhes agora?

Porque eles implicam usar uma estante maior para apoiar a partitura. Como finalizamos a peça a pouco tempo da estreia, infelizmente não foi possível retirar 
MIRANTE, OU UM HORIZONTE A VOZES MUITAS $\cdot 83$

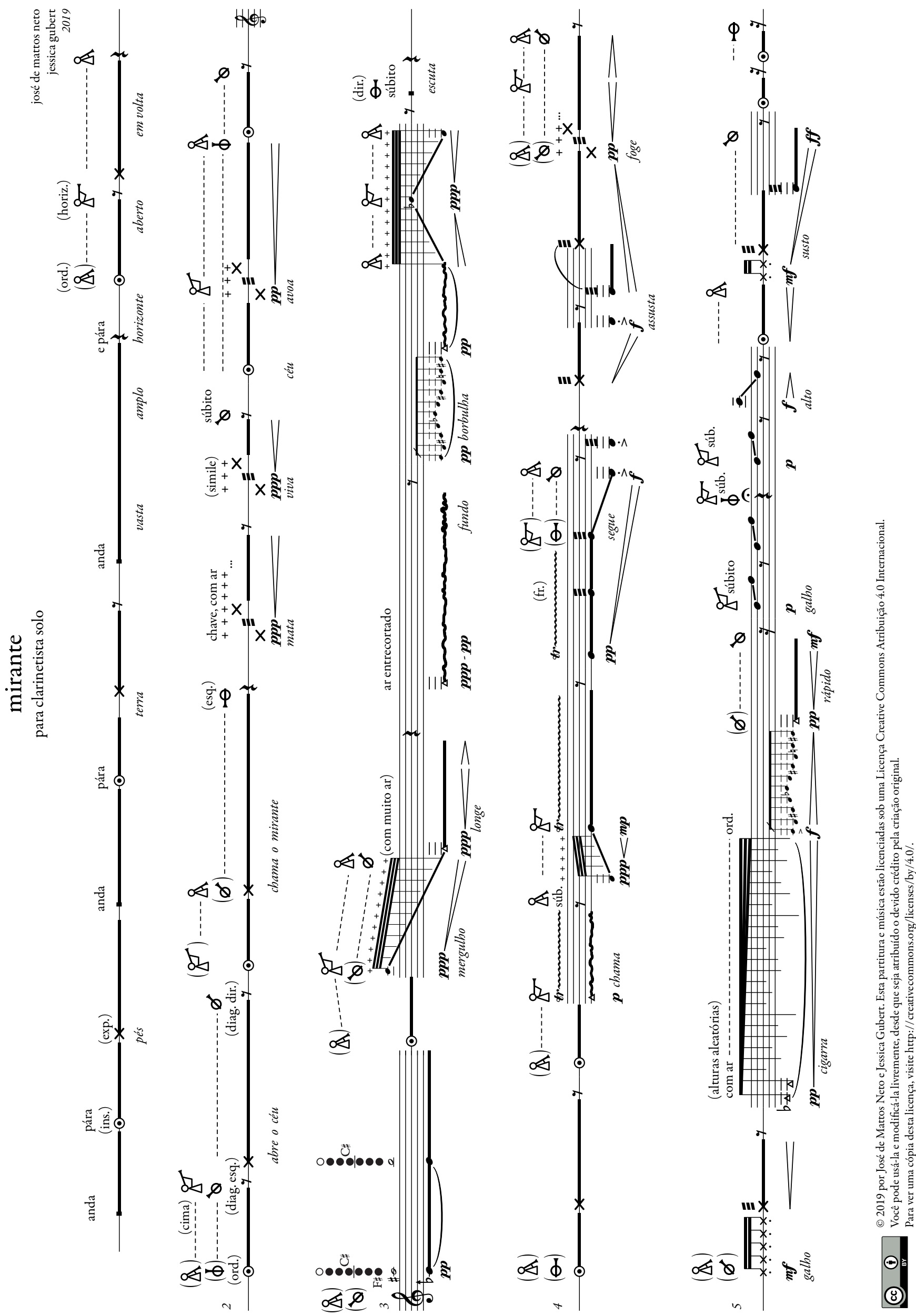

Figura 26: Primeira página da partitura usada na estreia de Mirante, em que faltam algumas mudanças decididas em ensaio. 

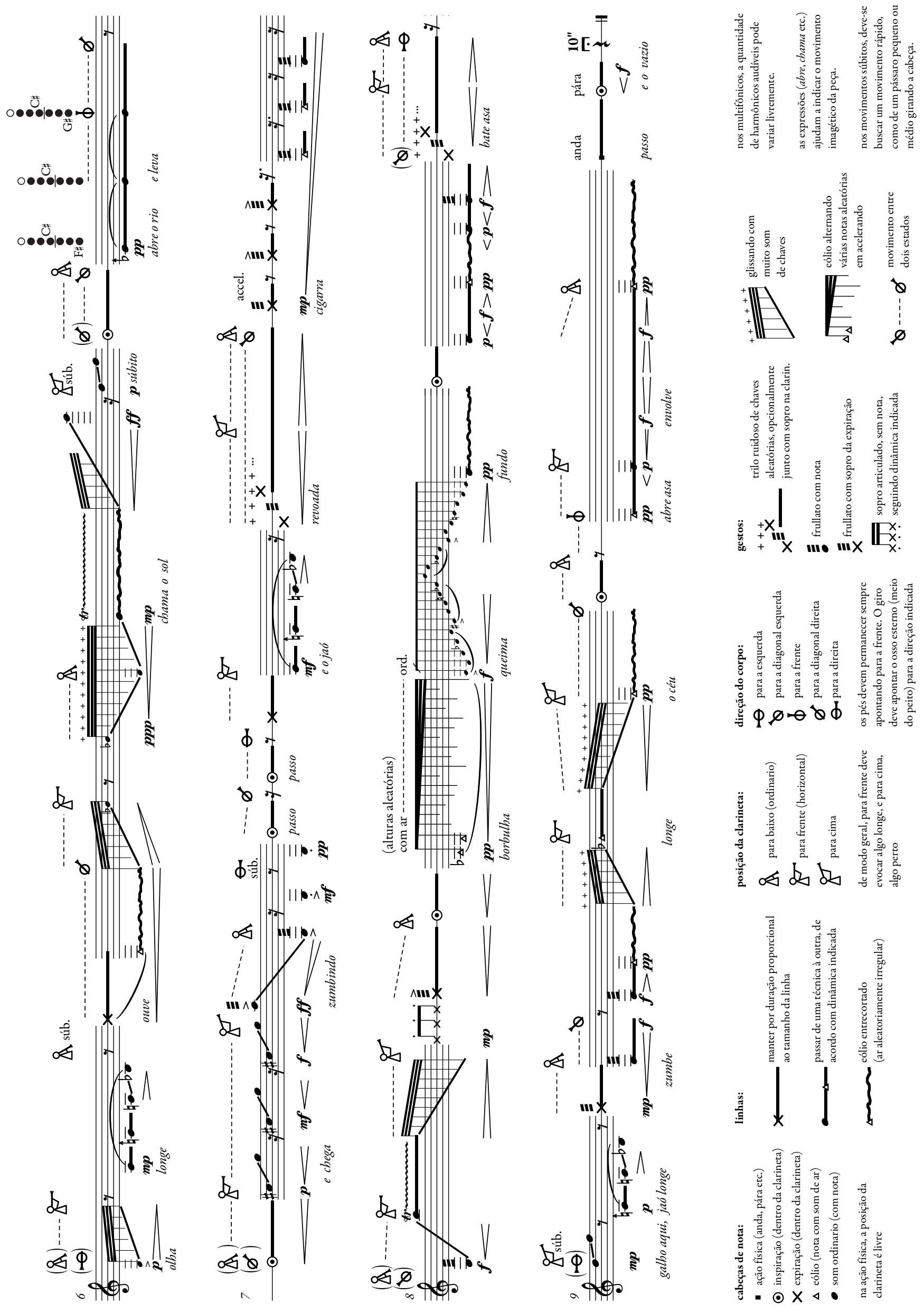

Figura 27: Segunda página da partitura usada na estreia de Mirante, em que faltam algumas mudanças decididas em ensaio. 
a partitura da performance. Assim, por sugestão de Silvio Ferraz e Luís Afonso Montanha, usamos duas estantes que podiam deixar a partitura mais baixa e inclinada, para que elas não ficassem na frente dos gestos de Jessica.

Mirante seria estreada na mostra semestral do Laboratório de Interpretação e Criação Contemporânea (já citado). No dia da apresentação, o local, o Espaço das Artes da USP, estava sendo usado por professores e alunos do Depto. de Artes Visuais da ECA-USP, que montavam uma outra mostra distribuindo quadros, objetos, diversos trabalhos pelas salas. O que era de início uma confusão no agendamento de horários do espaço se tornou uma oportunidade de justapor aqueles trabalhos e as performances do laboratório. Jessica e eu preferimos posicionar a Mirante na sala inicial, o Átrio, de forma que o som frontal forte do final da peça (cf. final da partitura da figura 27) se direcionasse para um corredor para outras salas, preenchendo e ecoando por todo o espaço. Além disso, passamos trechos da peça e percebemos que o tempo grande de reverberação misturava gestos sonoros muito rápidos; ao mesmo tempo, sons mais sutis eram valorizados, como os das chaves da clarineta. Um tempo mais calmo dos gestos.

Mas Mirante não foi a única peça a ser tocada no Átrio. E, para experimentar um fluxo da mostra com transições rápidas entre performances, Silvio Ferraz me pediu para distribuir as performances (todas solo) naquela sala de modo que cada musicista permanecesse no lugar durante as outras performances. Quadros e trabalhos (do outro evento sendo montado) e performers, espalhados pelo espaço grande daquela sala ${ }^{52}$.

Por um lado, o esvaziamento do espaço, tão falado por Brook (2000) e Oida (2007, p. 22), era impossível por essa disposição das performances. Mas, por outro lado, ela gera algo interessante: a modulação de uma performance por outra - tudo pode se transformar.

$$
\begin{aligned}
& \text { (...) colocados lado a lado, dois fluxos de energia sempre entram em } \\
& \text { modulação. (...) o que temos é um momento súbito em que as relações } \\
& \text { estão abertas e todas por serem feitas pelo ouvinte. (...) podemos } \\
& \text { pensar que qualquer partícula modula qualquer outra, que uma } \\
& \text { energia mínima pode modular uma energia potencial maior do que } \\
& \text { ela. (FERRAZ, 2014, p. 26) }
\end{aligned}
$$

Não apenas as performances se modularam: elementos ínfimos também tinham essa capacidade - como por exemplo os óculos escuros de Montanha (visível no registro da figura 28), que, escolhidos por ele no dia da apresentação, modularam não só a peça que ele tocou mas todas as outras, acrescentando um elemento estranho e cômico a um "cenário" já tão atípico.

Houve algo semelhante nos sons. Em uma sala afastada, acontecia a ativação de uma

${ }^{52}$ As outras peças que foram tocadas no Átrio na ocasião: Moldura III de Gustavo Bonin, com Luís Afonso Montanha no clarone (visível ao fundo no registro da figura 28); Praia do mesmo compositor, com Marta Brietzke no violoncelo; e Cantabile e Le Tombeau de G. Olivier Toni de Willy Corrêa de Oliveira, com Gustavo Fontes no contrabaixo. 
arte sonora que, devido à ausência de portas no espaço, preenchia às vezes toda a área interna do Espaço das Artes ${ }^{53}$. Embora sua sonoridade fosse geralmente sutil, com sons contínuos e que apareciam/desapareciam gradualmente, sua presença sonora também modulou outras performances - para mim, a sensação foi de algo etéreo acontecendo. Tal presença sonora pode ser ouvida em alguns momentos do registro da figura 28.

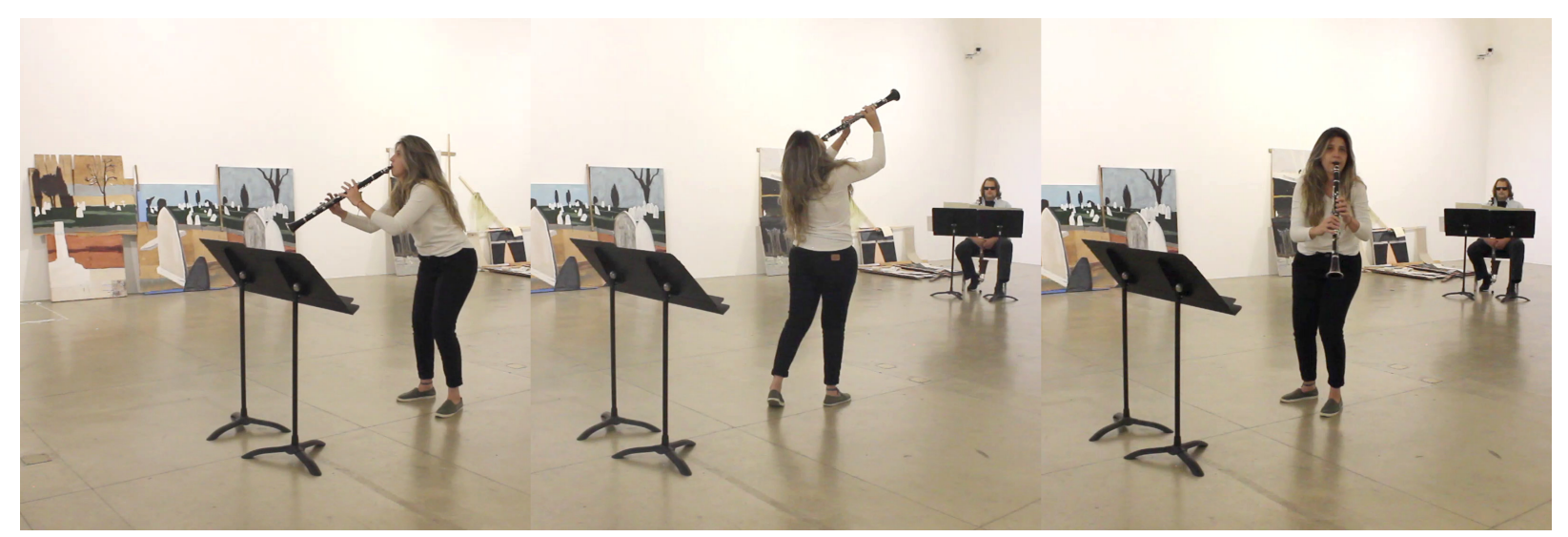

Figura 28: Registro da estreia de Mirante no Espaço das Artes, em 24 de junho de 2019, na mostra Inacabados e processos. Disponível em https : //youtu . be/6-aIv0695MM (acesso em 10 nov. 2020).

Assim, Mirante foi estreada no dia 24 de junho de 2019, na mostra Inacabados e processos do laboratório já citado. Um registro dessa apresentação está disponível na figura $28 \mathrm{e}$ em https://youtu . be/6-aIv0695MM (acesso em 10 nov. 2020). Na ocasião, pudemos experimentar como a presença do público age sobre a performance da peça: o olhar de Jessica parecia mais vivo e atento, em comparação com as diversas passagens da peça que fizemos nos encontros. Apesar do pouco tempo para finalizar o estudo das passagens finais, a performance correu do início ao fim, e a postura de Jessica no último gesto, diante do vazio, do abismo do mirante, foi mais viva do que nunca.

Ainda assim, não tivemos tempo para aprofundar diversas questões: a distância dos gestos, de que falei antes, foi trabalhada em apenas um ensaio com o exercício de improvisar com pássaros e ambiente; também os exercícios da caminhada inicial foram feitos apenas uma vez. E, de modo geral, embora Jessica tenha encadeado e dado fluxo aos gestos naquela apresentação, percebi que vários trechos devem ser reescritos. Por exemplo, o gesto de revoada - em que ela faz os sons de chaves com a clarineta fora da boca, desenhando com ela um arco no ar - acontece muitas vezes na peça, e quase sempre num encadeamento que o leva a um desacelerar.

Na verdade, a parametrização dos movimentos - em três (ou quatro) direções, e em três posições da clarineta - embora tenha ajudado a delineá-los e limpá-los, acabou, com o tempo, se tornando um entrave à vivacidade. Talvez seja algo parecido com o que nos fala Yoshi Oida (2007, p. 43), quanto à marcação dos movimentos no espaço de cena em oito direções (como uma estrela de oito pontas): embora uma interpretação

${ }^{53}$ A arte sonora em questão é LaptopScape, de Luzilei Aliel e João Monnazzi. 
mais estilizada possa usá-las de forma bem definida, numa atuação mais realista isso não precisa ser tão óbvio; mas estar atento a elas pode nos dar "uma qualidade muito nítida com relação ao espaço", ao mesmo tempo que as ações continuam sendo naturais - e isso vale tanto para a interpretação estilizada como a realista.

No segundo semestre de 2019, não conseguimos continuar o processo de Mirante, por dificuldades de agenda de ambos os lados. Assim, havíamos planejado para 2020 um trabalho mais focado no corpo, incluindo a ajuda da professora Alice K. (do LAt! citado), do Depto. de Artes Cênicas, além de uma reescrita total da peça a partir de experimentações e improvisações, tanto no campus da USP onde está a ECA como na própria Chapada dos Guimarães, no Mato Grosso. Mas a pandemia de Covid-19 inviabilizou esse trabalho, infelizmente. Pretendemos realizá-lo ainda (quando for possível dado o distanciamento social da pandemia de Covid-19), talvez já em 2021.

Porém, ao longo desse segundo semestre de 2020 em que escrevo, dentro de seu próprio mestrado em Performance, Jessica está organizando um recital em vídeo, a partir da gravação audiovisual de diversas peças - entre elas, a Mirante, que foi gravada na própria Chapada dos Guimarães. Esse recital deve ser lançado em breve, mas na figura 29 há fotos da gravação da peça em meio à mata; e a gravação em áudio está disponível em https://soundcloud.com/josedemattosneto/mirante (acesso em 26 nov. 2020). Nesse mesmo período, ela me escreveu o texto da seção 3.1. Como remontar essa peça depois das queimadas criminosas que consumiram o Pantanal, o Cerrado, a Amazônia, que mataram tantos, incontáveis animais pelo caminho do fogo? Como tocar na mata queimada?

Mirante, para mim, foi - ou tem sido - um processo muito especial, por diversos motivos. Primeiro, por proporcionar esse encontro de vozes, ideias, práticas, esse encontro com Jessica, que, além de carregar consigo um estudo minucioso e versátil da clarineta, é aberta a experimentar o desconhecido, a se jogar no abismo, e principalmente a participar ativamente da criação trazendo suas referências, suas reflexões e sensações do mundo. Sem que esperássemos por isso em 2019, a peça ganhou uma dimensão política terrível, ao ser remontada por Jessica em meio às queimadas de 2020. Foi também o momento de juntar dois ambientes que, na minha prática até então, estavam ainda muito separados: as práticas e o pensamento da cena, e a presença da partitura no processo composicional e criativo.

E ainda mais outro ambiente: a poesia. Ao colocar as imagens poéticas na partitura, passei a compor atravessado - de maneira mais explícita - pela minha prática poética, que até então eu deixava de lado, como uma atividade menor na minha prática artística. Abrir um amplo e vasto espaço, senti-lo na composição. 
vento sopra longe

corre o peito os ossos fundos

horizonte brota

das mil vozes

a queimar

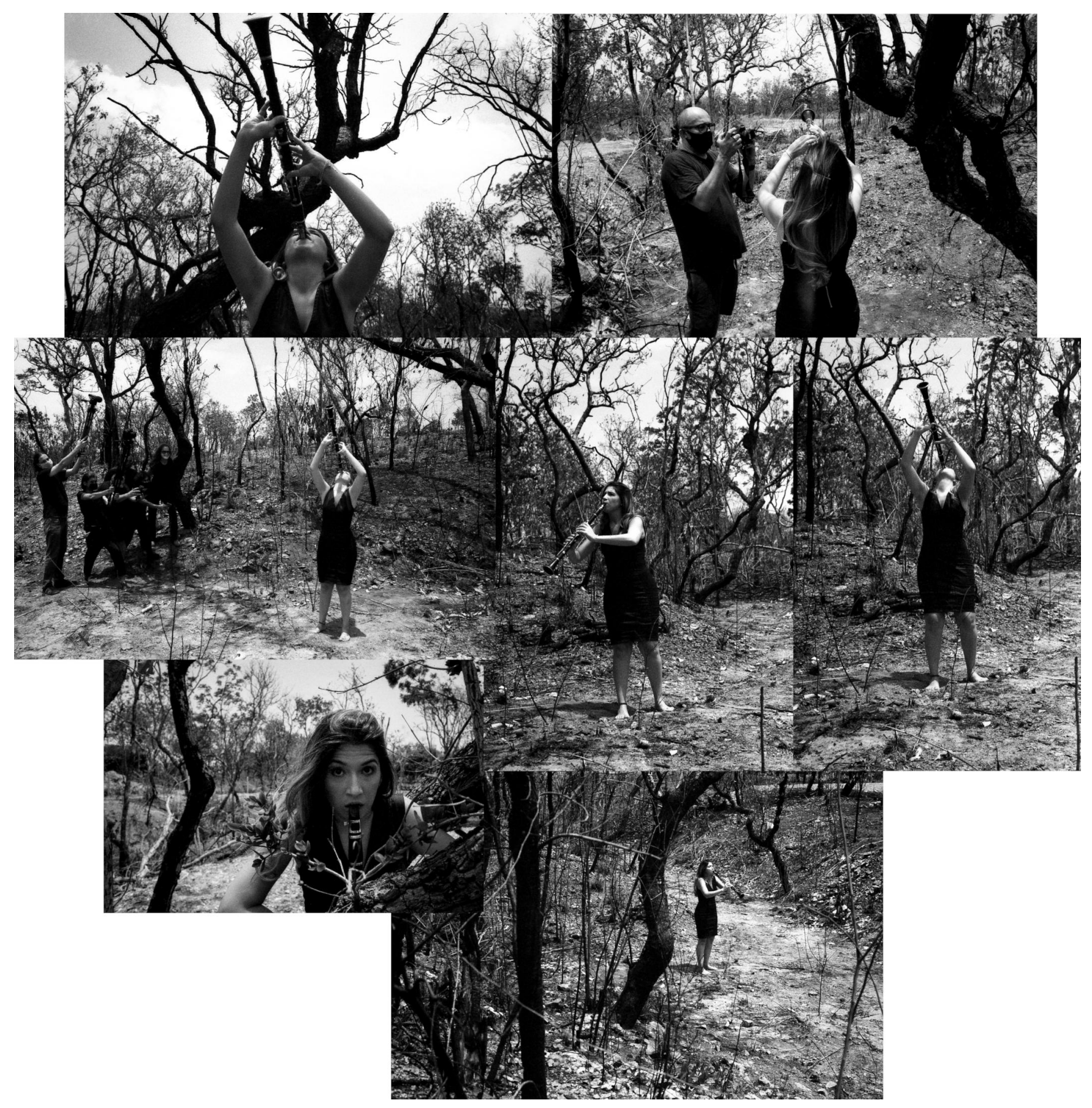

Figura 29: Jessica grava Mirante em meio à mata da Chapada dos Guimarães, em outubro de 2020. Áudio (não masterizado) disponível em https://soundcloud.com/josedemattosneto/mirante (acesso em 24 nov. 2020). Fotos por Pedro Thame. Captação, edição e mixagem por Manoel Neto. 


\title{
4 AZUL, OU CRIAR NO REFLEXO DOS GESTOS
}

\author{
confiar no cair \\ por todas as peles terras \\ e nervos
}

Os dias passam incessantemente parecidos uns com os outros. As paredes, iguais; as ruas, ora fervilham de gente, ora sopram o vento da peste - parecem nos dizer, "não sairemos dessa tão cedo", ou algo no tom. O sol já pendulou até o máximo de inclinação, e daqui a um mês e meio deve atingir a linha do solstício de verão; o frio, a chuva, o calor passaram, e as paredes seguem. $O$ inferno de queimadas, apagões e indiferença; o espetáculo de péssima categoria dos palácios tornados quartéis proféticos, show regado a veneno e sangue; a desgraça segue e se alastra, mas os dias passam incessantemente.

Tudo o que era de antes, de antigamente, quando a presença era possível, tudo parece longe, e lembrar de um evento cheio de gente leva de um salto à pergunta, "como era possível?" Assistir a uma performance, ver e ouvir a música brotando ali, de pessoas na nossa frente, de corpos vivos em que corre sangue e ar; estar no palco sentindo as respirações e humores dos que assistem e dos que também estão no palco, nadar no fluxo que corre entre corpos, sons, cheiros, vozes, cores e luzes. Existe algo que corre entre corpos presentes, que me parece não correr através das telas. "Como era possível?"

As telas são muito iguais. As mesmas falhas, a mesma lógica retangular a cansar os olhos e a coluna. O mesmo som. Rachado, comprimido, achatado. O som da videochamada, o som da videoconferência, o som que nos é possível no momento ao menos para alguns de nós. O som não muda. Claro, identifico a voz que fala comigo, essa unicidade maravilhosa permanece, mas é recortada e tornada ofegante pelas falhas dos sistemas (e os olhos não se cruzam).

De modo que me parece estranho, num momento (estirado) como esse, perguntar como performance e desenho podem se relacionar. Há um quê de teórico, ou de teoricismo, nisso. No retângulo das videotransmissões geralmente não cabe nem o corpo todo da/o musicista, quanto mais um desenho; e ainda mais longe a relação entre os dois. Mas mantenho a pergunta, porque falo de processos de "antigamente" que seguem, através mesmo da peste. Como performance e desenho podem se relacionar?

Um caminho possível é o processo de Respire, do capítulo 2. Ali, voz e desenho são o rio em que corre a performance. Como nos diz o mestre Naná Vasconcelos ${ }^{54}$, "o

${ }^{54}$ A citação é de uma entrevista em vídeo de Naná Vasconcelos (DIÁRIO DE PERNAMBUCO, 2015). 
primeiro instrumento é a voz", essa nossa existência sonora no espaço; no contato com o desenho, a voz (se) transforma. Mas e outros instrumentos? O que acontece ao juntar performance instrumental e desenho?

\subsection{O desenho e o arco}
folhas leves vibram
ao vento que curva os galhos
sem começo nem fim

Em março de 2019, Giovanna Airoldi me pediu para compor uma peça para seu Recital de Conclusão de Curso (Música com habilitação em Instrumento). Na época, orientada por Silvio Ferraz, ela estava escrevendo uma monografia sobre sua pesquisa de Iniciação Científica, em que se debruçava nas diferentes relações entre desenho e música, tanto para compositoras/es como instrumentistas. Violoncelista, ela desejava uma peça para seu instrumento, mas não só a peça: queria principalmente relatar, na monografia, seu processo de estudo através de desenhos, além do meu processo composicional.

Já nos conhecíamos de um processo anterior, de $2016^{55}$, mas sabíamos pouco da pesquisa um do outro, embora tivéssemos o mesmo orientador. De modo que marcamos uma primeira conversa, no dia 20 de março de $2019^{56}$, para entendermos melhor de onde partir. Numa sala de estudos do Depto. de Música da ECA-USP, apresentei a ela tanto o tema da minha pesquisa de Mestrado como as peças que compus com alguma notação ou influência gráfica, além, é claro, da escrita-desenho da respiração (cf. capítulo 2). Em contrapartida, ela me falou tanto de sua própria pesquisa como das peças que preparava para seu recital: Cinco Mo(vi)mentos de Alexandre Ficagna, Sept Papillons de Kaija Saariaho, À deriva de Marisa Rezende, além da Sonata para violoncelo solo de George Crumb.

A pesquisa de Giovanna ${ }^{57}$, que vinha desde sua Iniciação Científica, envolvia as relações entre música e desenho, partindo da reflexão teórica de dois pintores, Paul Klee e Wassily Kandinsky, da influência dessas reflexões sobre alguns compositores como Salvatore Sciarrino, Iannis Xenakis, Gyorgy Kurtag e Alexandre Ficagna - , e de seu próprio uso do desenho como ferramenta de estudo do violoncelo e do repertório.

55 O processo em questão foi da peça Colapso (flauta em G, clarineta, clarone e violoncelo), que compus dentro das práticas do Laboratório de Interpretação e Criação Contemporânea (Depto. de Música da ECA-USP) ao longo do primeiro semestre de 2016.

${ }^{56}$ Assim como no processo do capítulo 3, gravei vários dos encontros que tivemos - alguns em vídeo, outros apenas em áudio. Para relatar o processo desse capítulo, uso também como referência o Trabalho de Conclusão de Curso de Giovanna Airoldi (2019), em especial a seção 2.4, em que ela relata tais encontros.

${ }^{57}$ Assim como em outros capítulos, escolho usar o primeiro nome de Giovanna Airoldi para retomá-la no texto, em vez de seu sobrenome. 
$\mathrm{Na}$ ocasião daquela primeira conversa, ela me explicou que a ideia do processo, vinda de Silvio Ferraz, era que

$$
\begin{aligned}
& \text { juntos desenvolvêssemos uma peça em que o desenho fosse a } \\
& \text { figura central da criação musical, servindo como recurso tanto } \\
& \text { da interpretação como da composição, um recurso para a criação } \\
& \text { conjunta entre compositor e interprete. (AIROLDI, 2019, p. 56) }
\end{aligned}
$$

Mas como fazer isso?

Uma primeira ideia que tive, durante a conversa, foi partir de uma imagem ou sensação que ela quisesse trabalhar no violoncelo. Pensei nisso a partir do processo da peça Luthieria, com o violinista Lucas Raulino (cf. início da seção 3.2), em que todo o processo se desenvolveu a partir de algumas imagens poéticas. Mas, para Giovanna, não havia imagens poéticas que lhe vinham à mente quando pensava sobre o que podíamos desenvolver.

Porém, ao longo da conversa, percebemos que outros caminhos talvez fossem mais interessantes. Giovanna sugeriu que criássemos uma imagem física, concreta, que as pessoas pudessem de alguma forma ver tanto na partitura como no momento da performance. Não tanto uma imagem poética, uma imagética da peça - como nas Sept Papillons de Saariaho, em que tanto os sons como os gestos de quem toca sugerem borboletas -, não; ela imaginava muito mais algo fisicamente presente.

Foi então que ela falou dos seus próprios desenhos, em que ela explorava tanto os fundamentos teóricos de Klee e Kandinsky como principalmente conceitos desenvolvidos por Salvatore Sciarrino (1998) em seu livro Le figure della musica. Como ela descreveu naquela conversa de 20 de março de 2019 , os desenhos que ela fazia eram "figuras que são uma explosão, ou uma multiplicação, ou acumulação, que partem de um ponto e vão crescendo"; neles, o ponto e principalmente a linha eram o centro do trabalho. Ou, para usar as palavras de sua monografia,

\footnotetext{
Levei para o encontro desenhos meus, (...) que já constituíam um vocabulário construído por mim dentro do meu referencial de imagem visual/imagem sonora. As ideias que desenvolvi a partir desse vocabulário e que são constantes nesses desenhos se baseiam nos conceitos de ponto, linha, plano, repetição, multiplicação, acumulação e forma em janelas. (AIROLDI, 2019, p. 56)
}

Algo interessante aconteceu quando Giovanna falou de seus desenhos: a conversa deixou de seguir por um caminho mais previsível - como uma "conversa para compor uma peça contemporânea", e passamos a discutir as motivações que a levaram aos temas de sua pesquisa. Desenhar, para ela, era algo próximo, familiar, tanto quanto a prática musical - a ponto de haver dúvida, quando do ingresso na graduação, sobre qual arte escolher, a música ou as visuais. A pesquisa sobre a relação entre desenho e música era, enfim, uma tentativa de interseção entre as duas atividades que, assim como a minha própria pesquisa, havia se modificado ao longo do tempo; justamente 
por isso, ela havia pensado em criarmos uma imagem concreta, fisicamente presente na performance e na partitura.

\author{
correr o ponto \\ em curvas multiplicadas \\ cortar o papel
}

O desenho como prática era o lugar onde a violoncelista, ou mesmo a pesquisadora da música, dava lugar à Giovanna, uma multiplicidade que passa pela música como também por outras atividades - como toda pessoa, afinal - , era onde a Autora dava lugar à artista, para falar com Deleuze e Parnet (1998, p. 37-38) - semelhante ao discutido na seção 3.3. Uma unicidade, também, já que os caminhos e as maneiras pelas quais essas atividades se entrecruzam é diferente de todas as outras; uma unicidade, de certa maneira uma voz.

Assim como com Jessica Gubert (cf. o capítulo 3) foi sua relação com a Chapada dos Guimarães, no Mato Grosso, que trouxe à tona algo humano, algo que a diferenciava de qualquer outra musicista, era a relação de Giovanna com a prática do desenho que revelava o que de único poderia surgir num processo criativo com ela.

De certa forma, esses "lugares" - a Chapada dos Guimarães para Jessica, o desenhar para Giovanna - são também onde a prática musical, ou melhor, a Música deixa seus caminhos tradicionais, suas posições tradicionais, seu 'M' maiúsculo, e vaza por outros campos; e não somente a música vaza por outros campos, mas seus caminhos, suas linhas, suas práticas acabam soprando por outras janelas, bebendo de outros rios. É possível dizer que nesses lugares onde brota a unicidade relacional da voz de alguém, onde diferentes vivências/atividades/caminhos/linhas se entrecruzam de forma única, as posições tradicionais dentro da prática musical se diluem - o território da Música é desterritorializado, não por grandes movimentos de ruptura, mas por modulações pequenas em sua borda, em suas fronteiras; uma energia mínima que modula energias muito maiores que ela. (FERRAZ, 2014, p. 26, 28) É nesses lugares que talvez se possa produzir um outro pensamento:

\footnotetext{
É porque a filosofia nasce ou é produzida de fora pelo pintor, pelo músico, pelo escritor, a cada vez que a linha melódica leva o som, ou a pura linha traçada, a cor, ou a linha escrita, a voz articulada. Não há necessidade alguma de filosofia: ela é inevitavelmente produzida lá onde cada atividade faz brotar sua linha de desterritorialização. (DELEUZE; PARNET, 1998, p. 88, grifo meu)
}

Justamente aí, nesse lugar. Juntar, assim, desenho e prática musical. Uma imagem concreta, fisicamente presente na performance e na partitura. Mas havia um problema: se essa imagem concreta faria parte da (ou seria a) partitura, como indicar sons, técnicas e modos de tocar? Quais parâmetros usaríamos para construí-la? 


\subsection{Gestos feitos de tinta}

No dia 27 de março, Giovanna e eu nos encontramos novamente, no Depto. de Música da ECA-USP, para experimentar e discutir símbolos e gestos no papel que pudessem indicar diferentes técnicas e sonoridades. Elencamos dez gestos no violoncelo, para que tivéssemos um material diverso para a peça.

O que buscávamos, ali, não era simplesmente criar símbolos novos para gestos instrumentais, como uma simples tradução de um código antigo (notação tradicional) a um novo. Se o que queríamos era colocar o desenho como centro da criação musical, tal tradução não bastaria. Assim, a dificuldade que tínhamos era desenvolver símbolos que, de alguma forma, contivessem a energia dos gestos instrumentais, fosse por uma transposição do gesto instrumental ao do pincel (como gestos da mão direita, que segura o arco), ou pela energia mecânica sugerida pelo símbolo visual (como um traço vertical incisivo).

No encontro seguinte, em 17 de abril, experimentamos produzir juntos uma partitura com aqueles símbolos. Na ocasião, usamos nanquim e tinta aquarelável, e o papel de arroz como suporte (que eu já conhecia dos processos do capítulo 2), porque pensávamos que, com isso, teríamos uma liberdade maior no gesto do pincel, gerando manchas amplas a partir de um só gesto. Dispusemos a folha de papel de arroz (que media em torno de $110 \times 80 \mathrm{~cm}$ ) no chão, sentamos em frente a seus lados maiores (um de frente para o outro) e desenhamos um fluxo de gestos. Definimos um sentido de leitura mais tradicional, com o eixo horizontal relativo ao tempo e o vertical, às alturas; mas não combinamos o que aconteceria, que sequências de gestos haveria. $\mathrm{Na}$ figura 30 , o resultado desse experimento está disposto como pretendíamos que fosse lido, a partir da posição em que Giovanna estava ${ }^{58}$.

Depois de fazermos essa partitura, Giovanna experimentou lê-la com o violoncelo. Evitamos discutir o desenho antes dessa leitura, para verificarmos a efetividade dos símbolos que havíamos definido. Ela tentou

$$
\begin{aligned}
& \text { ser o mais literal possível, tocando cada gesto como havia sido pensado } \\
& \text { no início, sem adicionar nada que não estivesse escrito. Isso a tornou } \\
& \text { uma execução com um fluxo de energia alto e constante, mas com } \\
& \text { pouco espaço para respiros. (AIROLDI, 2019, p. 60) }
\end{aligned}
$$

Como ela relata na sua monografia, essa primeira leitura lhe pareceu, naquele momento, uma improvisação. Por quê? Embora os parâmetros - duração, altura, técnica - estivessem indicados, eles não eram exatos, havendo uma margem de liberdade para construção durante a performance. Mas essa liberdade seria exclusiva de uma partitura gráfica?

Como nos diz Cook (2006, p. 12), "a performance rotineiramente requer não tocar o

\footnotetext{
${ }^{58} \mathrm{Na}$ figura 30, grosso modo, a metade superior foi desenhada por mim, e a inferior, por Giovanna.
} 


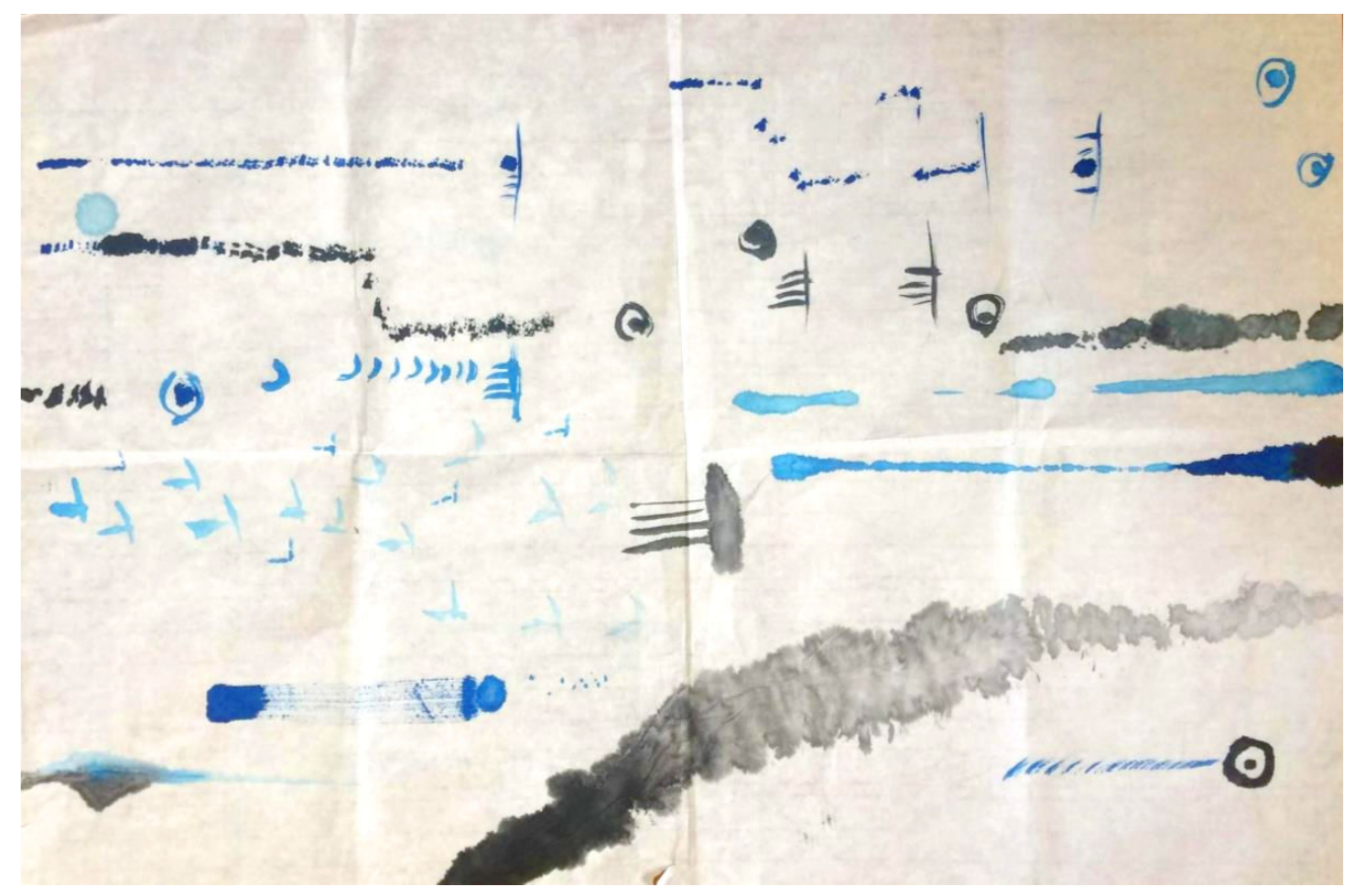

Figura 30: Partitura gráfica colaborativa, produzida em 17 de abril de 2019, com tinta aquarelável, nanquim e papel de arroz. Para os símbolos usados, cf. figura 32.

que está grafado, e vice-versa; neste sentido, há uma incomensurabilidade entre o detalhe da notação e o detalhe da performance". Não é exatamente o caso, assim, de definir a partitura gráfica como menos detalhada que a convencional, já que ambas abarcam universos de detalhes distintos dos da performance. Antes, a sensação de estar improvisando ao ler uma partitura gráfica tem muito mais a ver com hábito: aprendemos e desenvolvemos nossa prática musical por anos a fio usando partituras convencionais, de modo que uma tal mudança no tipo de notação gera um estranhamento a princípio - tanto em Giovanna como em mim.

Mas havia um outro estranhamento: ela havia participado na criação, na feitura mesma daquela partitura. Depois da leitura, discutimos o desenho, o que cada um pretendia a cada momento do fluxo, e percebemos que não tínhamos uma consciência plena de todos os gestos desenhados. De modo que a pergunta "o que você queria nesse momento?", comum em uma conversa entre quem compõe e quem toca, era deslocada de lugar.

Cabe dizer que Giovanna fez uma segunda leitura, na ocasião, dessa vez podendo passear livremente pela partitura, sem necessariamente respeitar sequências ou sistemas. Aqui, o estranhamento foi ainda maior: sentimos que tamanha liberdade na leitura acabava diminuindo, ao menos naquele momento, a multiplicidade de sons e gestos instrumentais. Além disso, sentíamos a necessidade de elaborar e definir melhor os símbolos, para que tanto a partitura gráfica como a performance pudessem ser mais trabalhadas.

Em um encontro posterior, no dia 24 de abril, nos encontramos na sala 19 do Depto. de Artes Cênicas da ECA-USP. Na ocasião, depois de uma longa experimentação que descrevo mais a frente (cf. seção 4.3), propus que Giovanna lesse novamente 
a partitura da figura 30, já que na ocasião contávamos com uma câmera, além do habitual gravador de som. Ela fez duas leituras, registradas ${ }^{59}$ e disponíveis em https ://youtu.be/YOjYe6nDDFk e https://youtu.be/kbTiNpmy5bI (acesso em 19 nov. 2020), e na figura 31. Um dos objetivos dessas leituras registradas em vídeo (além do próprio registro do processo) era que eu pudesse saber que gesto instrumental ela havia feito a cada momento, já que tive dificuldades nisso somente com o áudio.

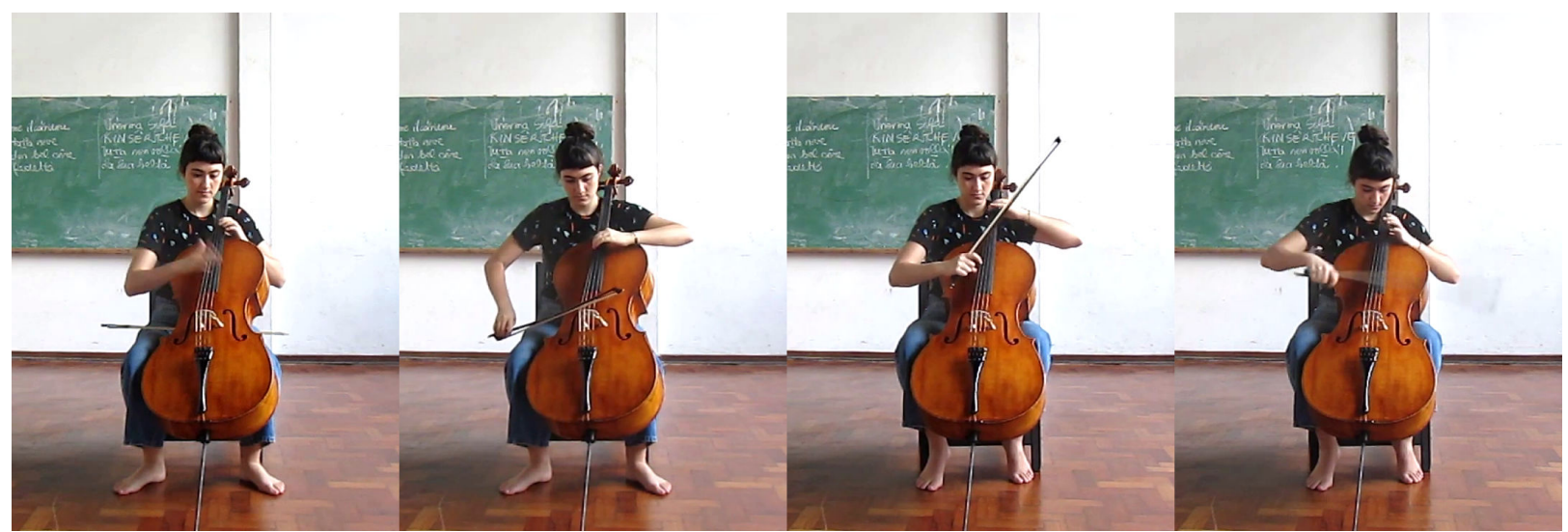

Figura 31: Duas leituras da partitura da figura 30, em quatro momentos, na sala 19 do Depto. de Artes Cênicas da ECA-USP. Disponíveis em https://youtu.be/YOjYe6nDDFk e https://youtu.be /kbTiNpmy5bI (acesso em 19 nov. 2020).

Nessas leituras, percebemos que aquele estranhamento inicial, de que falei antes, havia em parte se perdido. Se isso por um lado trazia uma ênfase maior em alguns gestos, levou também a uma certa fragmentação do fluxo da performance. Como Giovanna diz em sua monografia, "a mudança abrupta entre um gesto e outro ficou muito evidente sem parecer proposital, e os momentos de silêncio entre os gestos também não soavam intencionais". (AIROLDI, 2019, p. 62) Aliás, o silêncio voltaria a ser uma questão no processo posteriormente, conforme relato mais adiante.

A partir dessas experiências, marcamos uma reunião com Silvio Ferraz, nosso orientador. Tínhamos a percepção de que a primeira leitura de 17 de abril, logo depois de fazermos a partitura da figura 30, havia sido a mais interessante. Assim, combinamos que eu faria uma transcrição do áudio daquela leitura para levar à reunião, usando os símbolos que havíamos definido. Mas, ao invés de uma folha grande dividida em sistemas, usaria uma longa tira de papel de arroz (como havia feito em 2018, cf. figura 8 e capítulo 2), para melhorar a continuidade da leitura.

Falo dos símbolos que definimos (e eles já apareceram na figura 30), mas quais são? Para essa transcrição, fiz uma espécie de bula, disponível na figura 32, buscando registrar o que havíamos desenvolvido nos encontros. É importante notar que, enquanto a maioria dos símbolos permanecia a mesma desde o encontro do dia 27 de março, alguns foram modificados: a indicação para ponto de contato do arco (entre sul ponticello e sul tasto, SP e ST), que era por intensidade do pigmento e passou a ser pela

59 Infelizmente, posicionei a câmera na ocasião de um modo que ocultou a própria partitura, disposta no chão à frente de Giovanna. 


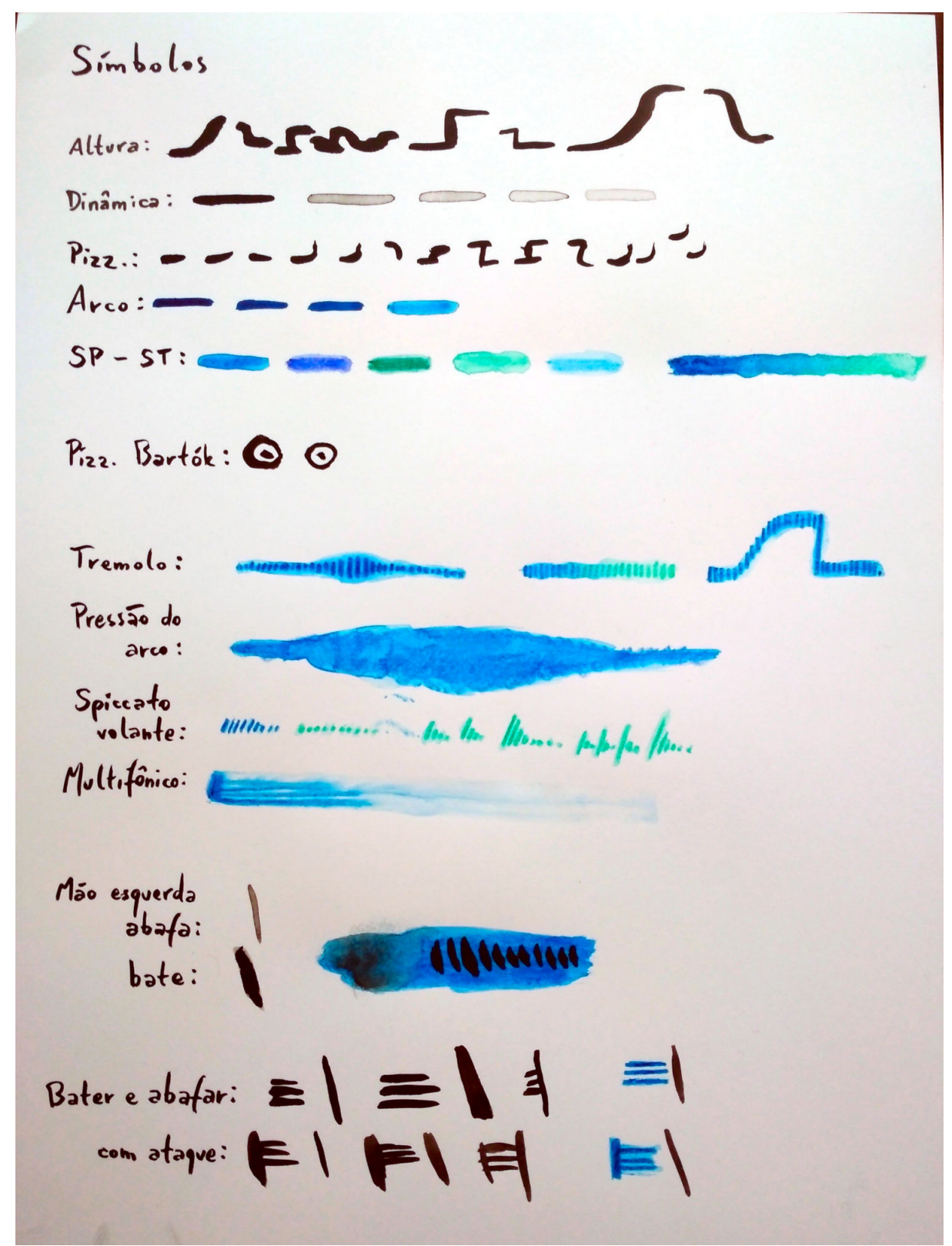

Figura 32: Símbolos gráficos definidos ao longo do processo, usados tanto na partitura da figura 30 como em transcrição posterior de áudio.

cor; e tremolo, que era uma linha oscilante e passou a ser uma pincelada preenchida por pequenos riscos.

No dia 7 de maio na sala 12 do Depto. de Música da ECA-USP, tivemos o encontro com Silvio Ferraz. Na ocasião, mostramos a partitura da figura 30, explicamos o processo até aquele momento, e então Giovanna leu a partitura em tira que eu havia confeccionado. Essa leitura está disponível em https : //youtu . be/rxWEtCKUZSg (acesso em 19 nov. 2020) e na figura 33. A tira trazia a vantagem de marcar de forma mais contínua o fluxo temporal, mas tinha um inconveniente: precisava ser movida durante a leitura, semelhante talvez a um rolo de pergaminho (cf. terceiro momento da figura 33 e também início do vídeo correspondente). Além disso, os espaços em branco - os silêncios - ainda tendiam a esvair o fluxo, mesmo usando a tira. E, de modo geral, para além dos silêncios, sentíamos que a performance não andava, não ganhava vida. 


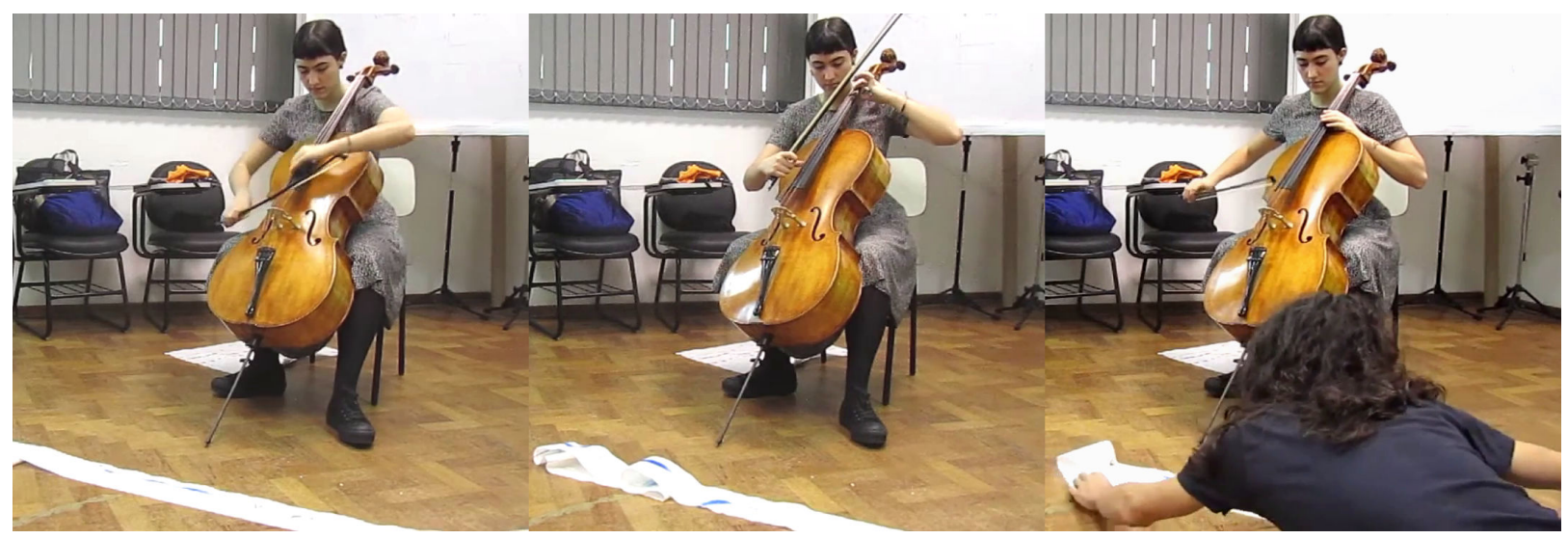

Figura 33: Giovanna lê a transcrição do áudio de encontro anterior, em orientação com Silvio Ferraz na sala 12 do Depto. de Música da ECA-USP. Disponível em https : //youtu . be/rxWEtCKUZSg (acesso em 19 nov. 2020).

Silvio nos explicou, então, que um dos motivos para a performance não andar era que os gestos instrumentais não se conectavam, não entravam uns nos outros. Ele nos mostrou, no violoncelo de Giovanna, como poderíamos transformar um tremolo em um gesto totalmente diferente, por exemplo, e com isso ganhar um dinamismo, um movimento fluido na performance. Mas como fazer isso a partir do desenho?

Ou antes: por que a partir do desenho? Ele era, como já dito, o centro do processo, mas isso não significava necessariamente que tudo tivesse que partir dele. De que outra maneira poderíamos juntar música e desenho?

\subsection{O espelho}

Desenhar e vocalizar. Voz que nasce com o traço, pincel que corre com o sopro. Corda que vibra com a mancha do pincel - como?

Um dos desejos de Giovanna que discutimos naquela primeira conversa, de 20 de março de 2019, era desenhar enquanto tocava violoncelo. Por mais que ela também desejasse que houvesse uma imagem concreta na partitura e na performance, $o$ que havíamos feito até então separava temporalmente as duas ações, desenhar e tocar. Uma questão que surgiu foi justamente se era possível juntá-las num mesmo momento.

Uma possibilidade seria gerar o desenho digitalmente a partir dos gestos corporais instrumentais de Giovanna, o que envolveria um aparato tecnológico e, principalmente, um trabalho de pesquisa e programação para definir como os gestos dela seriam convertidos em parâmetros para o desenho. Esse caminho não nos atraiu naquele momento, já que não trazia a materialidade da tinta, dos materiais - o que desde o início nos interessava.

Foi então que me lembrei de uma prática com que tive contato no Laboratório de 
Atuação ${ }^{60}$ (LAt!), que consistia, basicamente, em duas pessoas que devem saltar juntas à frente algumas vezes, sem combinar o momento do salto. A partir dessa e de outras práticas, vividas naquele laboratório e em outros processos em artes cênicas, propus que tentássemos fazer um espelhamento corporal: ela com o violoncelo, eu com os materiais de desenho. Assim, em vez de acoplarmos à sua performance um aparato tecnológico para produzir o desenho, essa etapa seria feita por mim, por um corpo vivo.

Essa proposta era, também, um desdobramento do que eu havia feito em 2018, junto a um grupo de artistas, na performance Respire (cf. capítulo 2); mas aqui, o desenho seria feito junto com a performance, e a dimensão sonora caberia principalmente a Giovanna com o violoncelo. Cabe lembrar que, até aquele abril de 2019, não havia nem sequer pensado em remontar Respire incluindo o desenho na performance (como relato na seção 2.6).

No encontro já citado do dia 24 de abril (cf. figura 31), fizemos essa proposta. Mas a prática do LAt!, na qual ela era inspirada, acontecia dentro de uma longa preparação. Assim, preparei e conduzi aquecimentos ${ }^{61}$ seguindo um caminho que partia de um corpo mais cotidiano:

1. Relaxar e ativar os pés, pernas, quadril e coluna vertebral, por meio de alongamentos, da atenção no relaxamento e da ampliação da respiração;

2. Perceber o peso e o movimento do corpo pelo espaço a partir do quadril;

3. Atentar ao impulso interno do movimento, ao primeiro impulso, por meio do salto em dupla;

4. Ampliar o olhar, por um movimento largo do corpo seguido de um olhar fixo em um ponto distante;

5. Conectar com o outro, pelo olhar e pelos movimentos, juntando os dois passos anteriores.

Com isso, pretendia chegar, com Giovanna, a um estado em que o espelhamento corporal fosse mais orgânico, mais direto; um estado em que corresse um fluxo entre os gestos instrumentais dela e os meus no desenho, com o mínimo possível de elaboração intelectual durante a performance. Logo depois dessa série de aquecimentos, experimentamos a prática - o espelho - pela primeira vez. Os aquecimentos e esse primeiro espelho estão disponíveis na figura 34 e em https : / /youtu. be/zQ8n58E196k (acesso em 19 nov. 2020).

${ }^{60}$ Já falei do LAt! no capítulo 3, mas cabe relembrar: ele acontece no Depto. de Artes Cênicas da ECAUSP, conduzido pela Profa. Dra. Alice K. Yagyu.

${ }^{61}$ Chamo de aquecimentos alguns exercícios simples que conheci em diferentes momentos e processos, tanto no LAt! como trabalhando como preparador vocal de grupos teatrais a partir de 2017, além, é claro, da troca com um grupo de artistas em 2018, descrito principalmente na seção 2.4. Também discuti o planejamento desses aquecimentos com Isadora Borges, que fazia parte daquele grupo. 


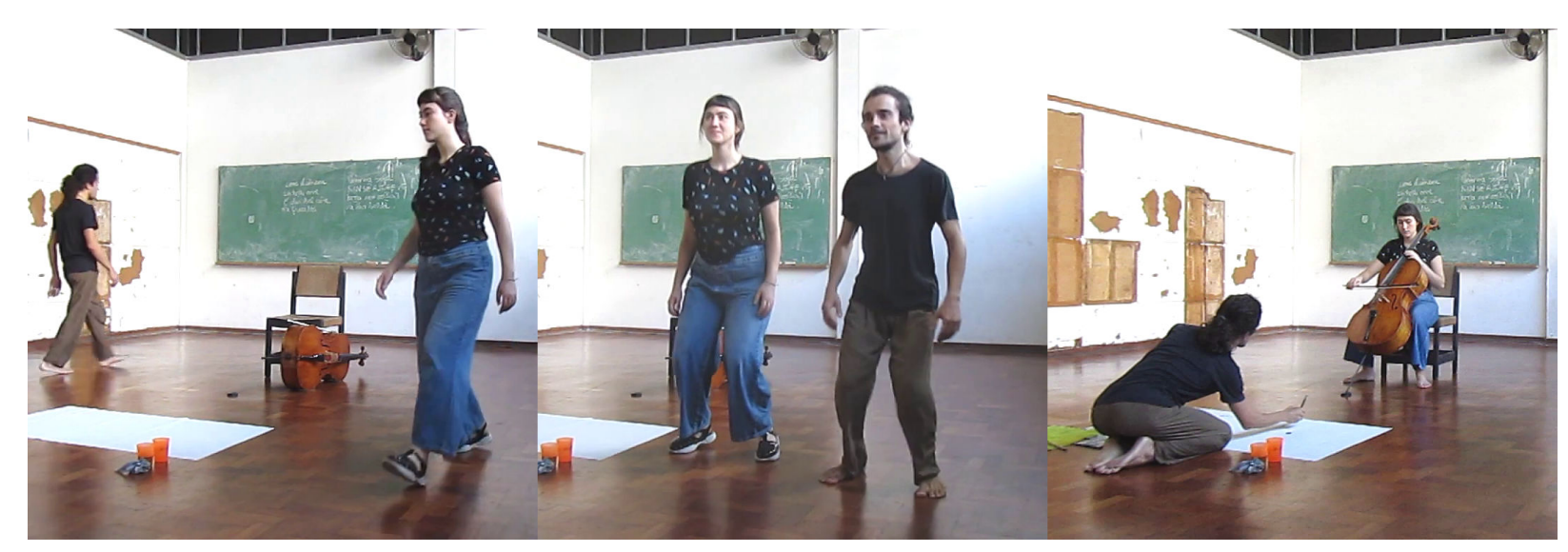

Figura 34:Aquecimentos e primeiro espelho, na sala 19 do Depto. de Artes Cênicas da ECA-USP. Disponível em https://youtu. be/zQ8n58E196k (acesso em 19 nov. 2020).

Mas logo percebemos alguns problemas. Primeiro, com os materiais: ainda usávamos nanquim, tinta aquarelável, papel de arroz e pincéis pequenos de sumi-ê, o que trazia uma dificuldade grande em pintar sem olhar para o papel, já que esses são materiais delicados; a tinta precisava constantemente ser carregada no pincel e, como esse gesto não se associava a nenhuma ação de Giovanna, ela interrompia seus próprios gestos; por isso, eu buscava carregar o pincel o mais rápido possível, errando muitas vezes na proporção entre água e pigmento que desejava. Segundo, com os símbolos: alguns deles não eram um espelhamento do gesto instrumental (como o pizzicato Bartók, cf. figura 32), gerando interrupções no fluxo e uma confusão quanto ao momento em que o gesto instrumental correspondente ocorreria. Terceiro, com os gestos instrumentais: como não sou violoncelista, a gestualidade de Giovanna não era orgânica para mim, o que gerava dificuldade e um atraso no espelhamento.

Ainda assim, realizamos mais dois espelhos, para verificar se algumas dessas dificuldades não podiam ser contornadas, depois de conhecidas. Esses dois espelhos estão disponíveis na figura 35 e em https : //youtu . be/polZxufDyRM e https : / / youtu . be /mz Je j TFo 810 (acesso em 19 nov. 2020). Algo que dificultou a prática nessas duas tentativas foi a perda gradual do estado que havíamos alcançado no aquecimento, tanto pelas dificuldades encontradas como pelos momentos em que parávamos para discutir o que havíamos feito. Mas, de qualquer forma, o que mais percebemos, naquele momento, é que a prática do espelho não era possível com aqueles materiais - como é possível ver no segundo e no quarto momento da figura 35 , em que carregar o pincel ou segurar o papel de arroz atrapalharam o fluxo. Como Giovanna diz em sua monografia, 


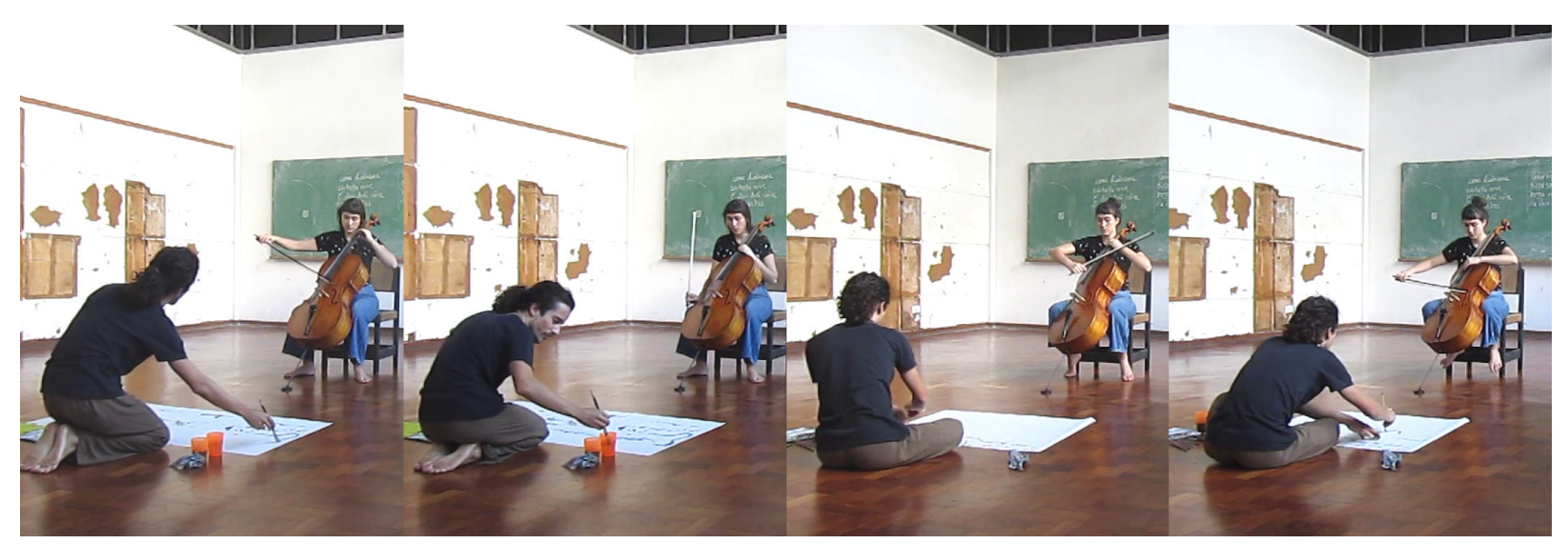

Figura 35: Segundo e terceiro espelhos em quatro momentos, na sala 19 do Depto. de Artes Cênicas da ECA-USP. Disponíveis em https : //youtu . be/polZxufDyRM e https : //youtu . be/mzJejTFo810 (acesso em 19 nov. 2020).

Assim, na reunião já citada com Silvio Ferraz, em 7 de maio de 2019, falamos dessas dificuldades (além da leitura da tira, cf. figura 33). Segundo ele, o momento de carregar tinta no pincel podia ser resolvido a partir de uma atitude mais consciente quanto ao silêncio: parar respirando, por exemplo, já que com isso as pessoas sentem essa respiração e vão junto conosco. Na verdade, respirar por toda a performance, nos seus ciclos de ir e vir, uma coisa viva. (FERRAZ, 2014, p. 22-23) E essa respiração, por sua vez, era algo que dependia, em certo grau, da visualidade e da presença da performance já que em uma gravação de áudio ela tenderia a desaparecer.

Mas talvez não "apenas" respirar: pensamos em incluir um som de Giovanna, um gesto fixo, nos momentos em que eu precisaria carregar a tinta. No dia seguinte à reunião, 8 de maio, em um encontro para debatermos aqueles problemas, pensamos em possibilidades para esse som/gesto: um ruído ou som contínuo? Um gesto cotidiano, como passar breu ${ }^{62}$ no arco? Um fragmento de peça do repertório? Depois de alguma discussão, preferimos um som contínuo, já que as outras possibilidades ou tomariam tempo demais (e não resolveriam os pequenos silêncios de gestos) ou mudariam muito o universo sonoro e gestual da performance. Tal som contínuo era feito pelo arco em molto sul ponticello, entre piano e pianíssimo, o que exigia, ao mesmo tempo, um movimento lento e constante.

Uma questão colocada por Silvio era que alturas, glissandi, tipos de arcada — que técnicas - Giovanna usava durante a performance; ou, mais precisamente, como mudar o condicionamento da técnica instrumental de modo a conseguir sonoridades não tradicionais. Sobre isso, ela comenta em sua monografia que

Desdoutrinar a técnica é um desafio que encontro na execução de muitas peças contemporâneas (em Sept Papillons [de Kaija Saariaho] é o maior desafio, por exemplo), e envolve um estudo focado na técnica expandida, o que significa, em muitos momentos, negar a técnica convencional que pratico há tantos anos, treinar as mãos para outras possibilidades. Por conta da técnica convencional, muitas vezes a

62 Breu é uma resina que é aplicada nas cerdas do arco, para que haja atrito entre elas e as cordas e, assim, vibração. 
altura das notas que eu tocava - partindo da partitura gráfica - era previsível, os intervalos consonantes, o som muito limpo e com pouco ruído, os glissandos constantes, o que deixou a música enfadonha. (AIROLDI, 2019, p. 63)

Uma das formas de desdoutrinar a técnica no violoncelo, segundo Silvio, seria através do glissando: fazê-lo torto, passando de um dedo a outro e parando em lugares aleatórios; ou fazê-lo com curvas distintas - em um glissando ascendente, em vez da curva tradicional exponencial (mudança de altura começa lenta e acelera), uma curva linear, por exemplo. Outra forma seria estudar fragmentos que passassem por escalas e notas não ressonantes no violoncelo, para fugir da sua ressonância habitual nas notas ré e sol.

Outra sugestão de Silvio, para a performance, foi mapearmos quais gestos instrumentais eram próximos, e quais eram distantes, para evitar, durante o espelho, que eu fizesse uma sequência de símbolos impossível de ser feita instantaneamente no violoncelo - como, por exemplo, passar de um tremolo a um pizzicato Bartók. Tal mapeamento diminuiria, também, os silêncios truncados, as fragmentações do fluxo. No encontro seguinte à reunião (8 de maio), elaboramos tal mapa de proximidade dos gestos, a partir da técnica de Giovanna ${ }^{63}$, disponível na figura 36.

Ainda outra questão da reunião com Silvio Ferraz, no dia 7 de maio, foram os materiais. Como já disse, vimos que a performance do espelho era um tanto inviável com tinta aquarelável, nanquim e papel de arroz. É como Silvio nos disse na ocasião: a escolha do material vem pelas necessidades do que vamos fazer. Se precisávamos de agilidade e um tempo longo entre carregamentos de tinta, deveríamos mudar de material. Aliás, era necessário também mudar um pouco a relação com o espaço: em vez de nos preocuparmos em não sujar de tinta o espaço da performance, proteger o chão com algum plástico ou lona, para liberar os gestos.

E foi o que fizemos. No dia 22 de maio Giovanna e eu nos encontramos na Praça do Relógio, em um caminho pavimentado a céu aberto um pouco atrás do Departamento de Artes Cênicas da ECA-USP, para que não houvesse problemas com os respingos de tinta ${ }^{64}$. Ali, testamos novos materiais que ela havia trazido: alguns tipos de tecido, pincéis maiores e brochas, além de outras tintas (acrílica solúvel em água e pigmentos). Precisávamos de um pincel que suportasse mais tinta e água; de uma tinta que fosse pigmentada mas fluida, para que pudéssemos diferenciar os gestos; e de um tecido "que permitisse que a tinta corresse, sem impermeabilizá-la nem absorvê-la por completo, para que o desenho não se desfigurasse”. (AIROLDI, 2019, p. 64)

${ }^{63}$ É importante salientar que o mapa da figura 36 foi feito a partir da técnica e do repertório de Giovanna Airoldi. Assim, embora ele possa ser usado em processos com outras pessoas, as/os instrumentistas devem sempre ser, no mínimo, consultadas/os.

${ }^{64}$ É relativamente comum ver experimentos e mesmo trabalhos visuais nos caminhos da Praça do Relógio, especialmente na região próxima aos departamentos de artes da ECA-USP. 


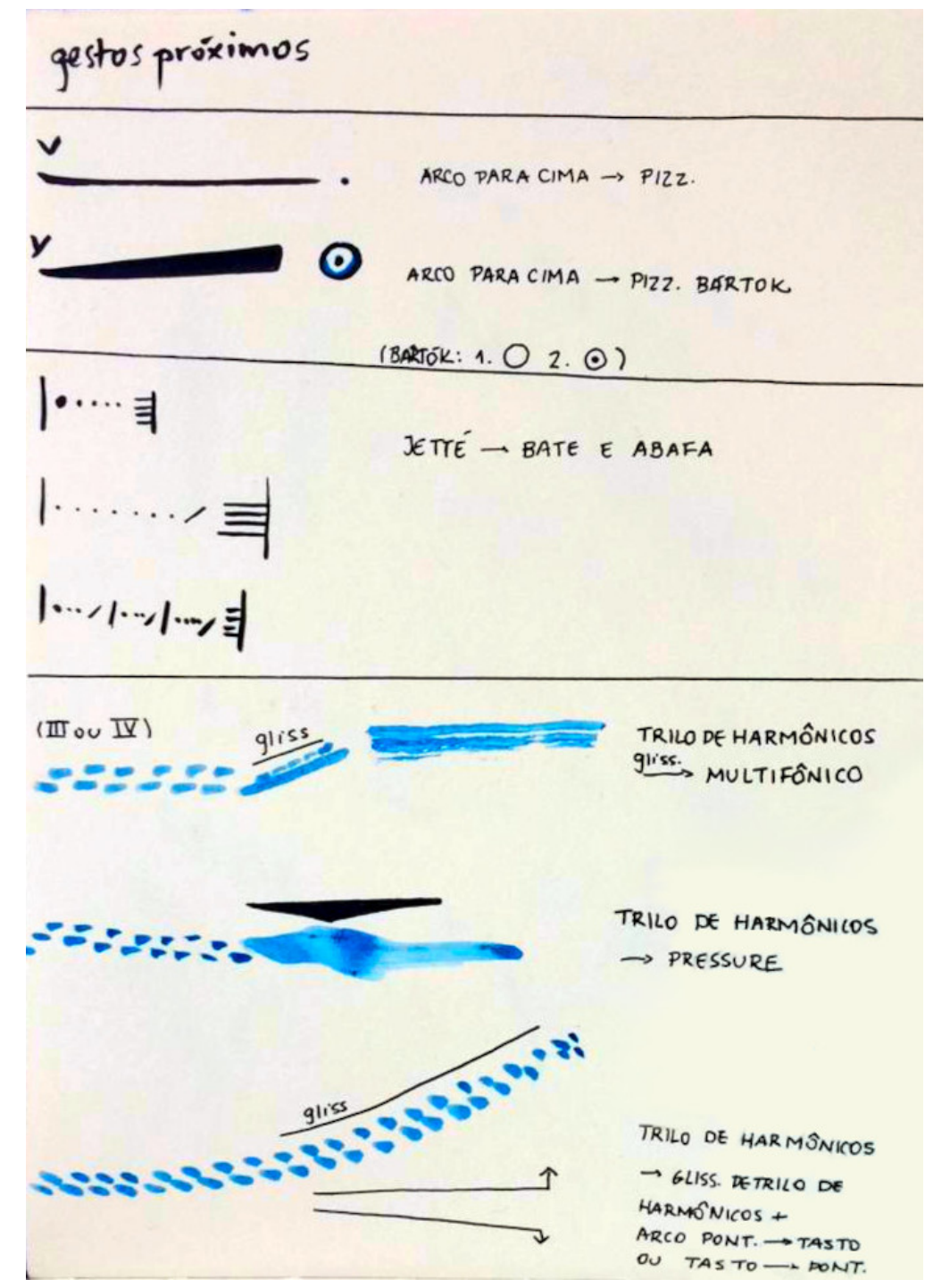

Figura 36: Mapa de gestos instrumentais próximos no violoncelo, a partir da técnica e repertório de Giovanna Airoldi, elaborado em encontro do dia 8 de maio de 2019.

Depois dos testes, experimentamos novamente o espelho. Apesar das dificuldades impostas pelo espaço a céu aberto - vento, sons de cortadores de grama e trânsito, e mesmo o risco de chuva -, pudemos perceber que aqueles novos materiais eram adequados ao que queríamos, porque permitiam que os gestos fossem rápidos, incisivos, amplos, longos etc. Mas, exatamente por isso, vimos também que a superfície que eu pintava precisava ser maior.

Porém, se os problemas com os materiais estavam resolvidos (ou pelo menos encaminhados), outras questões permaneciam. Os símbolos ainda não eram os melhores, geravam interrupções e confusões na performance; e, de todo modo, eu continuava a não ser violoncelista e, com isso, a gestualidade instrumental de Giovanna ainda era distante para mim - embora a continuidade da prática do espelho, ao longo dos encontros, estivesse ajudando nisso.

Para entender melhor esses dois problemas, experimentamos inverter os papéis no espelho. No encontro do dia 31 de maio, eu toquei violoncelo e Giovanna pintou, o que trouxe dois desenvolvimentos importantes ao processo. Primeiro, compreendemos na 
prática as dificuldades um do outro - dela, de entender quais símbolos eu pintava; e minha, de espelhar seus movimentos na mesma velocidade. E depois, através desse mergulho no outro lado do espelho, pudemos enxergar os problemas de outros ângulos - como fazer um desenho, refleti-lo no espelho e com isso ver detalhes e proporções que o hábito escondeu.

As mudanças: o azul seria o uso do arco (o pincel era o arco); o preto seria o pizzicato, pintado diretamente com os dedos (como os dedos nas cordas), se mão esquerda, pizz. de mão esquerda, e vice-versa; o ângulo do pincel em relação ao tecido seria o ponto de contato (sul ponticello, ordinario, sul tasto); e o símbolo para o pizz. Bartók seria apenas um círculo (sem o ponto). Ou, em resumo: os símbolos deixaram de ser apenas marcações no tecido, e passaram a incorporar a gestualidade de quem pinta.

Se fôssemos fazer uma nova bula de símbolos, semelhante à figura 32, dessa vez teríamos que desenhar mãos, pincéis e seus movimentos. Aos poucos, ao longo do processo, a relação deixou de se dar apenas entre música e desenho (ou entre som e cor) e passou a envolver o tocar e o desenhar. Ou, para usar o conceito de espaço háptico, presente na monografia de Giovanna, o processo caminhou cada vez mais para um "lugar em que todas as faculdades de percepção se mesclam, e o olho ouve tão bem, ou melhor, do que o ouvido, e o ouvido vê tão bem, ou melhor, do que o olho"; e agora ainda mais: onde o gesto, o movimento do corpo ouve e vê tão bem quanto o olho e o ouvido se movimentam. (FERRAZ, 2007, p. 12)

No dia 17 de junho de 2019, experimentamos todas essas mudanças na sala 21 do Depto. de Artes Cênicas da ECA-USP, usando uma lona branca e um plástico embaixo do tecido e maiores do que ele, para proteger o piso da tinta. Fizemos dois espelhos, disponíveis ${ }^{65}$ na figura 37 e em https : / youtu . be/U4U5gXkAm-I e https : / / youtu . be / X8EQC9ae-3w (acesso em 19 nov. 2020). Como Giovanna diz em sua monografia, foi a primeira vez que o espelhamento foi fluido: por meio da prática ao longo do processo, havíamos internalizado o procedimento ${ }^{66}$; os problemas técnicos não derrubavam mais o fluxo, fosse porque estivessem resolvidos, ou porque já sabíamos lidar melhor com eles - eu conseguia manipular melhor os pincéis e espelhar os gestos de Giovanna, e ela, por sua vez, não se sentia mais em um improviso sem saber o que fazer. Ela inclusive propôs espelhar meu gesto de bater o excesso de tinta do pincel, batendo o arco nas cordas. Nossa atenção estava mais disponível:

por termos nos aprofundado nela [na performance] ao longo do processo, pudemos nos focar apenas na performance em si e em sua construção naquele instante. Isso permitiu que nos tornássemos mais atentos aos movimentos, sons, respiração e expressões um do outro, logo, mais precisos no espelhamento. (AIROLDI, 2019, p. 67)

${ }^{65}$ No segundo vídeo do dia 17 de junho de 2019, ocorreu um problema técnico: a câmera caiu do suporte durante o registro. Ainda assim, o áudio continuou a ser gravado.

${ }^{66}$ Tomo aqui, de forma livre, a concepção de procedimento que aprendi em processos teatrais: um conjunto simples de regras que definem um jogo aberto. 


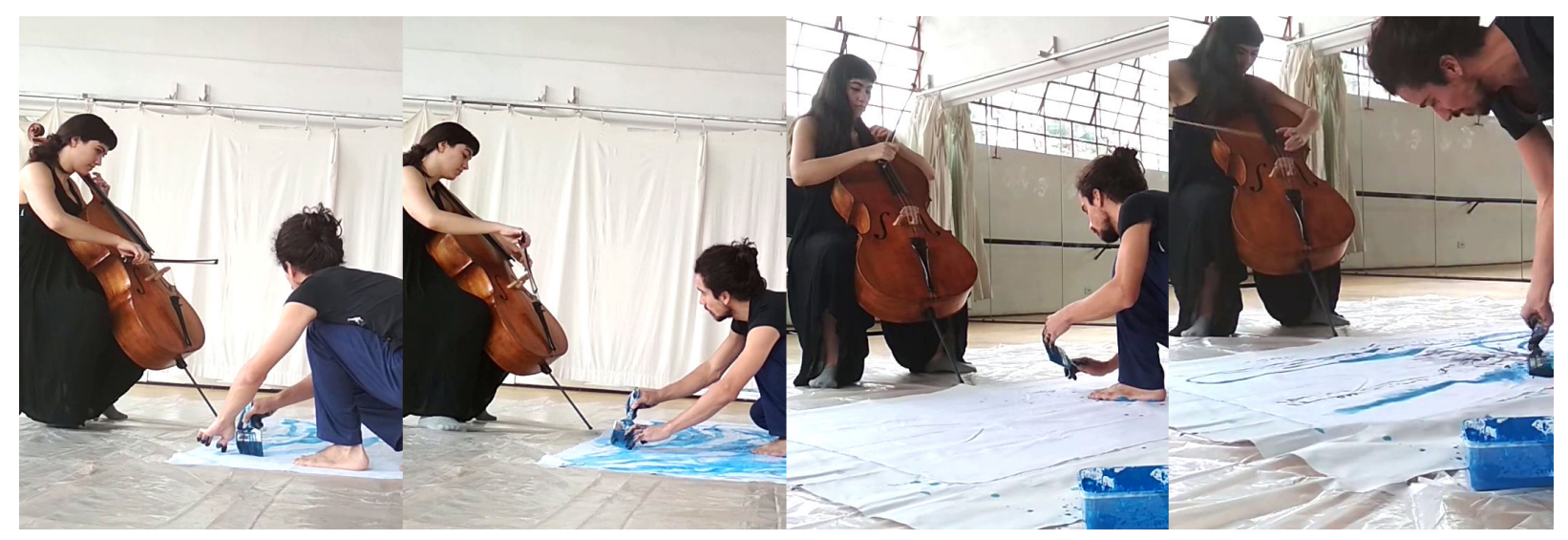

Figura 37: Dois espelhos depois de mudanças nos materiais e símbolos, em quatro momentos, na sala 21 do Depto. de Artes Cênicas da ECA-USP. Disponíveis em https : //youtu . be/U4U5gXkAm-I e https: //youtu . be/X8EQC9ae-3w (acesso em 19 nov. 2020).

Uma ressalva ao que acabei de dizer: embora Giovanna não se sentisse mais improvisando - como ela diz em sua monografia (AIROLDI, 2019, p. 66) 一, o procedimento do espelho contém um elemento chave da improvisação: nunca se sabe $o$ que vai acontecer (como também é dito na mesma página citada da monografia). Não há como saber precisamente qual o próximo gesto da pessoa que você espelha, nem como o seu próprio gesto vai ser espelhado por ela. O espelho como procedimento se aproximava, sem que soubéssemos naquele momento, das práticas da Composição Instantânea (Instant Composition) — do bailarino e coreógrafo britânico Julyen Hamilton, expoente da chamada "nova dança americana" -, em que a performance acontece e é criada ao mesmo tempo:

Na composição instantânea, por fim, o que parece ser importante é o bailarino atualizar-se o tempo todo. Um grande desafio e trabalho de corpo e mente. É possível sempre chegar com uma ótima ideia que pode invalidar-se depois de segundos, quando tudo começar a se mover. (SANTOS, 2017)

Para que o espelho permanecesse vivo, para que a performance respirasse, era preciso respirar com a outra pessoa. Acalmar a vontade intelectual de conceber tudo a todo instante, e respirar juntos. É um pouco (ou muito) o que a diretora teatral Cristiane Paoli Quito disse certa vez, em $2017^{67}$ :

"O improviso é o funeral dos seus desejos".

\subsection{O progresso emaranhado}

nuvens pesadas

fio amarelo de sol

vento de corte

${ }^{67}$ A frase foi dita por ela em um ensaio em que eu participava, no processo da peça Um homem é um homem, da Escola de Arte Dramática da USP. 
Essa sequência toda de páginas, relatos e imagens talvez pareça uma linha contínua, cronológica, ordenada. Linha progressiva, começa em uma conversa, passa por desenvolvimentos consecutivos e consequentes, até por fim atingir um formato final e a tão esperada estreia. Talvez esse e os outros capítulos tragam essa impressão, em parte pelo meu impulso em organizar todas as memórias (físicas e corporais) dos processos - o que foi necessário para escrever -, e em parte pelo desejo por um texto mais fácil de entender.

Se essa linha contínua é o que transparece até aqui, então preciso quebrá-la.

De começo, é possível falar de algo progressivo nesses processos. O problema é que esse progresso não é bem uma linha: é muito mais um emaranhado, encruzilhada de encruzilhadas, de linhas e caminhos que se atravessam, se batem, se torcem e se alimentam. O que seria isso?

Diversas vezes, no processo com Giovanna, chegamos a impasses e a pequenas desistências, a crises que nos punham a pensar "será que é isso mesmo que devíamos fazer?", ou "será que aquele outro caminho não era melhor?", ou ainda "o que é que estamos fazendo?". Crises nesse processo, crises no processo com Jessica (cf. capítulo 3), crises no processo com o grupo de artistas em 2018 e, mesmo depois, sozinho (cf. capítulo 2).

Por exemplo, as crises que tivemos com os materiais, como já disse: as tintas e papéis que eram ótimos para fazer uma partitura gráfica com calma, fora do ambiente da performance, não serviam para o procedimento do espelho. Mudar o material não é simples: aqui, no texto, é uma questão de um ou dois parágrafos, mas na prática envolve pesquisá-los em lojas diferentes, experimentá-los, arriscar combinações incomuns, e, por fim, envolve uma reorganização do corpo na performance. Se com o papel de arroz eu permanecia sentado ou ajoelhado durante o espelho (cf. figura 35), com o tecido grosso era preciso pisá-lo, sem perder o equilíbrio nem curvar demais a coluna, e ainda assim alcançar o chão com as mãos e o pincel (cf. figura 37).

Tanto é assim que na reunião já citada com Silvio Ferraz, no dia 7 de maio, os dois caminhos estavam em aberto: o procedimento do espelho ou usar uma partitura gráfica anterior à performance; aliás, o espelho era uma possibilidade que víamos como praticamente descartada, já que até ali tínhamos conseguido pouquíssima fluidez no procedimento.

Outro exemplo: antes do encontro do dia 17 de junho, em que alcançamos uma boa fluidez no espelho, sentíamos que algo faltava ao procedimento. Foi assim que no dia 31 de maio - quando invertemos os papéis do espelho - , Giovanna propôs que desenhássemos o fluxo geral da peça antes do procedimento em si, no mesmo tecido que eu pintaria, ficando visível ao público. Esse fluxo nos ajudaria a saber, bem grosso modo, por onde ir, quando parar etc.; mas, além disso, havia também outra intenção: 
não existe ali alguém que compõe (Neto) e alguém que executa (eu), ou alguém que toca (eu) e alguém que transcreve (Neto), e sim uma música que é criada por ambos, que tentam se espelhar, no momento em que a performance acontece. Quando eu manipulo pincéis e tintas antes de me sentar para tocar o violoncelo, demonstro que ambas as faces do espelho pertencem a mim, e também ao Neto. (AIROLDI, 2019, p. 65)

Naquele dia, desenhamos alguns fluxos possíveis para a performance, disponíveis na figura 38. Mas no encontro do dia 17 de junho nos esquecemos dessa etapa, desenhar o fluxo antes do espelho. Chegamos a retomá-la em outro encontro, na semana seguinte (que infelizmente não foi registrado), mas, como relato mais adiante sobre o recital de Giovanna, nos esquecemos dela novamente no dia da estreia.

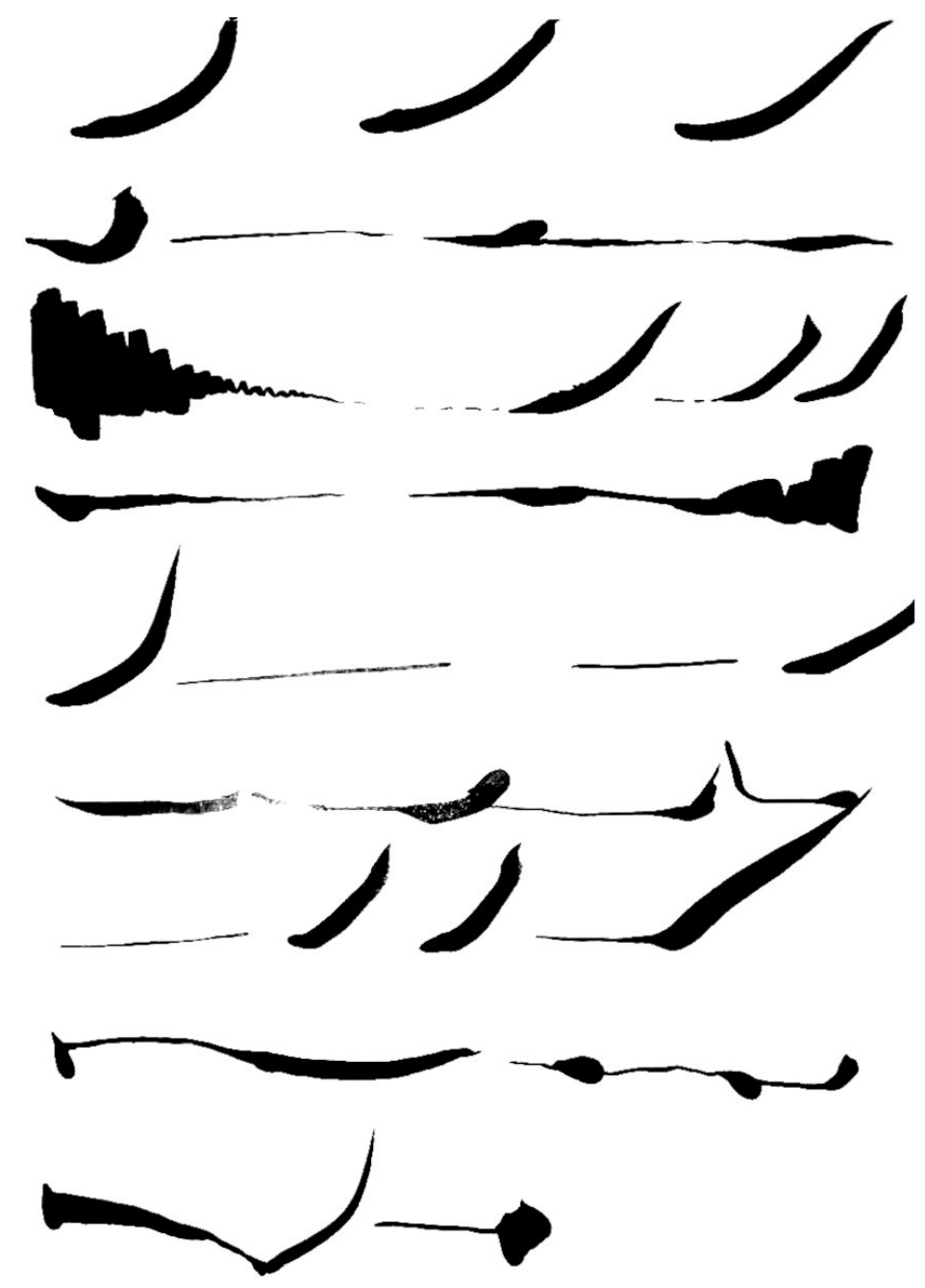

Figura 38: Desenhos de fluxos possíveis para a performance, feitos no dia 31 de maio. Cada "sistema" é um fluxo distinto.

Outras duas mudanças que não se repetiram depois de feitas. No dia 7 de junho, registrado apenas em áudio, experimentamos fazer o espelho entre violoncelos: ambos tocávamos violoncelos - embora, obviamente, minha falta de técnica me atrapalhasse bastante. Sentados de frente um para o outro, a uma distância de dois metros aproximadamente, espelhávamos os movimentos um do outro. Conseguimos um fluxo sonoro interessante; porém, o desenho deixou de participar ativamente do procedimento, o que era um problema para nós. 
Segunda mudança não repetida: experimentamos mudar novamente os materiais, dessa vez com pastel colorido sobre um papel liso e opaco. Como não havia tinta, o movimento de carregá-la no pincel, que até aquele momento era ainda um problema não resolvido, não acontecia. Porém, sentíamos necessidade da tinta, apesar de suas dificuldades.

Crises, pequenas ou grandes. Onde podíamos fazer os encontros? Precisávamos de um lugar com espaço suficiente, com piso plano e não muito delicado, com uma acústica interessante e sem muitos sons externos - onde? Os encontros aconteceram em salas do Depto. de Artes Cênicas (que satisfaziam todos os critérios mas dificilmente estavam disponíveis), do Depto. de Música (pequenas e com muitos sons de fora); na Praça do Relógio (em que acústica e outros sons atrapalhavam); e até mesmo na sala do apartamento onde moro, no Conjunto Residencial da USP (pequena, sem isolamento nem boa acústica, mas com piso aceitável). Diversas vezes remarcamos os encontros devido à falta de espaço apropriado para o que havíamos planejado.

Um processo fragmentado. É possível falar de algo progressivo, com tantas descontinuidades? Mas, supor que o progresso é um processo contínuo requer descartar as crises, negar sua existência - o que, isso sim, me parece impossível, já que essas descontinuidades são inerentes a um processo progressivo.

$$
\begin{aligned}
& \text { Não há processo de formação contínua. (...) em muitos casos, e em } \\
& \text { particular no trabalho, é impossível progredir de maneira monolítica } \\
& \text { (...). Todo processo construtivo é um processo que não é unicamente } \\
& \text { o correr adiante, mas também o retornar, o construir e o acoplar, o } \\
& \text { tecer. }{ }^{68} \text { (SIMONDON, } 2015, \text { p. } 387,389-390 \text {, tradução minha) }
\end{aligned}
$$

Mais ainda, as crises não só fazem parte do processo, como ajudam a colocá-lo em movimento. Esses momentos, em que deixamos algumas coisas e caminhos de lado e focamos em outras, tais momentos definem ciclos. Desaceleração, um quase parar das atividades, um colocar entre parênteses o que já não se adequa, um guardar para depois. Desaceleração, ciclo. As crises, em realidade, não geram esse frear, essa degradação, essa perda de potência, as crises a manifestam, por mostrarem a necessidade de uma reorganização em bases mais modestas, como nos fala o filósofo Gilbert Simondon (2015, p. 390-391).

Cada um dos problemas que citei há pouco - com os materiais, com o esquecimento de etapas planejadas, com propostas que não abarcavam as questões do processo, com espaço para os encontros - gerou uma desaceleração de nossas atividades, por um lado, mas por outro nos levou a caminhos que não prevíamos. Lidar com a falta de espaço, por exemplo, nos fez ensaiar em uma praça, o que nem eu nem Giovanna havíamos feito até então. A leveza e fluidez da tinta aquarelável no papel de arroz permaneceu, de certa forma, nos gestos com tinta acrílica diluída sobre o tecido. E

${ }^{68}$ Il n'y a pas processus de formation continue. (...) dans beaucoup de cas, et en particulier dans le travail, il est impossible de progresser de façon monolithique (...). Tout processus constructifest un processus qui n'est pas uniquement le fait de courir devant, mais qui est aussi le fait de revenir, de construire et d'atteler, de tisser. 
mesmo as propostas esquecidas ou não repetidas nos levaram, quando feitas, a uma maior internalização do procedimento do espelho.

Quebrada a linha contínua que esse relato poderia aparentar, pergunto: como fica o espelho com público?

\title{
4.5 O espelho, aberto
}

\author{
pitanga cheia \\ frio de primavera em flor \\ quase no fim
}

O espelho já estava fluido. Alcançamos em torno de dez minutos nas duas vezes que o experimentamos no dia 17 de junho (cf. figura 37). Precisávamos, porém, internalizá-lo ainda mais, para que conseguíssemos tanto uma duração menor - condensando as intensidades da performance - como uma atenção maior no espelhamento, já que o Recital de Conclusão de Curso de Giovanna se aproximava, trazendo consigo o desafio de manter aquela atenção frente ao público.

Foi assim que fizemos um último encontro antes da estreia, que infelizmente não foi registrado ${ }^{69}$, entre 24 e 26 de junho de 2019 em uma das salas de ensaio do Depto. de Artes Cênicas da ECA-USP. Ali, conseguimos combinar práticas e propostas de momentos diversos do processo: fizemos um aquecimento, semelhante ao do dia 24 de abril (cf. figura 34) mas mais curto; desenhamos um fluxo geral da performance antes do espelhamento, como Giovanna havia proposto em 31 de maio (cf. figura 38); e fizemos o espelho. Correndo o risco de exagerar na lembrança, já que ela é o único registro que tenho nesse caso, me lembro de que aquela foi a melhor realização que fizemos do procedimento: estávamos tranquilos e atentos, devido ao aquecimento, e alcançamos uma concisão da performance, graças ao desenho anterior do fluxo geral.

Naquele encontro (ou talvez antes), a performance ganhou um nome: Azul. Cor importante para Giovanna em seus desenhos, e presente durante todo o processo.

Aqui, antes do recital, uma interferência de outro processo. Como relato na seção 2.6, no capítulo 2, em 27 de junho de 2019 (na véspera do recital de Giovanna) participei do Sarau Vozes Inauditas, no Instituto de Artes da Unesp, com a performance Respire - que na época havia sofrido muitas mudanças a partir do processo com Giovanna. Eu havia escolhido, como figurino para a ocasião, uma roupa que me desse flexibilidade e fosse inteiramente branca, para que ficasse manchada ao longo da performance (com carvão de desenho, cf. figura 10).

${ }^{69}$ Esse encontro também não faz parte do relato de Giovanna em sua monografia, já que ocorreu depois que ela a havia enviado para a banca de avaliação. 
Ocorre que Giovanna e eu decidimos um figurino idêntico para mim: branco, enquanto ela usaria preto. Tal decisão, que aconteceu depois da equivalente no processo de Respire, foi influenciada por tal processo, já que cada vez mais víamos como interessante o fato de eu terminar o procedimento com os pés e mãos sujos de tinta (cf. vídeos da figura 37), e uma roupa branca ampliaria isso. E, como não dispunha de outra calça branca apropriada, usei a mesma tanto no sarau na Unesp como no recital de Giovanna. Limpei como pude as manchas de carvão, mas não havia tempo viável para lavá-la completamente, de modo que as manchas permaneceram na performance de Azul.

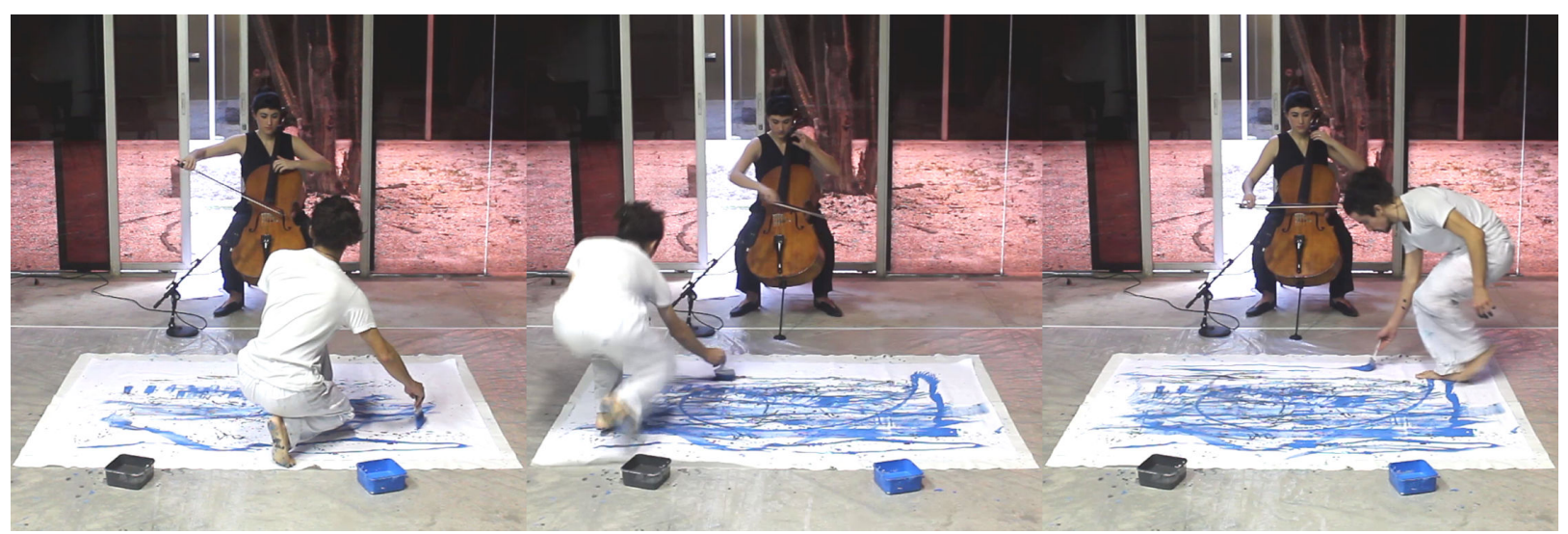

Figura 39: Registro da estreia de Azul no Espaço das Artes, no dia 28 de junho de 2019, no Recital de Conclusão de Curso de Giovanna Airoldi. Disponível em https : //youtu . be/iMSDm6I-jUk (acesso em 22 nov. 2020). Vídeo, captação, edição e mixagem: Guilherme Ribeiro (Gravemus).

No dia 28 de junho de 2019, aconteceu o Recital de Conclusão de Curso de Giovanna, na Sala de Música do Espaço das Artes da ECA-USP, de manhã. Azul foi a última performance, com registro disponível na figura 39 e em https : / y o u tu . be / iMSDm6I-jUk (acesso em 22 nov. 2020). Ela aconteceu depois das outras peças do recital: Sonata para violoncelo solo (1955), de George Crumb; À deriva (2009), de Marisa Rezende; Cinco Mo(vi)mentos (2012), de Alexandre Ficagna; e Sept Papillons (2000), de Kaija Saariaho. Devido a isso, e a problemas técnicos que antecederam o início do recital, não pudemos fazer um aquecimento juntos para o espelho; e também nos esquecemos de desenhar o fluxo geral da performance no seu início. Mais do que isso, o desafio para Giovanna de tocar um repertório solo variado e com inúmeras dificuldades técnicas, combinado à ansiedade de ser avaliada por uma banca, tornou o procedimento da performance ainda mais desafiador.

Por outro lado, o processo de Azul fluía também por outros momentos daquele recital: durante todas as peças citadas, um projetor exibia, no tecido (ainda branco) que usaríamos no espelho, desenhos feitos por Giovanna. Essa ideia havia surgido em um dos encontros, e a desenvolvemos até o dia da apresentação. Além disso, sendo o objetivo da pesquisa dela "colocar a imagem visual e a imagem sonora em um mesmo espaço de compreensão" (AIROLDI, 2019, p. 14), e tendo sido o repertório do recital escolhido e estudado a partir dessa premissa, foi estabelecida uma continuidade entre Azul e as outras peças - ainda mais porque em Sept Papillons, a peça que a antecedeu, a 
presença e a gestualidade do corpo também são muito importantes: através dos sons e dos gestos, surgem imagens (sonoras, visuais) de borboletas.

Mas a estreia não encerrou o processo.

\subsection{O correr das linhas}

No segundo semestre de 2019, não pudemos continuar o processo de Azul, devido a dificuldades de agenda tanto de Giovanna como minhas. Chegamos a escrever e enviar um projeto para o Programa de Ação Cultural (ProAC) do Estado de São Paulo, em que incluímos Azul, a peça Mirante (cf. capítulo 3), além de peças do repertório de Giovanna; mas infelizmente não fomos selecionados.

Pretendíamos retomar os encontros em 2020: focaríamos em aprofundar o procedimento do espelho, tanto através de práticas corporais advindas das artes cênicas, e através da prática do desenho com os materiais, como com ideias trazidas da Instant Composition de Julyen Hamilton, como abordada por Santos (2017). Mas, devido à pandemia de Covid-19 e seu consequente isolamento social, não pudemos fazer essa retomada.

Apesar disso, o processo não ficou completamente parado. No segundo semestre de 2020 - depois de uma paralisação quase total das minhas atividades no começo da quarentena - , pedi a Giovanna que me enviasse um retorno sobre o processo. Não tanto uma reflexão teórica (ainda mais porque ela já a havia feito em sua monografia), mas uma percepção, uma sensação a partir do processo, que poderia ser um texto, um desenho...

Fazer isso foi uma retomada do processo de Azul, não tanto no procedimento do espelho, mas em uma prática do desenho a partir da sua conexão com a prática musical. Em 2020, Giovanna já vinha desenvolvendo uma experimentação nesse sentido: como seria criar, no desenho, uma defasagem de linhas? Através da exploração da transparência, tanto com papel vegetal como com acetato, criar uma defasagem não-temporal, visual. Uma sobreposição de fluxos. A figura 40 mostra algumas de suas experimentações, passando por símbolos e gestos visuais provenientes do processo de Azul (por exemplo, o pizzicato Bartók, círculo com ponto no centro, presente no terceiro desenho).

A partir desses desdobramentos de Azul, propus a ela: ao ouvirmos uma música com o instrumento que tocamos, nosso corpo responde, sensações surgem, semelhantes às do momento da performance. Como seria, então, desenhar a partir dessas sensações? Associando isso à defasagem de linhas com transparência, Giovanna fez outro experimento, no início de outubro de 2020 , e registrou parte desse processo, como pode ser visto na figura 41 e em https: //youtu. be/8iS8KdSrY3M (acesso em 23 nov. 2020). Nele, ela retomou os símbolos gestuais que havíamos desenvolvido, mas com 

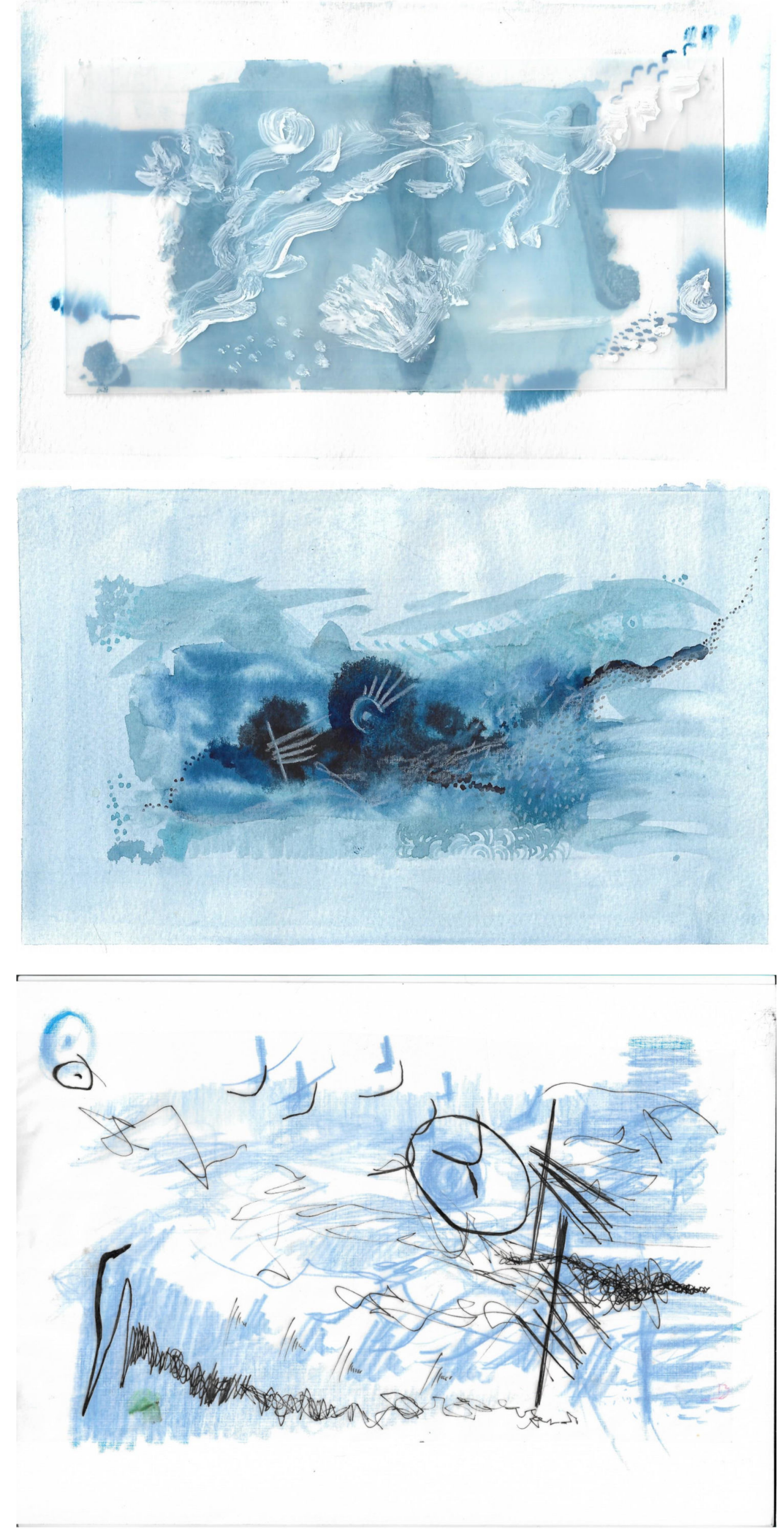

Figura 40: Três defasagens com transparência, feitos por Giovanna como retomada do processo de Azul no segundo semestre de 2020. 


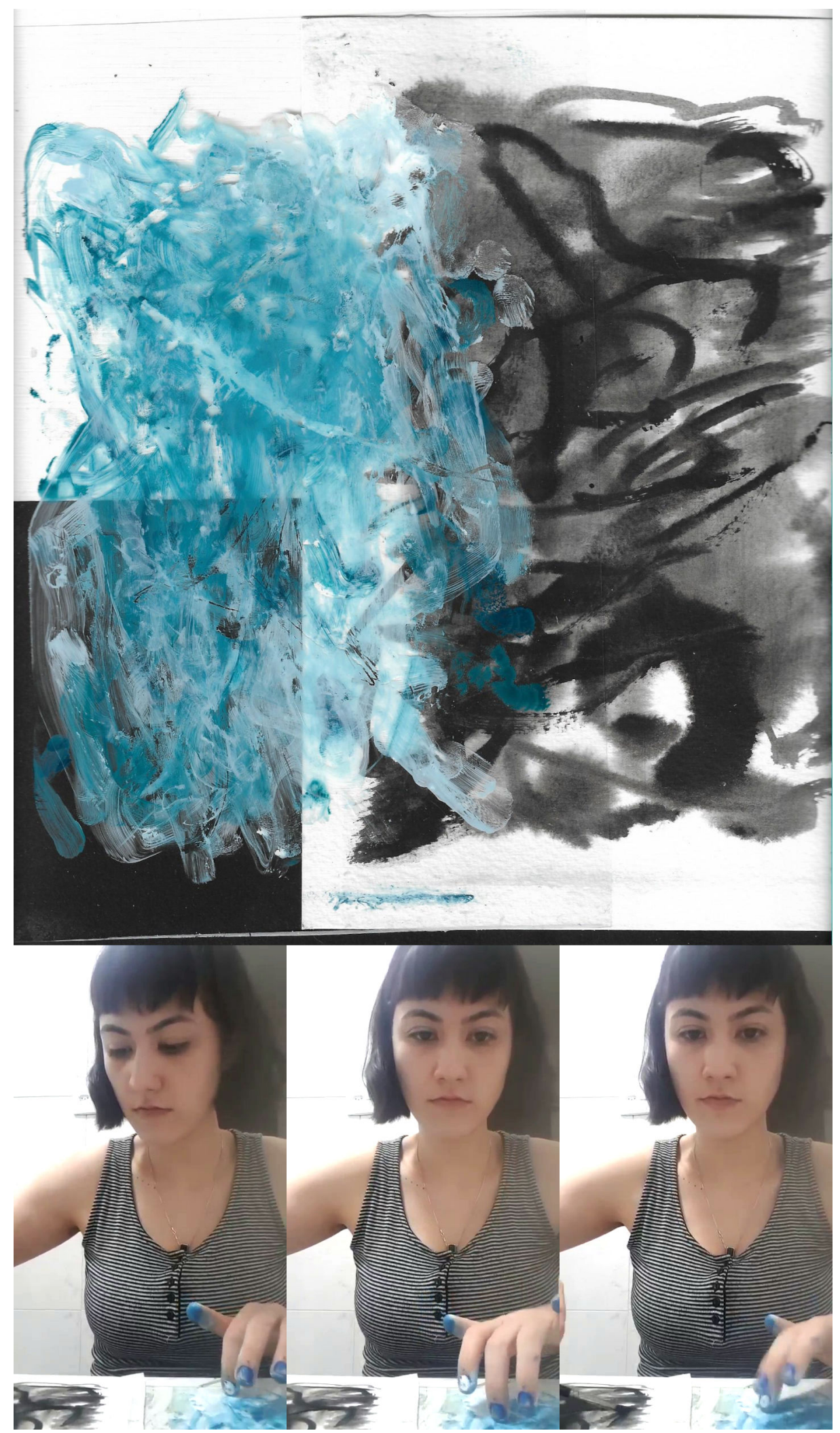

Figura 41: Experimento de defasagem/gestualidade e pequeno registro, feitos por Giovanna no início de outubro de 2020. Registro disponível em https : //youtu . be/8iS8KdSrY3M (acesso em 23 nov. 2020).

cores invertidas: a mão direita, do arco, é feita com pincel e tinta preta sobre o papel; e a mão esquerda, nas cordas, é feita com os dedos diretamente no acetato e tinta azul.

Ao comentar esse experimento, em um áudio de conversa por rede social em 4 de outubro de 2020, Giovanna acabou refletindo sobre o processo de Azul. Com 
a permissão dela, transcrevo esse áudio a seguir, tentando manter o ritmo e as repetições, pausas e retornos da fala.

Fazer isso, de reviver o processo e tentar desenhar, nossa, eu percebi muitas, muitas coisas, como esse processo, a Azul, foi muito importante pra mim, como mudou...é louco isso, mas mudou completamente a minha maneira de me relacionar com... com a música no geral, sabe? Porque, apesar de eu sempre desenhar e de eu flertar com a música experimental, eu nunca tinha conseguido unir essas coisas e... e abriu o meu jeito de fazer música... assim, pra sempre. É um negócio muito louco. E as camadas vão se sobrepondo. Então eu achei, achei interessante essa... esse jogo da camada, porque ela não é só musical, ela também é... são as camadas da construção do... do meu fazer musical, sabe? Realmente foi um negócio muito, muito... potente.

Giovanna Airoldi

Azul também mudou a minha relação com a música, o desenho e a performance. Se é verdade que já vinha pesquisando a interseção entre essas três áreas desde 2018 (cf. capítulo 2), foi com esse processo que de fato tive coragem para juntá-las no mesmo momento, no palco. Como já disse, isso influenciou diretamente o processo da performance Respire, como relato melhor no capítulo 2; e depois, em processos de outras peças (como Voo lento, de 2019, e Sopro pequeno, de 2020), assumi mais diretamente o desenho como parte do processo composicional. Não tanto uma etapa fixa, constante; muito mais próxima do que diz Silvio Ferraz (FERRAZ, 2007, p. 11): "O desenho traz sempre o frescor de um novo lugar de encontro".

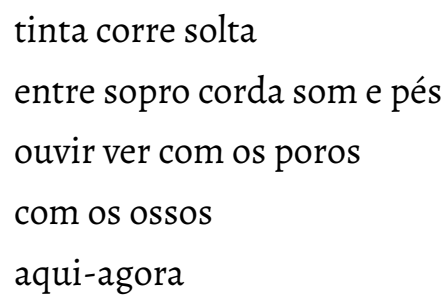

Se sua leitura fez o salto que sugeri no capítulo 2, continue a partir da seção 2.6. 


\title{
5 UM PEQUENO SOPRO
}

\author{
encontrar o mar \\ de ondas rugir fundo \\ embaixo da pele \\ encontrar o vento \\ sopro de folhas penas \\ vozes olhares \\ abrir os olhos \\ ouvir o deserto vasto \\ de povos imagens \\ compor \\ habitar o encontro \\ brotar das vozes \\ compor \\ povoar o deserto \\ ouvir imagem
}

Nos processos criativos de que falo nessa dissertação, uma preocupação foi

relativamente constante. Trazer as unicidades das vozes envolvidas, suas potências, suas linhas diversas, no desenrolar dos encontros, ensaios, e mesmo no momento de um trabalho mais solitário, como fazer uma partitura ou planejar uma performance.

As unicidades estão sempre lá, nas vozes-corpos que movem os processos; mas é preciso colocá-las em evidência para que elas sejam de fato condutoras do processo. Para falar com Cavarero (2011), já que a razão da filosofia ocidental, ao longo dos séculos, tentou desvocalizar a palavra, a fala, a linguagem verbal, colocar agora a unicidade das vozes em evidência - isso que sabemos e sentimos sempre, embora talvez ignoremos: que toda voz é única, e que é na relação com outras vozes que essa unicidade acontece.

Vocalizar a palavra, vocalizar a composição, vocalizar a prática musical: se o que ouvimos como música é sempre alguém tocando (cantando, mixando etc.), como nos diz Cook (2006), colocar a unicidade dessa voz em evidência. A voz dessa entidade que surge entre performer e seu instrumento, ou entre vários; essa unicidade, que por ser voz modifica nossa presença no espaço - para falar com Böhme (2014) — e que está sempre mudando, é sempre transitória.

Por essa unicidade ser transitória, percebi, ao longo da pesquisa, que o termo não seria bem trazer as unicidades, mas muito mais deixá-las aparecer nos processos. Abrir 
espaço para que elas possam surgir, e escutá-las atentamente. E nesse abrir espaço, surge a ideia do encontro. Esse entre, a dupla captura de Deleuze e Parnet (1998), algo que passa entre dois, entre muitos, e que não é uma construção, uma elaboração, não é uma autoria conjunta. Como aqueles autores dizem, não é o encontro entre dois mundos, porque esses mundos já são eles mesmos definidos pelos encontros. Em vez de construir unicidades, deixá-las aparecer nas suas muitas linhas e direções.

Algo como deixar as vozes surgirem, quebrar as amarras que as prendem - a corpos predefinidos, a estéticas e vozes estabelecidas, a uma pretensa coerência do ser. Vozes que surgem no deserto, geografia de linhas sem começo nem fim - porque, afinal, quando começa e quando termina um processo? Onde começa e onde termina a minha parte em cada processo? Sempre no meio, no encontro. Como na abordagem de Paula Molinari (2013). A cada pequena amarra que se desfaz, a cada voz que brota, abrir a escuta a esse universo múltiplo.

Um universo que não é feito apenas de sons, porque não vivo o mundo apenas pelo ouvido. Abrir a prática musical também ao que não é som propriamente, aos movimentos, às cores, às linhas e manchas... à vida dos olhares... e não perder os sons. Atravessá-los com o que não ouço com o ouvido. Também aí, fazer sonoras as forças não sonoras, para falar com Silvio Ferraz (2012).

Trabalhar a composição para que ela aumente a potência do trabalho das outras pessoas: nesses processos, isso só foi possível abrindo aquele espaço, me abrindo aos encontros. Elaborar partituras ou planos, para com eles alcançar uma música que respira, que nos faz respirar, como diz Ferraz (2014). Escutar o que surge disso, sentir onde a respiração está truncada, onde a garganta se fecha e tropeça. Onde e quando preenchemos demais o vazio, de modo que ele perdeu sua potência de fazer surgir algo novo, para falar com Brook (2000). Em que momentos a elaboração se torna visível, presente demais, e deixamos de respirar juntos, para colocar Yoshi Oida (2007) e Ferraz (2014) em conversa.

Reconhecer também que um processo criativo, um processo de formação, não é uma linha contínua. Geografia, ou um correr em ciclos, com suas explosões, suas crises, suas desconstruções - um colocar entre parênteses, um tecer, para falar com Simondon (2015). E perceber, ao encontrar a Pesquisa Artística ${ }^{70}$, que pesquisar arte fazendo arte é também um processo criativo, com suas descontinuidades, suas crises, e a grande dificuldade de comunicar o incomunicável, de falar de um lugar, lugares, em que não há palavras.

Criar um espaço pequenino, em que as vozes muitas possam chegar, se aconchegar, onde elas possam se fazer falar. Criar? Abrir um espaço. Abrir? Com as mãos de muitos desertos, fazer surgir um vazio simples, e nele habitar a cada encontro, a cada ensaio,

70 Desenvolvida aqui a partir de Coessens, Crispin e Douglas (2009), Velardi (2018), Candy e Edmonds (2018), Gil e de Assis (2019), além das aulas de Paula Molinari (2019) em setembro de 2019 na Unesp. 
a cada passagem, a cada conversa, a cada experimento, a cada performance. Exercitar seu caminho como um músculo, um emaranhado de tendões, nervos e músculos, uma prática.

Compor como o mais cotidiano dos atos, fazê-lo simples, não porque não haja técnica, não porque esteja inspirado por deus ou por todos os céus. Mais um dos afazeres de um processo criativo.

Mas com ele encontrar unicidades, encruzilhadas, emaranhados de linhas, vozes outras. Encontrar movimentos, lugares, ideias, imagens, entidades. Encontrar o que não poderia surgir da minha elaboração solitária, chegar ao que não poderia prever. Compor, não para organizar sons ou fluxos, mas para ser lançado num abismo onde reverberam vozes que desconheço.

Para descobrir, a cada vez, que bicho surge. Que bicho é esse que começa a falar entre o sopro, a clarineta e a Chapada dos Guimarães. Descobrir que espelho é esse que ganha vida e se move entre o pincel, o arco e as linhas que se multiplicam. Descobrir que bicho é esse que nasce entre a apneia e a respiração, da voz que estava ali atrás, esperando que as porteiras fossem abertas. Que bicho surge entre as imagens e sílabas de um haicai, entre seus instantes. Jessica, Giovanna, Isadora, Alexandre, Bruna, Paola, Silvio, Paula, Paulo, e tantas outras vozes. Que bicho surge entre.

Fica o desejo de seguir a pesquisa, para mergulhar ainda mais nesse entre, que não é apenas das artes. Ir mais fundo, seguir por mais linhas e caminhos, da filosofia, das artes, das ciências, o que mais foi dito e criado desse lugar. Por exemplo, como fica a ideia de encontro junto com o ritornelo, como abordado por Ferraz (2012)? Ou o que acontece ao colocar a prática musical ainda mais em jogo com outras artes? Se, como diz Ferraz (2014), dois fluxos de energia, lado a lado, sempre se modulam, como fica isso com a unicidade relacional das vozes? E desse encontro, como seguir compondo? Sempre mais encontros, mais vozes.

Brincar com as elaborações, testar e combinar sons e gestos e ideias e conceitos e materiais e imagens, mas sempre em encontro. O processo não é meu, e nem é das outras pessoas. Ele é uma coisa viva, um barquinho a vela que corre pelo sopro de muitos pulmões, e que nos leva a lugares, momentos e movimentos desconhecidos. Basta abrir espaço e soprar. 


\section{REFERÊNCIAS}

AIROLDI, Giovanna Lelis. O desenho como interface partitura-instrumentistacompositor na construção da performance de: Sept Papillon (Kaija Saariaho); À Deriva (Marisa Rezende); Cinco Mo(vi)mentos (Alexandre Ficagna) e Azul (criação colaborativa com o compositor José de Mattos Neto). Trabalho de Conclusão de Curso (Graduação em Música). São Paulo: Escola de Comunicações e Artes, Universidade de São Paulo, 2019.

ARTAUD, Antonin. Cartas desde Rodez. Espanha: Editorial Fundamentos, 1981. v. 1-3. O teatro e seu duplo. Tradução: Teixeira Coelho. São Paulo: Martins Fontes, 2006.

BASHŌ, Matsuo. Trilhas longínquas de Oku. Tradução: Meiko Shimon. São Paulo: Escrituras, 2016. ISBN 978-85-7531-707-5.

BERBERIAN, Cathy. [1966] The New Vocality in Contemporary Music. In: KARANTONIS, P.; VERSTRAETE, P.; SIVUOJA-KAUPPALA, A. (Org.). Cathy Berberian: pioneer of contemporary vocality. Tradução: Francesca Placanica. Farnham: Ashgate Publishing, 2014. p. 47-49.

BIENAL DE SÃO PAULO. Tal Isaac Hadad: Recital para um massagista. $33^{\mathbf{a}}$ Bienal São Paulo [Afinidades afetivas], 2018. Exposição. Disponível em: $<\mathrm{http}: / / 33$. bienal . org. br/pt/agenda-detalhe/5436>. Acesso em: 5 out. 2020.

BÖHME, Gernot. The Voice in Bodily Space. Dialogue and universalism. 2014. v. 24, n. 4, p. 54-61. Disponível em: <https ://www.pdcnet.org/du/content/du_2014_0024 _0004_0054_0061>. Acesso em:29 out. 2018.

BROOK, Peter. A porta aberta: reflexões sobre a interpretação e o teatro. Tradução: Antonio Mercado. Rio de Janeiro: Civilização Brasileira, 2000. 2. ed.

CAGE, John. Silence: lectures and writings. Middletown: Wesleyan University Press, 1961. 10. ed. ISBN 0-8195-6028-6.

CALVINO, Italo. [1986] Um rei à escuta. In: Sob o sol-jaguar. Tradução: Nilson Moulin. São Paulo: Companhia das Letras, 1995. ISBN 978-85-8086-309-3.

CANDY, Linda; EDMONDS, Ernest. Practice-Based Research in the Creative Arts: Foundations and Futures from the Front Line. Leonardo. fev. 2018. v. 51, n. 1, p. 63-69. Disponível em: <https://www.mitpressjournals.org/doi/abs/10.1162/LEON _a_01471>. Acesso em: 9 maio 2020. 
CAVARERO, Adriana. Vozes plurais: filosofia da expressão vocal. Humanitas. Tradução: Flavio Terrigno Barbeitas. Belo Horizonte: Editora UFMG, 2011. ISBN 978-85-7041-850-0.

COESSENS, Kathleen; CRISPIN, Darla; DOUGLAS, Anne Elizabeth. The Artistic Turn: a manifesto. Bélgica: Leuven University Press, 2009. ISBN 978-94-90389-00-0.

COOK, Nicholas. Entre o processo e o produto: música e/enquanto performance. Per Musi. Belo Horizonte, 2006. v. 14, p. 5-22.

DELEUZE, Gilles; PARNET, Claire. Diálogos. Tradução: Eloisa Araújo Ribeiro. São Paulo: Editora Escuta, 1998. ISBN 85-7137-127-X.

DIÁRIO DE PERNAMBUCO (Dir.). As lições de Naná Vasconcelos. Pernambuco: Diário de Pernambuco, 2015. Vídeo. Disponível em: <h t tps : / / y o u tu . be /tvE9YzXoxyQ>. Acesso em: 15 nov. 2018.

EL HAOULI, Janete. Demetrio Stratos: a escuta da voz-música. Dissertação de Mestrado em Ciências da Comunicação. São Paulo: Escola de Comunicações e Artes, Universidade de São Paulo, 1993.

FERNEYHOUGH, Brian. Form-Figure-Style: An Intermediate Assessment. Perspectives of New Music. 1993. v. 31, n. 1, p. 32. Disponível em: <https://www. jstor.org/stable /833034>. Acesso em: 9 out. 2020.

FERRAZ, Silvio. Notas do caderno amarelo: a paixão do rascunho. Tese de Livredocência em Criação Musical. São Paulo: Universidade Estadual de Campinas, 2007. La formule de la ritournelle. Filigrane. 2012. Deleuze et la musique. v. 13. Disponível em: $<$ http://revues.mshparisnord.org/filigrane/index .php?id=420>. Acesso em: 5 out. 2020.

Xie He, composição musical, modulação e ritornelo. Revista Vórtex. 2014. v. 2, n. 2, p. 19-31.

GIL, Susana Castro; DE ASSIS, Ana Cláudia. Pesquisa artística como espacio de decolonización de la producción de conocimiento musical. In: XXIX CONGRESSO DA ASSOCIAÇÃO NACIONAL DE PESQUISA E PÓS-GRADUAÇÃO EM MÚSICA, 2019, Pelotas. Caderno de Resumos e Anais.... Disponível em: <https : //www . anppom . com . br/congressos/index.php/29anppom/29CongrAnppom/paper/view/5641>. Acesso em: 7 nov. 2020.

HOLDERBAUM, Flora Ferreira. A voz-música na intermídia som-palavra-performance. Dissertação de Mestrado em Música. Curitiba: Universidade Federal do Paraná, 2014.

KATO, Shuichi. Tempo e espaço na cultura japonesa. Tradução: Neide Nagae; Fernando Chamas. São Paulo: Estação Liberdade, 2012. ISBN 978-85-7448-202-6. 
MATTOS NETO, José P. De; RAULINO, Lucas. Luthieria: ou como deixar surgir a voz do instrumentista-instrumento. In: XXIX CONGRESSO DA ANPPOM, 2019, Universidade Federal de Pelotas, RS. Caderno de Resumos.... Disponível em: <https : / /wWw . anppom. com.br/congressos/index.php/29anppom/29CongrAnppom/paper /view/5979>. Acesso em: 7 nov. 2020.

MOLINARI, Paula Maria Aristides de Oliveira. Alfred Wolfsohn na obra de Charlotte Salomon: uma cartografia que emerge da voz. Tese de Doutorado em Comunicação e Semiótica. São Paulo: Pontifícia Universidade Católica, 2013. Disponível em: $<\mathrm{http}$ : / /tede2. pucsp. br/tede/handle/handle/4600>. Acesso em: 25 nov. 2020.

Sobre pesquisa artística (anotações de aula). Tópico de aula apresentado em Disciplina de pós-graduação “Tópicos Especiais em Educação Musical: Arte sonora ambiental e/ou ecológica", Universidade Estadual Paulista: Anotações de aula, 18 set. 2019.

OIDA, Yoshi. O ator invisível. Tradução: Marcelo Gomes. São Paulo: Via Lettera, 2007. ISBN 978-85-7636-055-1.

OLIVEIRA, Francisco Zmekhol Nascimento De. A escrita rítmica de Olivier Messiaen e seus desdobramentos em outros aspectos de sua prática composicional. Dissertação de Mestrado em Música. Campinas: Instituto de Artes, Universidade Estadual de Campinas, 2013. Disponível em:<http://repositorio. unicamp.br/jspui /handle/REPOSIP/284520>. Acesso em: 1 nov. 2020.

QUILICI, Cassiano Sydow. Antonin Artaud: teatro e ritual. Portugal: Imprensa da Universidade de Coimbra, 2012. ISBN 978-989-26-0256-1. Disponível em: <https : //digitalis-dsp.uc.pt/jspui/handle/10316.2/38335>. Acesso em: 27 out. 2019.

SANTOS, Maíra Simões Claudino. Composição Instantânea: formação coreográfica do artista da dança e de seu corpo-realidade. Revista Brasileira de Estudos da Presença. 23 out. 2017. v. 8, n. 1, p. 167-193. Disponível em:<http: //www . scielo.br/scielo .php?script=sci_arttext\&pid=S2237-26602018000100167\&lng=pt\&tlng=pt $>$. Acesso em: 16 nov. 2020.

SCIARRINO, Salvatore. Le figure della musica: da Beethoven a oggi. Milano: Ricordi, 1998. ISBN 88-7592-534-8.

. Le son et le silence. In: FERNEYROU, L. (Org.). Silences de l'oracle: autour de l'œuvre de Salvatore Sciarrino. Paris: CDMC, 2020. p. 81-83.

SIMONDON, Gilbert. Le progrès, rythmes et modalités. Critique. 2015. v. 5, n. 816, p. 385-400. Disponível em:<http://www . cairn. info/revue-critique-2015-5 -page-384.htm?ref=doi>. Acesso em: 12 set. 2020. 
STOROLLI, Wânia Mara Agostini. Movimento, Respiração e Canto: a performance do corpo na criação musical. Tese de Doutorado em Artes. São Paulo: Escola de Comunicações e Artes, Universidade de São Paulo, 2009. Disponível em: <http : / /www.teses.usp.br/teses/disponiveis/27/27158/tde-13052009-104317/>. Acesso em: 26 mar. 2016.

VELARDI, Marília. Questionamentos e propostas sobre corpos de emergência: reflexões sobre investigação artística radicalmente qualitativa. MORINGA: Artes do Espetáculo. 26 jun. 2018. v. 9, n. 1, p. 43-54. Disponível em: <http: //www. periodicos .ufpb.br/index.php/moringa/article/view/40646>. Acesso em: 10 maio 2020.

ZUMTHOR, Paul. Introdução à poesia oral. Humanitas. Tradução: Jerusa Pires Ferreira; Maria Lúcia Diniz Pochat; Maria Inês De Almeida. Belo Horizonte: Editora UFMG, 2010. ISBN 978-85-7041-759-6. 